\title{
Report \\ Scaling of Natal Dispersal Distances in Terrestrial Birds and Mammals
}

\author{
$\underline{\text { Glenn D. Sutherland }}^{1}, \underline{\text { Alton S. Harestad }}^{2}, \underline{\text { Karen Price }}^{2}$, and $\underline{\text { Kenneth P. Lertzman }}^{2}$
}

ABSTRACT. Natal dispersal is a process that is critical in the spatial dynamics of populations, including population spread, recolonization, and gene flow. It is a central focus of conservation issues for many vertebrate species. Using data for 77 bird and 68 mammal species, we tested whether median and maximum natal dispersal distances were correlated with body mass, diet type, social system, taxonomic family, and migratory status. Body mass and diet type were found to predict both median and maximum natal dispersal distances in mammals: large species dispersed farther than small ones, and carnivorous species dispersed farther than herbivores and omnivores. Similar relationships occurred for carnivorous bird species, but not for herbivorous or omnivorous ones. Natal dispersal distances in birds or mammals were not significantly related to broad categories of social systems. Only in birds were factors such as taxonomic relatedness and migratory status correlated with natal dispersal, and then only for maximum distances. Summary properties of dispersal processes appeared to be derived from interactions among behavioral and morphological characteristics of species and from their linkages to the dynamics of resource availability in landscapes.

In all the species we examined, most dispersers moved relatively short distances, and long-distance dispersal was uncommon. On the basis of these findings, we fit an empirical model based on the negative exponential distribution for calculating minimum probabilities that animals disperse particular distances from their natal areas. This model, coupled with knowledge of a species' body mass and diet type, can be used to conservatively predict dispersal distances for different species and examine possible consequences of large-scale habitat alterations on connectedness between populations. Taken together, our results can provide managers with the means to identify species vulnerable to landscape-level habitat changes such as forest fragmentation. In addition, our dispersal models can be used to predict which species in a community are likely to be the most vulnerable to loss of connectedness and allow managers to test the merits of alternative habitat conservation plans.

\section{INTRODUCTION}

Distances moved by juvenile animals during natal dispersal are a fundamental element of demography (Arcese 1989), population dispersion, colonization (Hengeveld 1994), and gene flow (Neigel and Avise 1993, Nelson 1993). Despite their ecological importance, dispersal movements are among the least understood attributes of both individual animals and populations. Natal dispersal distances vary considerably among species (Swingland 1982). The frequency of dispersal decreases with increasing distance from the natal area (Taylor 1980, Paradis et al. 1998). Available evidence indicates that short dispersal distances are frequent and strongly influence age and sex structure, abundance, and relatedness within populations. In many species, long-distance dispersal occurs regularly, but at a relatively low frequency. Nonetheless, long dispersal distances are important in invasion and recolonization processes (Shaw 1995) and in the genetic structuring of populations (Ibrahim et al. 1996).

No consensus exists on the factors that determine the distribution of dispersal distances moved by juvenile animals (Paradis et al. 1998). Dominant hypotheses currently used to explain the ultimate benefits of natal dispersal are intrasexual competition for resources (e.g., mates, food, and space) and inbreeding avoidance (Dobson 1982, Pusey 1987, Wolff 1993). However, there is considerable controversy about the relative roles of these two processes in structuring dispersal patterns within and among species (Bengtsson 1978, Moore and Ali 1984, Dobson and

${ }^{1}$ University of British Columbia; ${ }^{2}$ Simon Fraser University 
Jones 1985, Shields 1987, Wolff 1993, Kunkele and von Holst 1996). All hypotheses assume that dispersers incur costs to survival and/or fecundity (Bengtsson 1978) and that these costs increase with distance traveled. Dispersing individuals may face increased mortality risks associated with unfamiliar habitats, passage through areas of relatively high predator densities, or the physiological costs of extensive movement (Waser et al. 1994, Plissner and Gowaty 1996).

Lack of quantitative methods for predicting the spatial scale of dispersal from natal habitats is a major limitation in the development of theories and tools for forecasting the effects of landscape alteration on connectivity between habitats and subpopulations of animals. Recent spatially explicit models for assessing the effects of habitat fragmentation on populations of animals require knowledge of the dispersal characteristics of their target species. For example, two key parameters are the dispersal rate (number of dispersers leaving their natal territory) and the expected distance dispersed by each disperser (Pulliam et al. 1992, With and Crist 1995, Schumaker 1996). However, dispersal characteristics of this type are known in detail for only a few species. While simple mathematical models have been fit to the dispersal distributions of some of these species (Waser 1987, Miller and Carroll 1989, Caley 1991), generalizing them to other species is questionable. Parameter estimates vary widely among species (Miller and Carroll 1989), and many models assume particular behavioral mechanisms governing the distance moved by individual dispersers that may themselves not be general (Rees 1993). Interstudy differences in the intensity of sampling and the high probability of biases introduced through restricted searching patterns (Porter and Dooley 1993) further reduce the generality of these models.

The prominent role of dispersal in the life history of most species suggests that relationships exist between dispersal patterns and basic life-history attributes of species. Indeed, some have recently been described: mean and standard deviation (SD) of natal and breeding dispersal distances in many species of British birds depend on habitat type and migratory capability, with body size as a covariate (Paradis et al. 1998). However, for some species of mammals, median dispersal distance appears to be related to diet type and body size (Van Vuren 1998). We wished to place the analysis of these relationships into a common ecological framework and determine general, predictive relationships for birds and mammals. Accordingly, we developed a number of a priori expectations regarding how attributes of species should relate to their ability to disperse a given distance:

1. Dispersal distance should increase with increasing body size. Scaling functions that relate body size to interspecific variation in biological functions ranging from rates of cellular metabolism to population dynamics are common (Peters 1983, Schmidt-Nielsen 1984, Holling 1992, Silva 1998). Generally, such functions can be explained in terms of how individuals acquire and use resources as a function of body size (Brown and Maurer 1989, Kozlowski and Weiner 1997, West et al. 1997). In particular, allometric scaling equations with an exponent value of approximately $3 / 4$ are expected for sizedependent resource utilization relationships (McNab 1963, Peters 1983, West et al. 1997). The dominant hypotheses about the ultimate benefits of dispersal can also be interpreted broadly in terms of the availability of resources (ecological or genetic). Larger animals also have more time, on average, to explore (both between meals and over a lifetime) as longevity increases with body mass ( Peters 1983). Both explanations lead to the prediction that larger species will disperse farther (assuming some benefit to dispersing); thus, across species we expected body mass to be significantly correlated with dispersal distance.

2. Dispersal distance should increase with increasingly exclusive acquisition of resources. We examined two correlates of spacing behavior: diet type and social system. Diets vary in resource abundance and predictability, and diet type influences spacing behavior (Harestad and Bunnell 1979). Because utilizable energy per unit area is greater at lower trophic levels (Harestad and Bunnell 1979) and because home range size increases with decreasing resource abundance (Mace et al. 1982), we predicted that predators would disperse farther than omnivores and that omnivores would disperse farther than herbivores. In both birds and mammals, factors such as type of mating system and form of territorial defense can influence the relative distance moved by dispersers (Greenwood 1980). For example, if males defend resources, females usually disperse farther (Greenwood 
and Harvey 1982). If both sexes defend territories, gender bias in dispersal does not occur in some species (Mattysen and Schmidt 1987, Arcese 1989). Males are likely to disperse farther in polyandrous species (Oring and Lank 1984) and if males defend females (Lessels 1985). We predicted that species defending breeding territories should disperse farther than species with overlapping or nonexclusive territories. Patterns of dispersal distances in more gregarious species (e.g., colonial nesters) could potentially differ substantially from those of nongregarious species, depending on the density, geographic range, and aggregation patterns of breeding sites within and among colonies. For example, median distances may be quite short if colonies are clumped in distribution, but maximum distances may be very long if colonies are sparsely dispersed at a large (e.g., continental) geographic scale.

3. In birds, dispersal distances for migrants should exceed those for residents. Recent evidence suggests that the breeding dispersal distances for migrant species are longer than those for resident species (Paradis et al. 1998), although this result was not found for natal dispersal distances.

4. Dispersal distances for closely related species should be more similar than for less closely related species. Interspecific comparisons of ecological relationships are often confounded because species are part of a hierarchically structured phylogeny and cannot be regarded, for statistical purposes, as if drawn independently from the same distribution (Felsenstein 1985). In our study, evolutionary factors determining body size, although likely independent of dispersal, may be strongly correlated in closely related species.

If the dispersal distance varies predictably with these life-history attributes, then researchers could use such relationships to identify species potentially vulnerable to loss of connectivity between habitats, and habitat planners could use these relationships to assess the potential risks of alternative habitat configurations to locally vulnerable species.

In this paper, we define dispersal as the movement of an individual out of an area larger than its home range, with no predictable returns, i.e., excluding migrations
(Bunnell and Harestad 1983). For most species and most dispersing individuals, dispersal takes place before first reproduction and is termed natal dispersal (Howard 1960). Natal dispersal is usually the single largest (and often only) long-distance movement made by individual animals (Dice and Howard 1951) and is generally accepted as the major agent of gene flow among populations (Wiklund 1996). Dispersal by reproductive adults, if it occurs, has consequences for the lifetime reproductive success of individuals (Clutton-Brock 1988, Newton 1989). Because of its importance for interpopulation genetic structure and local population dynamics, we focused our analyses on patterns of natal dispersal, rather than breeding dispersal.

We do not address in detail the variety of reasons, proximate and ultimate, why an animal might disperse from its natal area, the factors that directly determine mortality during dispersal, or year-to-year variation in dispersal success. However, given that animals do disperse and that the chances of dispersers successfully colonizing a site remain approximately constant from year to year, we do consider the nature of relationships among distance dispersed, body mass, and other lifehistory attributes of species.

\section{METHODS}

\section{Data collection}

We searched papers published between 1930 and mid1998 for reports of natal dispersal movements by birds and mammals, excluding marine species and bats. Our geographically unrestricted survey did not include papers written in languages other than English or unpublished theses (except in cases where raw data for a species were made available to us). Most documented long-distance movements are based either on incidental observations of dispersals made by individual animals or on much more detailed investigations that yield frequency distributions of dispersal distances for one or more populations. More observations of a single long distance moved by a dispersing animal were reported in studies of mammals than in studies of birds.

Wide variation in study designs, objectives, and methods of quantifying dispersal required that we develop screening criteria for selecting dispersal data suitable for comparative analyses. Therefore, we accepted dispersal data only if authors: 
1. reported individual dispersal distances (or ranges) rather than means or medians only;

2. reported net (minimum straight-line distance) rather than gross distance moved;

3. did not include observations of likely migrants as dispersers. We accepted subsets of data if authors provided some evidence of the nonmigratory status of some individuals. Distinguishing dispersal from migration is important for several reasons. In birds, postfledging exploratory movements may have a function in locating future breeding sites, locating sites suitable for overwintering, or establishing a navigational target, all of which could confound interpretation of dispersal movements (Baker 1993);

4. gave single observations of long-distance dispersal, provided the authors had evidence that the disperser was marked at or near its natal site and that the reported movement met our criteria for natal dispersal movements (as defined above); or

5. either observed breeding (or, for banding studies, specified breeding season returns) or, for species with delayed maturity, provided evidence of little movement after settlement.

Many studies reporting data on natal dispersal do not control biases in measurement, such as the decreased likelihood of detecting a dispersing animal at the edge of a study area. Therefore, we further screened studies presenting distance-density distributions of dispersal, selecting only those that did not truncate distances by using a small study area. We did include studies involving several small study areas with a potential for observing movement between sites. We accepted statements of the adequacy of site size when surveys of surrounding areas did not extend the distribution of distances. Some authors also included correction factors for potential biases in their data; we used these if provided.

For each study selected, we recorded all given dispersal data. If raw distance-density data were provided in tables, we recorded them, maintaining data separately for each sex if possible. Numerical values were also estimated from figures. Small figures with $\log$ scales probably resulted in some measurement error for long distances. We converted distances given as numbers of territories or home ranges crossed to kilometers, assuming packed circular territories of the mean size measured in the study. Where available, we also recorded median, mean, and maximum dispersal distances. For each study, we recorded how observations were obtained (e.g., radiotelemetry, tagging, hunter returns, etc.). Within studies, telemetry data were chosen over single observations when both were given. We ignored data on nondispersal movements.

We determined mean adult body mass for each species and sex from the original studies (if given) or from standard references: Dunning (1993) for birds and Silva and Downing (1995a) for mammals. We also identified the following categorical variables as potential ecological and life-history correlates of dispersal distance:

1. Diet type. We classified all bird and mammal species into three diet groups based on the main foods consumed throughout the year: herbivores (including seed eaters), carnivores (including insectivores), and omnivores. Definitions follow Schoener (1968): herbivores ingest $<10 \%$ by volume animal matter, whereas carnivores ingest $>90 \%$ by volume animal matter on an annual basis. All species ingesting $10-90 \%$ animal matter are omnivores. We used supplemental dietary information from Ehrlich et al. (1988) for birds or from our source studies.

2. Social system during the breeding season. We classified this as territorial, nonexclusive (broad overlap between home ranges), or gregarious (including herding and colonial species).

3. Migratory status (birds only). We classified bird species as migrants (including partial migrants) or residents. All of our dispersal data for mammals came from nonmigratory periods, so we did not include this variable for mammals.

4. Phylogeny. To assess the influence of relatedness on dispersal scale, we included taxonomic family as a categorical variable in our analyses.

The data and references used in our analyses are summarized in Tables A1 and A2 in Appendix 1.

\section{Data analysis}

Our general approach was to use robust methods for estimation wherever possible and to develop simple, 
empirical relationships for prediction, rather than constructing process-based models. Dispersal is a complex phenomenon that makes it difficult to develop general models based on interspecific comparisons (Paradis et al. 1998). Besides the previously mentioned potential for sampling biases, sample sizes differ between studies, fates of dispersers are not always known, and dispersers of different species may be responding to different proximate factors. We therefore treated our data as follows.

To examine underlying similarities in dispersal patterns between sexes and among species, we needed to rescale the frequency distributions of dispersal distances obtained from each study to a common unit of measurement. We rescaled each distribution to a ratio of the distance moved by $50 \%$ of the observed dispersers (hereafter referred to as the median distance). If the distribution was given in intervals, we used the midpoint of the interval containing the median. Subsequent analyses involving frequency distributions used these rescaled values.

To evaluate the relationships between dispersal distances and life-history characteristics, we used the following methods based on median and maximum distances moved by dispersers of each species. First, we logarithmically transformed all body masses and dispersal data (median and maximum distances) to stabilize variances, linearize responses, and normalize residuals. We then examined normal quantile-quantile plots of all transformed data to test for departures from normality, finding that most dispersal distance data remained significantly non-normal after $\log _{10}$ transformation.

Second, we used ordinary least squares (Type I) regression to develop all predictive allometric relationships, because we did not have error distributions of body mass data for most species of the type proposed by LaBarbera (1989) in his discussion of appropriate regression methods in allometric analyses. Before finalizing the regressions, we examined the influence of each observation on the estimated regression coefficients using Cook's (1977) distance and eliminated observations with a Cook's distance $>1.0$. All estimated coefficients derived from allometric equations based on $\log _{10}$ were corrected for bias using the methods of Sprugel (1983). Because of departures from normality, we estimated standard errors and confidence limits of the allometric equation coefficients using 1000 replicate bootstrap samples of the data. We adjusted for bias following Efron and Tibshirani (1993). All analyses were done with S-Plus (MathSoft 1998).

Table 1. Summary shape statistics (means \pm SD) for the original frequency distributions of detected natal dispersal distances analyzed in this study. Distributions presented here were not transformed or rescaled prior to analysis. The skewness and kurtosis of each distribution were calculated using Pearson moment statistics. Tests of the deviation of the population of shape parameters from a normal distribution were done using $t_{0.05}$ (Sokal and Rolf 1995).

\begin{tabular}{|c|c|c|c|c|c|c|}
\hline & \multirow{2}{*}{$n$} & \multirow{2}{*}{$\begin{array}{l}\text { Percent with } \\
1 \text { mode }\end{array}$} & \multicolumn{2}{|c|}{ Skewness } & \multicolumn{2}{|c|}{ Kurtosis } \\
\hline & & & $\lambda_{3}$ & $P$ & $\lambda_{4}$ & $P$ \\
\hline \multicolumn{7}{|l|}{ Birds } \\
\hline Females & 24 & 50.0 & $1.06( \pm 1.37)$ & $<0.001$ & $2.21( \pm 4.88)$ & $<0.050$ \\
\hline Males & 23 & 58.8 & $1.40( \pm 0.63)$ & $<0.001$ & $1.85( \pm 2.49)$ & $<0.002$ \\
\hline Sexes not separated & 21 & 40.0 & $1.50( \pm 1.05)$ & $<0.001$ & $2.44( \pm 5.71)$ & $<0.20$ \\
\hline \multicolumn{7}{|l|}{ Mammals } \\
\hline Females & 22 & 62.5 & $1.51( \pm 1.08)$ & $<0.001$ & $2.91( \pm 4.09)$ & $>0.400$ \\
\hline Males & 20 & 63.6 & $1.22( \pm 1.09)$ & $<0.001$ & $2.09( \pm 3.09)$ & $<0.001$ \\
\hline Sexes not separated & 5 & 50.0 & $0.75( \pm 0.84)$ & $>0.15$ & $-0.21( \pm 2.54)$ & $>0.50$ \\
\hline
\end{tabular}




\section{RESULTS}

Usable dispersal data were found for 77 bird and 68 mammal species (see Tables A1 and A2 in Appendix 1). Dispersal data were reported separately by sex in the majority of cases: $52 \%$ for birds and $76 \%$ for mammals. Within each class, the range of natal dispersal movements varied by at least two orders of magnitude for both median distances. In the case of birds, median distances ranged from $0.03 \mathrm{~km}$ for the House Martin (Delichon urbica) to $10 \mathrm{~km}$ for the Glaucous-winged Gull (Larus glaucescens). For mammals, median distances ranged from $0.03 \mathrm{~km}$ for the common vole (Microtus agrestis) to $129.7 \mathrm{~km}$ for the gray wolf (Canis lupus). Maximum distances for birds ranged from $1.3 \mathrm{~km}$ for the European Magpie (Pica pica) to $1305 \mathrm{~km}$ for the Great Horned Owl (Bubo virginianus), and, for mammals, from $0.14 \mathrm{~km}$ for the prairie vole (Microtus ochrogaster) to 930.1 $\mathrm{km}$ for the lynx (Lynx lynx).

\section{Distributions of dispersal distances}

The distributions of the 107 dispersal distance data sets exhibited left skewness and platykurtosis (Table 1 ), indicating that many dispersers cluster near the natal areas, whereas others disperse relatively far from their natal areas (Turchin 1998). This pattern was significant for all class and sex comparisons, except for mammals in studies where the sexes were not separated. Shape statistics based on the original distance-density distributions are highly variable, particularly for distances dispersed by females (Table 1). This variability, coupled with different methods of categorizing distances among studies, suggested that further analysis of sources of variation in the patterns of dispersal in birds and mammals was warranted.

Once distances were rescaled to units of the median dispersal distance for each distribution, comparative analyses revealed that the distributions were statistically indistinguishable between sexes and between noncarnivores (herbivores and omnivores combined) and carnivores. In two sample Kolmogorov-Smirnov tests, the sex-based values were $D=0.042, P_{\alpha=0.05,100}>0.5$ for birds and $D=0.023$, $P_{\alpha=0.05,100}>0.5$ for mammals. The noncarnivore vs. carnivore values were $D=0.015, P_{\alpha=0.05,100}>0.5$ for birds and $D=0.029, P_{\alpha=0.05,100}>0.5$ for mammals. Consequently, for both classes we pooled distributions for different sexes and diet types.
Fig. 1. Empirical distributions of distances moved by juveniles dispersing from their natal areas. Each data point represents the number of juveniles dispersing that particular distance according to the original study. All dispersal distances shown are scaled to the median dispersal distance $(D)$ for the population estimated from the data presented in each original study. Sexes are pooled for each class. Also shown for each class is the LOESS smoothed line through the data (Cleveland et al. 1992) using a quadratic smoothing algorithm.

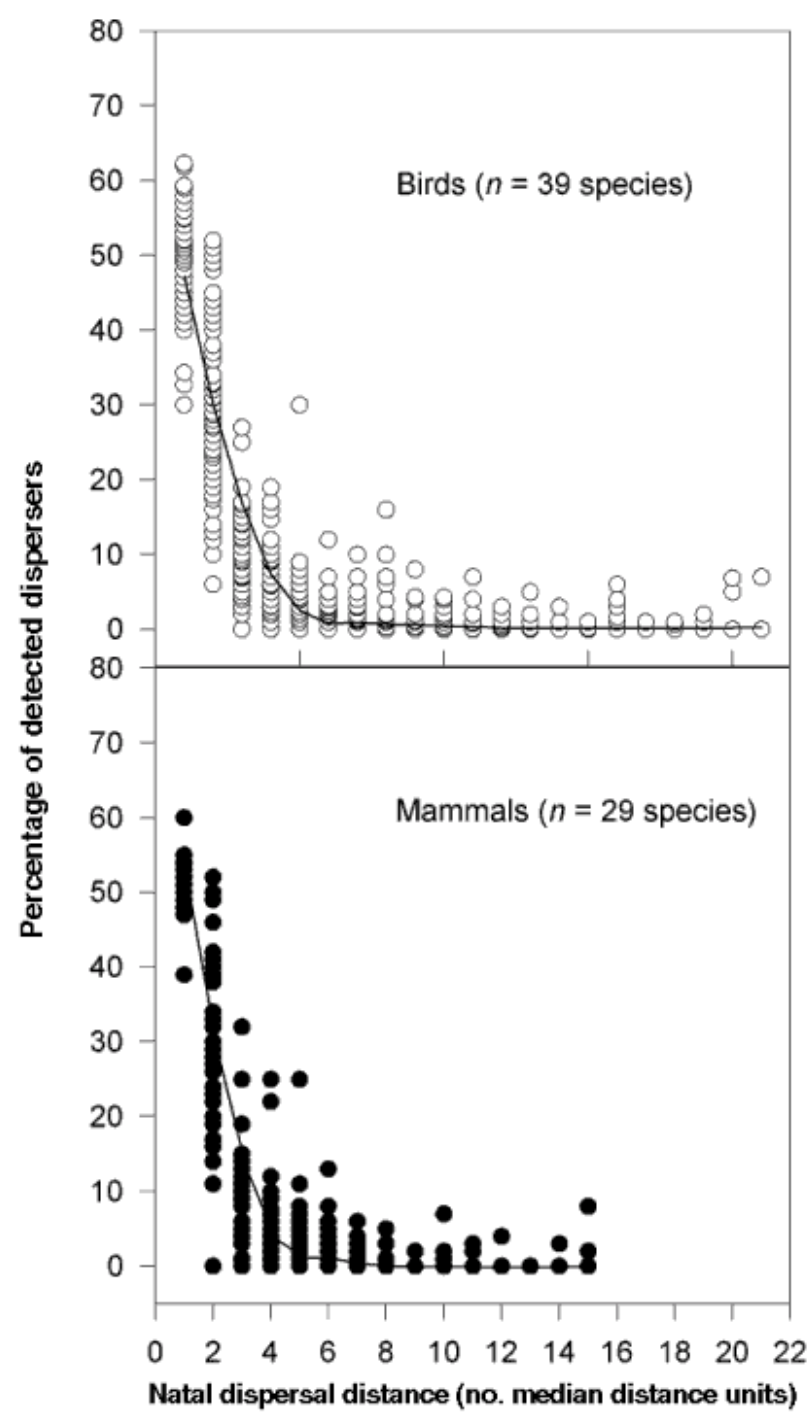

Two broad patterns were evident in these pooled data. First, rescaled dispersal distance distributions for bird and mammal species were very similar in shape (Fig. 1). Second, for both classes, the rescaled dispersal distributions showed a strong decline in frequency with increasing distance from the natal area (Fig. 1). In both birds and mammals, most detected dispersal 
distances were less than 3 median distances from the natal area; only 9 of 35 bird species and 2 of 19 mammal species showed juveniles dispersing farther than 10 median distances. At least part of the decline in the numbers of birds and mammals was probably due to the reduced likelihood of detecting animals far from the natal area. Although we attempted to screen out data where this problem was clearly evident, subtle sampling biases of this type were more difficult to identify. We therefore treated the rescaled distributions as estimates of minimum dispersal distances only, and not as estimates of "true" but unknown dispersal distances.

Rare long-distance dispersals often appear at the extreme right of frequency distributions of dispersal, although their effects on determining the dispersal scale of species are usually difficult to take into account (Turchin 1998). To test for the presence of "fat tails" in the rescaled distributions, we used polynomial regression to examine the significance of the coefficients $\left(b_{0}, b_{1}, b_{2}\right)$ in the relationship $\ln$ (dispersers) $)_{x}=b_{0}+b_{1} x+b_{2} x^{2}$, where $x$ is distance dispersed. We found that, in both birds and mammals, the $b_{2}$ coefficients were significantly greater than 0 : for birds, this value was $t_{0.05,19}=8.93, P<0.0001$; for mammals, $t_{0.05,12}=7.67, P<0.0001$. This confirmed that the tails were fatter than expected under an assumption of a Gaussian distribution (Turchin 1998). Although more detailed statistical analysis of the tails is not warranted here because of potential biases in the original data, this result is consistent with a dispersal pattern created by highly variable dispersal distances that also includes rare long-distance dispersal events.

\section{Allometric scaling of dispersal distances}

The frequency of natal dispersal (i.e., the proportion of individuals dispersing) is female-biased in birds and male-biased in mammals (Greenwood 1980), leading to the expectation that female birds and male mammals may also disperse farther than their counterparts of the opposite sex. We could not find strong enough evidence for these hypotheses in our data to warrant separate analyses for males and females. There are high probabilities that median and maximum dispersal distances show no significant sex bias. Sign tests comparing distances dispersed by females and males of the same species showed that, for birds, median distances were $P=0.402, n=16$ and maximum distances were $P=0.254, n=9$, whereas, for mammals, median distances were $P=0.613, n=$ 12 and maximum distances were $P=0.06, n=8$.
However, it is possible that the lack of significance in our findings for the maximum distance comparison in birds and mammals was due to small sample sizes. Except where indicated below, we pooled the sexes together for the remainder of our interspecific comparisons.

Do dispersal distances scale with body mass and other ecological factors that may determine the density and dispersion of breeding sites across the landscape? Based on our initial expectations, we tested the importance of average adult body mass $M$ in explaining variations in median dispersal distances $\left(D_{\text {median }}\right)$ and maximum dispersal distances $\left(D_{\max }\right)$ in birds and mammals. Both $D_{\text {median }}$ and $D_{\max }$ increased significantly with increasing body mass in both classes, and the variation in dispersal distance explained by body mass was higher for maximum dispersal distance in mammals (Table 2). By comparing bootstrapped confidence intervals for each measure (median vs. maximum distance), we found that the estimated slopes of these relationships did not differ at $\alpha=0.05$ between either measure within classes or each measure between classes. Nevertheless, the intercepts between measures differed significantly for each class. The estimated maximum distance that dispersing individuals of a species with a given body mass were expected to move was 4.9 and 5.8 times the median dispersal distance in birds and mammals, respectively (based on ratios of intercepts). Over the range of comparable body masses, ratios of predicted dispersal distances for birds and mammals combined vary between 5.1 and 9.5 (median distance) and 5.0 and 56.0 (maximum distance). Overall, birds dispersed between 0.5 and 1.5 orders of magnitude farther than mammals of equivalent body mass. Although body mass was a significant predictor of both median and maximum dispersal distances for mammals, it was clearly weak in predicting maximum dispersal distance for birds.

When we separated species within classes by diet type, estimated allometric relationships were consistently stronger for carnivorous species than for herbivores or omnivores (Figs. 2 and 3). For herbivorous and omnivorous birds, the percentage of unexplained variance in median or maximum dispersal distance ranged between $86 \%$ and $98 \%$ after accounting for body mass. The slopes of the allometric regressions were not significantly different from 0 for either diet type or dispersal measure in herbivorous and omnivorous birds $(P>0.154$ for all slopes), whereas the slopes were significantly different from 0 for 
carnivorous birds $(P \leq 0.0005$ for both median and maximum distances). Furthermore, slopes for carnivorous birds did not differ significantly from 0.75 (bootstrapped 95\% confidence range for median, 0.49-
1.21; maximum, 0.32-0.77), although there was considerable residual uncertainty about the slope (Fig. 2).

Table 2. Summary of equations converting body mass $M$ (in $\mathrm{kg}$ ) to type of dispersal distance (in $\mathrm{km}$ ) in birds and mammals. Shown are separate Type I regression coefficients $( \pm \mathrm{SD})$ and regression statistics for species of each diet type $(" \mathrm{C} "=$ carnivores, "H+O" = herbivores and omnivores pooled, and "Combined" = all diet types combined).

\begin{tabular}{|c|c|c|c|c|c|c|}
\hline Class & Dispersal distance type & Trophic type & Equation & df & $\mathbf{r}^{2}$ (adjusted) & $P$ \\
\hline \multirow[t]{6}{*}{ Birds } & \multirow[t]{3}{*}{ Median } & $\mathrm{C}$ & $36.4( \pm 1.33) M^{0.62( \pm 0.27)}$ & 12 & 0.24 & 0.0440 \\
\hline & & $\mathrm{H}+\mathrm{O}$ & $\begin{array}{l}2.1( \pm 1.76) \\
M^{0.18( \pm 0.18)}\end{array}$ & 24 & 0.04 & 0.3300 \\
\hline & & Combined & $\begin{array}{c}13.1( \pm 1.47) \\
M^{0.63( \pm 0.15)}\end{array}$ & 36 & 0.32 & 0.0001 \\
\hline & \multirow[t]{3}{*}{ Maximum } & $\mathrm{C}$ & $199.5( \pm 1.38) M^{0.59( \pm 0.13)}$ & 34 & 0.33 & 0.0003 \\
\hline & & $\mathrm{H}+\mathrm{O}$ & $36.4( \pm 1.55) M^{0.14( \pm 0.15)}$ & 41 & 0.02 & 0.6600 \\
\hline & & Combined & $73.3( \pm 1.31) M^{0.34( \pm 0.10)}$ & 75 & 0.09 & 0.0030 \\
\hline \multirow[t]{6}{*}{ Mammals } & \multirow[t]{3}{*}{ Median } & $\mathrm{C}$ & $3.45( \pm 1.07) M^{0.89( \pm 0.03)}$ & 10 & 0.88 & $\begin{array}{c}< \\
0.0001\end{array}$ \\
\hline & & $\mathrm{H}+\mathrm{O}$ & $1.45( \pm 1.05) M^{0.54( \pm 0.01)}$ & 18 & 0.74 & $\begin{array}{c}< \\
0.0001\end{array}$ \\
\hline & & Combined & $2.04( \pm 1.32) M^{0.67( \pm 0.09)}$ & 28 & 0.42 & 0.0010 \\
\hline & \multirow[t]{3}{*}{ Maximum } & $\mathrm{C}$ & $40.7( \pm 1.41) M^{0.81( \pm 0.14)}$ & 48 & 0.73 & $\begin{array}{c}< \\
0.0001\end{array}$ \\
\hline & & $\mathrm{H}+\mathrm{O}$ & $3.31( \pm 1.17) M^{0.65( \pm 0.05)}$ & 15 & 0.75 & 0.0001 \\
\hline & & Combined & $6.46( \pm 1.23) M^{0.68( \pm 0.08)}$ & 63 & 0.72 & $\stackrel{<}{<}$ \\
\hline
\end{tabular}

For mammals, the unexplained variance in median and maximum dispersal distances after accounting for allometric relationships was less than $32 \%$ for all regressions. Analysis of covariance indicated that the intercepts of the relationships for carnivorous mammals differed significantly from those of herbivores and omnivores $(P<0.03)$, although the slopes of the regressions did not differ. We therefore pooled our data for herbivores and omnivores (Fig. 3).
Dispersal distances of mammalian carnivores were considerably longer than those of herbivores and omnivores. The predicted ratios of carnivore dispersal distances to herbivore/omnivore distances ranged between 1.2 and 4.5 (median distance) and 7.1 and 18.3 (maximum distance) for mammals of equivalent body mass. As in birds, the slopes of the regressions for carnivorous mammals did not differ significantly from 0.75 (bootstrapped 95\% confidence range for 
median, 0.65-1.11; maximum, 0.64-1.10), although the slopes for both measures calculated for the combined herbivore and omnivore data were both <
0.75 (bootstrapped 95\% confidence range for median, 0.39-0.70; maximum, 0.56-0.72).

Fig. 2. Allometric relationships in birds between body mass $(M)$, median dispersal distance $\left(D_{\text {median }}\right)$ on the left, and maximum dispersal distance $\left(D_{\max }\right)$ on the right. Solid triangles represent data points for herbivores, open circles represent data points for omnivores, and solid circles represent data points for carnivores. Significant Type I regressions (-) are shown for carnivores only (see Table 2 for equations), along with their 95\% confidence bands (...) and 95\% prediction bands (----). Sexes or other categorical variables are not differentiated in this figure.

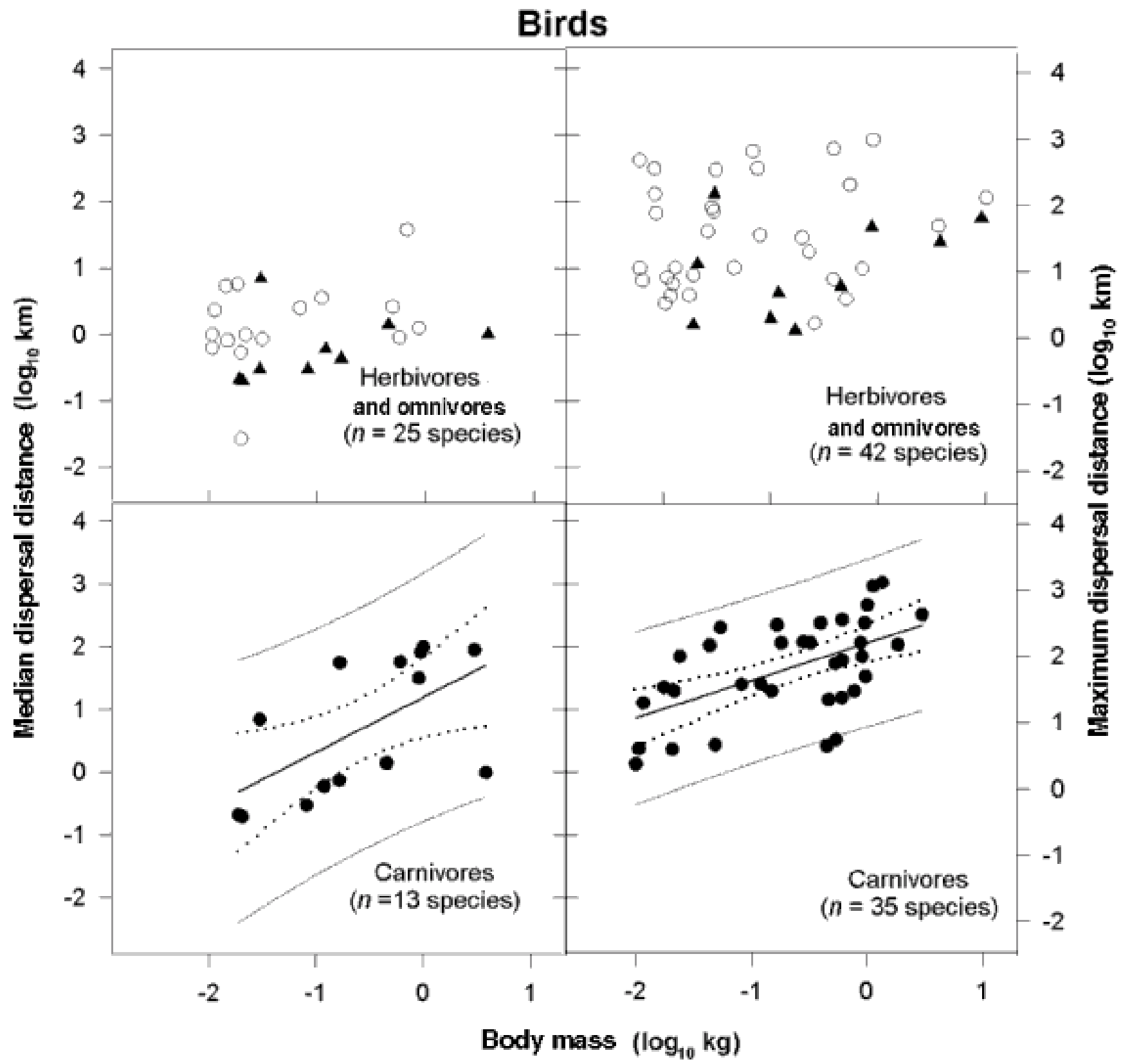


Fig. 3. Allometric relationships in mammals between body mass, median dispersal distance on the left, and maximum dispersal distance on the right. Symbols are as in Fig. 2. Significant Type I regressions are given for herbivores and omnivores (pooled) and for carnivores (see Table 2 for equations). Sexes and other categorical variables are not differentiated. Note the difference in $x$-axis scale between this figure and Fig. 2.

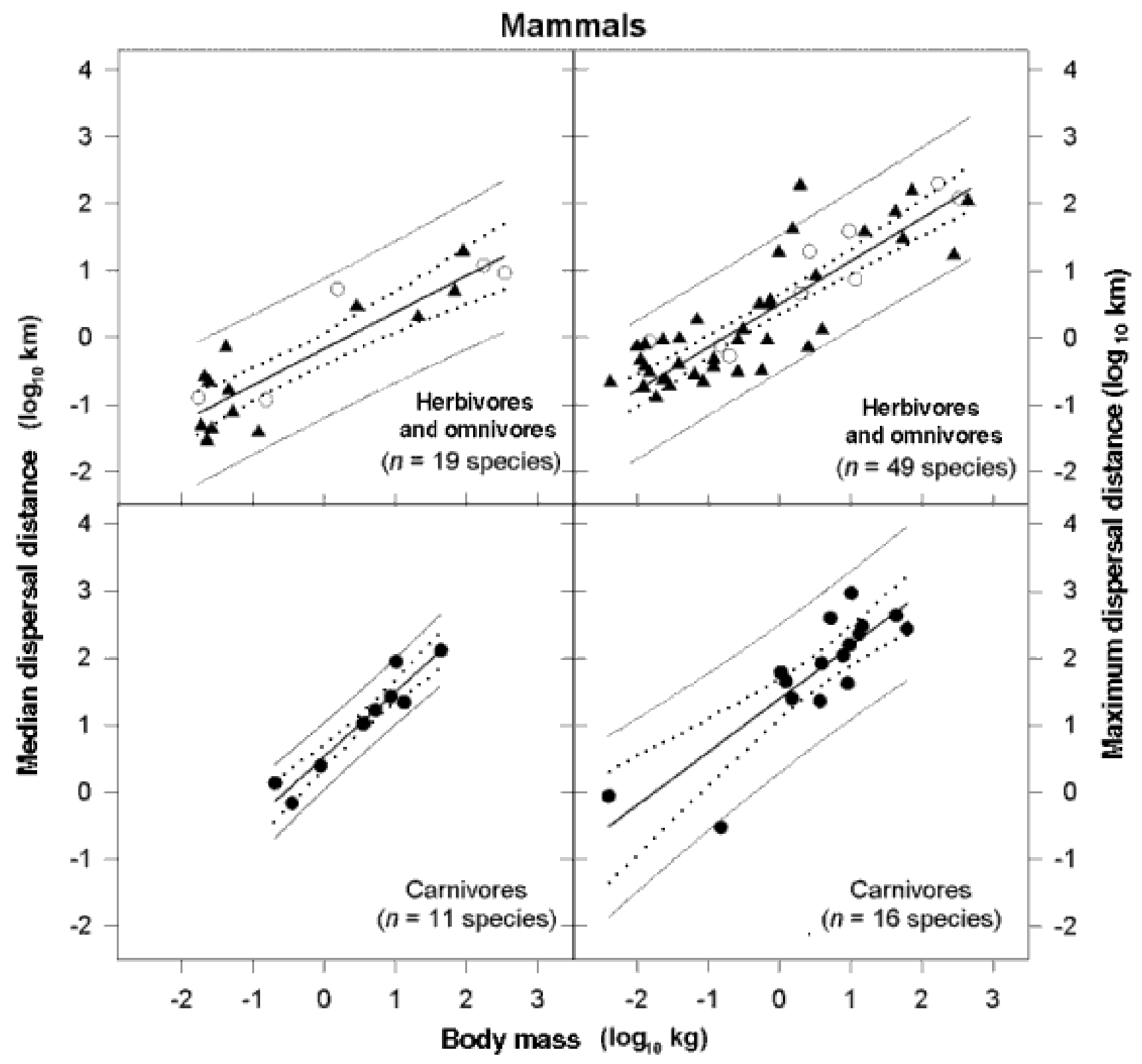

We examined the relationships between our two measures of dispersal distance (median and maximum) and the categorical life-history variables after we removed the influences of body mass and diet type (Table 3). Except for family and migratory type in birds, we found little evidence for the effects of these variables on either median or maximum dispersal distances in birds or mammals (Table 3). We found that observed maximum distances dispersed by species of Corvidae, particularly Gray Jay (Perisoreus canadensis) and Magpie (Pica pica), and Fringillidae, namely Song Sparrow (Melospiza melodia), Savannah Sparrow (Passerculus sandwichensis), and Whitecrowned Sparrow (Zonotrichia leucophrys), were 
shorter, averaging $72 \%$ less than the predicted value. In contrast, those of the Laridae, including the lesser Black-backed Gull (Larus fuscus), the Glaucouswinged Gull (L. glaucescens), the Ring-billed Gull ( $L$. delawarensis), and the Herring Gull (L. argentatus), and the Motacillidae, particularly the White Wagtail (Motacilla alba) and the Yellow Wagtail (M. flava)), were longer than expected, averaging $60.7 \%$ farther than the predicted value based on the general body mass-diet type relationship for birds. In addition, the maximum distances dispersed by migratory bird species were significantly farther than for resident species (Table 3); class averages for migratory species were $28.4 \mathrm{~km}, n=39$, and, for resident species, 24.3 $\mathrm{km}, n=34$. Our data provided no clear evidence that social system was a correlate of the distance of dispersal in either birds or mammals, although, in general, low power precluded eliminating this variable from further study (Table 3).

Table 3. Effects of categorical variables on median and maximum dispersal distances of birds and mammals after removing the effects of body mass and diet type. Shown are all main effects and significant interactions. Effects significant at $\alpha=0.05$ are marked with an asterisk (*). Comparisons with too few observations for analysis are indicated by an ellipsis ("...").

\begin{tabular}{|c|c|c|c|c|c|c|c|c|c|}
\hline \multirow{2}{*}{ Class } & \multirow{2}{*}{ Variable } & \multicolumn{4}{|c|}{ Median dispersal } & \multicolumn{4}{|c|}{ Maximum dispersal } \\
\hline & & $F$ & d.f. & $P$ & Power & $F$ & d.f. & $P$ & Power \\
\hline \multirow[t]{4}{*}{ Birds } & Family & 2.21 & 9,27 & $0.05^{*}$ & 0.88 & 0.64 & 11,77 & 0.77 & 0.35 \\
\hline & Migration & 0.01 & 1,27 & 0.93 & 0.10 & 0.68 & 1,77 & 0.41 & 0.15 \\
\hline & $\begin{array}{l}\text { Social } \\
\text { system }\end{array}$ & 0.08 & 2,27 & 0.27 & 0.12 & 0.10 & 2,77 & 0.91 & 0.11 \\
\hline & $\begin{array}{l}\text { Migration x } \\
\text { social } \\
\text { system }\end{array}$ & $\ldots$ & $\cdots$ & $\cdots$ & $\cdots$ & 191.20 & 22,77 & $0.046^{*}$ & 0.97 \\
\hline \multirow[t]{3}{*}{ Mammals } & Family & 0.22 & 10,17 & 0.99 & 0.98 & 1.76 & 15,48 & 0.20 & 0.64 \\
\hline & $\begin{array}{l}\text { Social } \\
\text { system }\end{array}$ & 2.14 & 1,17 & 0.16 & 0.45 & 0.11 & 2,48 & 0.89 & 0.12 \\
\hline & $\begin{array}{l}\text { Family } x \\
\text { social system }\end{array}$ & 0.02 & 1,17 & 0.89 & 0.10 & 0.80 & 30,48 & 0.73 & 0.41 \\
\hline
\end{tabular}

By studying patterns of residuals after the influences of body size and diet type had been removed, we tested for two possible trends in our data. First, we searched for systematic biases introduced by the method of obtaining dispersal data. We found no evidence that the observation method biased the results in either birds or mammals. One-way ANOVA yielded a median distance of $F_{0.05,3,347}=1.17, P=0.33$ and a maximum distance of $F_{0.05,3,74}=1.42, P=0.51$ for birds, and a median distance of $F_{0.05,2,10}=1.72, P=$ 0.20 and a maximum distance of $F_{0.05,2,64}=0.72, P=$
0.49 for mammals.

Second, because birds are more mobile than mammals, we considered the possibility that their observed dispersal distances might also be more variable than those of mammals. When we looked at how the observed dispersal distance values were dispersed with regard to their predicted values between classes and diet types, we found no evidence that this was the case. In fact, it is possible that dispersal distances for mammals may be relatively more variable than those 
for birds: paired $t$ tests of coefficients of variation yielded values of $t_{0.05(2), 3}=1.95, P=0.15$.

Fig. 4. Relationship between the median dispersal distance $\left(D_{\text {median }}\right)$ and the maximum dispersal distance $\left(D_{\max }\right)$ observed in birds and mammals. Birds are represented by open circles and mammals by solid circles. Also shown is the fitted Type I regression line (-) for the pooled data, the $95 \%$ confidence band $(\cdots$.$) , and the 95 \%$ prediction band (----) for the relationship. The sexes are not differentiated.

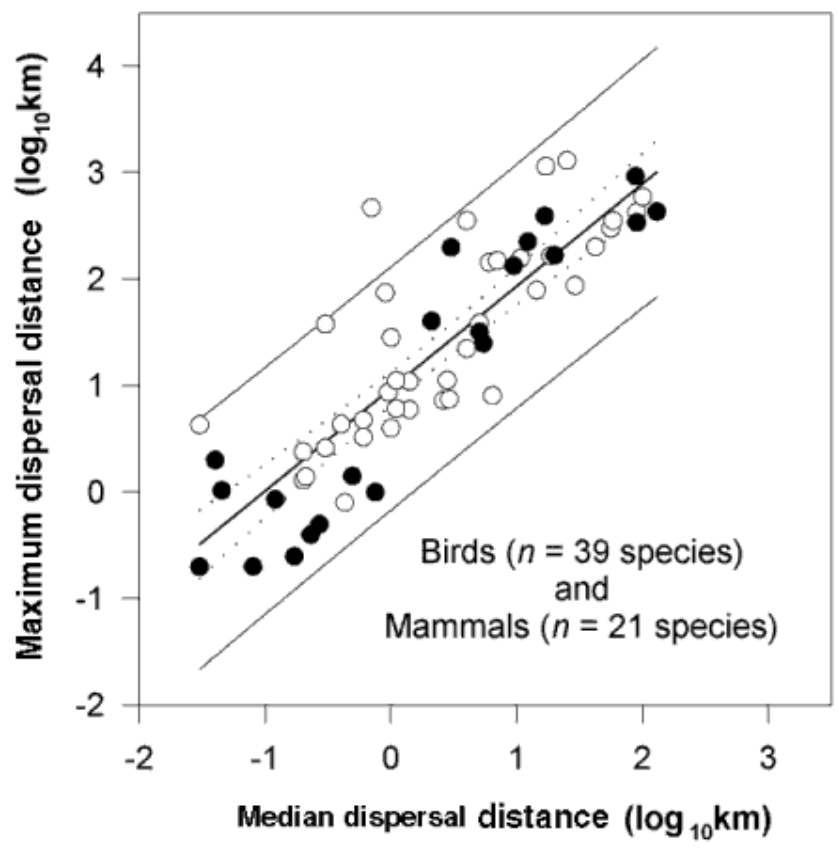

Because we could estimate the median and maximum dispersal distances for a given species from the body mass and diet type relationships in Figs. 2 and 3 and Table 2, we wondered if we could also estimate the median distance dispersed from the maximum distance, and vice versa. To examine this, we chose only those species of birds and mammals for which we had both a maximum dispersal distance observation and a median dispersal distance. As expected, both classes showed a significant relationship between maximum and median distances, and, as seen in Fig. 4, $D_{\max }=9.77( \pm 1.23 \mathrm{SD}) \times D_{\text {median }}=0.98( \pm 0.08 \mathrm{SD})$, $\mathrm{df}=59$, adjusted $r^{2}=0.73, P=0.0001$. For both birds and mammals, the slope of the line was not significantly different from a 1:1 relationship, although birds had a higher intercept than mammals.

\section{An empirical probability model for the minimum distance of dispersal}

To infer the minimum probability that a dispersing animal could disperse a given distance using data on its body mass, diet type, and the relationships in Table 2 and Figs. 2, 3, and 4, we derived a simple phenomenological model based on the empirical density-distance curves in Fig. 1. Our intention was to develop general relationships for estimating the minimum probability that a given animal would disperse beyond a particular distance. For the range of species that we examined, potentially there were many varied mechanisms that could govern the decision of a dispersing individual to settle at a site. We chose a conservative dispersal model based on negative exponential distribution as the simplest and most general description of the data. This distribution assumed that, over a large area and a sufficiently long time, the probability of predicting the dispersal distances of individuals could be approximated by a Poisson process. Other process-based models derived from alternative hypotheses to determine where dispersers settle have also been developed (Taylor 1980, Miller and Carroll 1989, Caley 1991, Turchin 1998). In many cases, these models do not describe dispersal patterns any better than does the negative exponential, even for single species (Miller and Carroll 1989, Caley 1991). If $X$ is the potential distance dispersed by an individual originating in a natal area, with an expected distance of $\theta$, then the distribution function of $X$

$$
F(x)=\left\{\begin{array}{l}
0,-\infty<x<0 \\
1-e^{-x / \theta}, 0 \leq x \leq \infty
\end{array}\right.
$$

with the useful property that the probability that $X$ exceeds some value $x$ is given by

$$
\operatorname{Pr}(X>x)=e^{-x / \theta}
$$

when $x>0$ (Hogg and Tanis 1997).

For each class, we fit separate negative exponential functions to two distributions. The first, called the "base" estimate because the source data probably underestimated the true pattern of dispersal due to unknown distance-weighted sampling biases, was the mean value of the empirical distribution given at each distance unit in Fig. 1. This value was $\operatorname{Pr}$ (distance dispersed $>D)=e^{-(D / 1.64)}, r^{2}=0.99$ for birds, and $\operatorname{Pr}($ distance dispersed $>D)=e^{-(D / 1.5)}, r^{2}=0.99$ for mammals. The second was a "corrected" estimate of 
mean dispersal made using mean correction factors for birds and mammals based on the factors estimated for individual species by Porter and Dooley (1993). In this case, the values were, for birds, $\operatorname{Pr}$ (distance dispersed $>D)=e^{-(D / 2.6)}, r^{2}=0.94$, and, for mammals, $\operatorname{Pr}($ distance dispersed $>D)=e^{-(D / 2.06)}, r^{2}=0.96$. The resulting pairs of probability curves are shown in Fig. 5.

Fig. 5. Estimated probabilities that the minimum distance moved by dispersing birds or mammals exceeds a particular number of median distance units $(D)$ based on negativeexponential models fit to the empirical distance density data (see An Empirical Probability Model for the Minimum Distance of Dispersal). Fitted parameters are presented for "base" assumptions and for estimated distributions using distance-weighted sampling correction factors representing "corrected" assumptions. The horizontal dashed lines indicate 0.05 probabilities that dispersing juveniles will move farther than the distance indicated by the matching vertical dashed lines.

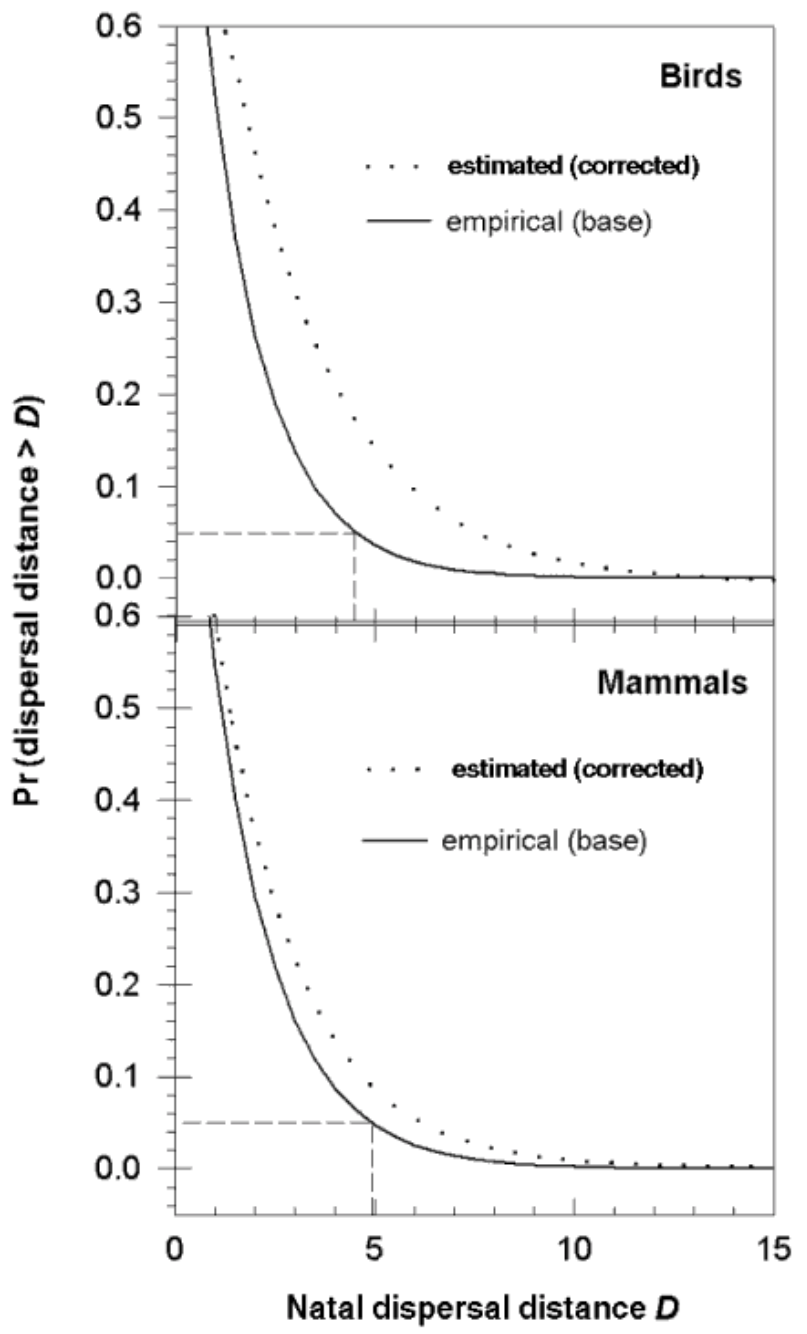

The primarily herbivorous red squirrel (Tamiasciurus hudsonicus) and the carnivorous marten (Martes americana) are good examples of how these probability models can be used in combination with allometric equations to yield estimates of the minimum probability that dispersers of selected mammal species will disperse a given distance. Female red squirrels have an average body mass of $0.199 \mathrm{~kg}$ (Appendix 1, Table A2), and the equations in Table 2 predicted median and maximum dispersal distances of 0.82 and $11.0 \mathrm{~km}$, respectively. Using the "base" probability model equation for mammals given above, we found that the estimated probability of dispersing farther than 11.33 median distance units was less than one in a thousand. By multiplying the estimate of the median distance dispersed for this species $(0.82 \mathrm{~km})$ by this estimate of the number of median distance units (11.33), we found, using our "base" assumptions, that dispersing females of this species had a small probability of settling farther than $9.29 \mathrm{~km}$. Similar calculations for marten, which has a body mass of 1.04 $\mathrm{kg}$, yielded an estimate of $40.5 \mathrm{~km}$ as the threshold distance beyond which dispersers have only a small ( $P$ $<0.001)$ probability of successfully dispersing. For marten we also had one long-distance dispersal observation of $61 \mathrm{~km}$ (Appendix 1, Table A2). Given the conservative assumptions we used, our estimate of a probable "base" threshold long-distance dispersal range for marten was, as expected, smaller than this observation. The equivalent threshold long-distance dispersal range calculated using the "corrected" probability model was $51.0 \mathrm{~km}$ for this species.

How well do the empirical minimum-probability negative exponential models predict the observed maximum extent of dispersal distances in birds and mammals? The dispersal distance data set used to estimate parameters for the empirical models (Fig. 1) did not include the maximum long-distance dispersal movement used to develop the allometric models (Figs. 2 and 3). Hence, we compared the probabilities of observing dispersal distances greater than those estimated from the empirical model with the proportion of observed maximum distances from our data that did exceed the predicted maximum distance (Fig. 6). As expected given the evidence of "fat tails" in the distributions of dispersal distances, all the models underestimated the frequency of long-distance dispersal events, i.e., all points were above the 1:1 line. This was true for both classes even when the estimated maximum extent was large enough that the predicted probability of observing even longer distances became very small. For this reason, the 
models are best applied in cases where researchers and managers wish to minimize the risk of overestimating dispersal probabilities, for example, for endangered or highly habitat-specific species.

Fig. 6. Comparison of the probabilities that dispersers would disperse farther than a given distance $(D)$, estimated using the negative-exponential models with the percentage of observed maximum dispersal distances in birds and mammals from our data that exceeded the predicted distance. Error bars represent $95 \%$ confidence intervals about the mean values, calculated using 1000 replicate bootstrap samples of the data. Separate comparisons are shown for the "base" probability models, which are represented by open symbols, and for the "corrected" probability models, which are represented by solid symbols. Also shown are the 1:1 lines indicating an identity between model predictions and observations.

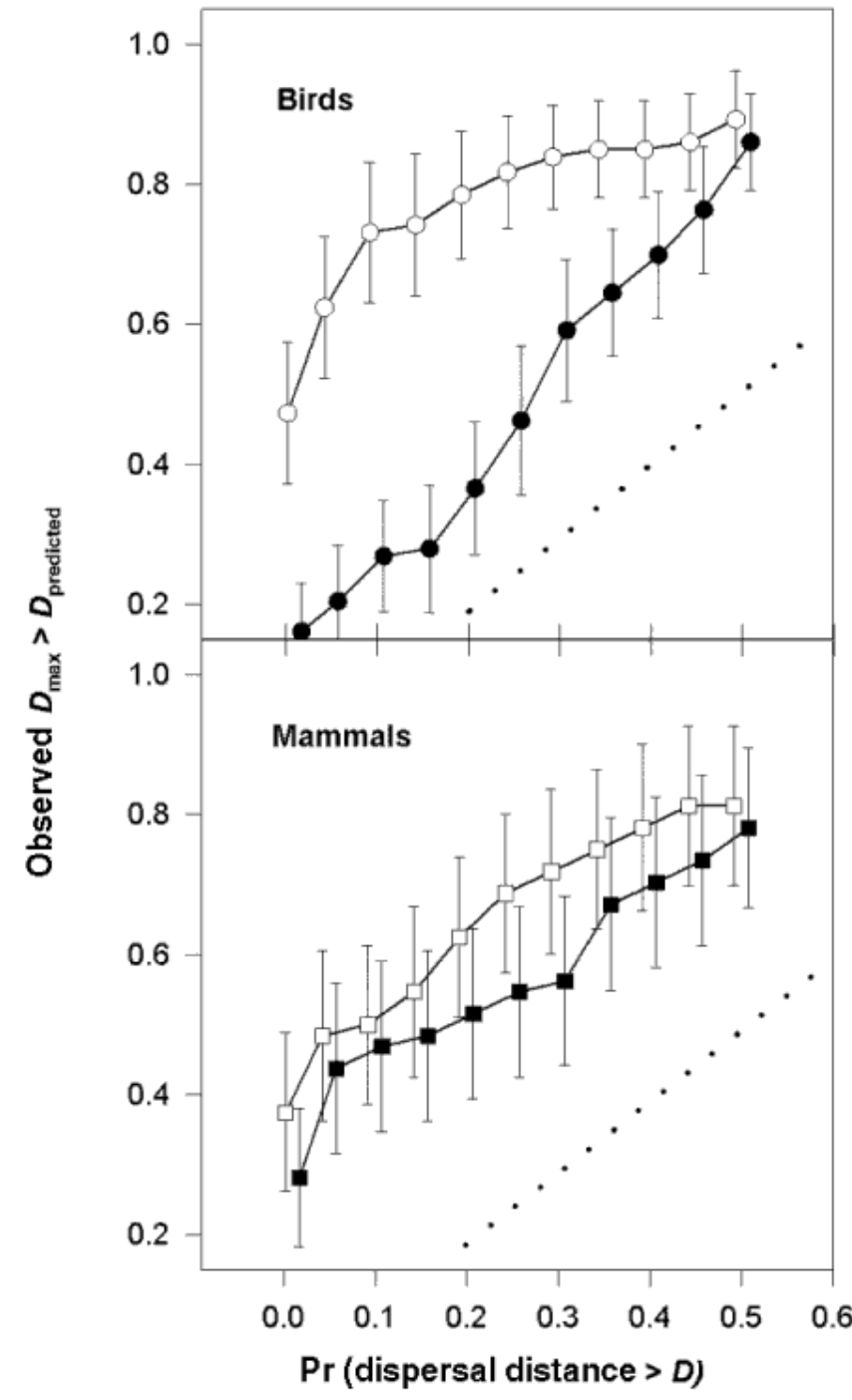

\section{DISCUSSION}

We found that a significant proportion of the variation in the distances dispersed by juvenile birds and mammals could be explained by differences in body mass and diet type, despite known differences among species in terms of reproductive ecology and movement capability. Within a class, large species dispersed farther than small species. In comparisons of bird and mammal species of similar body mass, the dispersal distances of carnivorous species were significantly longer than those of noncarnivorous species. In addition, the dispersal distances of carnivorous species of both birds and mammals grew at an increasing rate with increasing body mass. Our finding that the shapes of distributions of dispersal distances were similar among species and classes suggested that the probability of individuals dispersing different distances could be estimated even for poorly known species. For many research and management situations, it would be helpful to calculate the approximate likelihood that organisms could disperse particular distances between required habitats. One way to do this is to combine a predictive allometric relationship for estimating long distances of dispersal with a general phenomenological model for predicting the minimum probability of dispersing at least that far. We think that a primary benefit of our models lies in their ability to identify attainable distances for populations and species using easily acquired characteristics of species (attributes of diet and body mass) if detailed dispersal data are lacking. Our models can be used to identify dispersallimited species and thus focus attention on the characteristics of the landscapes needed to maintain viable populations of these species.

\section{Consequences of body size and diet type for dispersal scale}

Do patterns of natal dispersal reflect an underlying relationship among macroecological variables such as habitat productivity, patterns of resource use, and the processes that determine how far animals disperse? Among bird and mammal species, differences in the coefficients of the allometric regressions for different diet types were found to be consistent with expected differences in the density and spacing of resources. Intercepts for the equations for carnivores predicted dispersal distances over two orders of magnitude farther than those of herbivores and omnivores of equivalent body mass. The slopes of the relationships for carnivores were consistent with the $3 / 4$ scaling expected for size-dependent resource utilization 
relationships (McNab 1963, Peters 1983, West et al. 1997). Slopes for herbivores and omnivores were smaller than those for carnivores. We remain cautious, however, when relating causal processes to these statistical differences between allometric slopes, treating them instead as summary descriptions of the minimum distances of dispersal among species. We think that the complex spatial and temporal interactions that determine when animals move, their risks of mortality while dispersing, and the processes driving habitat availability must all help explain differences in dispersal patterns based on resource utilization (see also Speculation section below).

Methods of fitting allometric equations differ in their assumptions and interpretation of results. Reduced major-axis (Type II) regression provides a less biased estimate of the underlying functional relation as described by an allometric equation (LaBarbera 1989), and some authors base their allometric analyses on Type II regression (Silva 1998). Error distributions of body mass data for species were provided only occasionally in the sources we used. This prevented us from using Type II regression in most analyses. However, our primary goal was to use the equations for predicting expected dispersal distances, given body mass and other criteria. For this purpose, Type I regression was appropriate (LaBarbera 1989).

The spatial scale of dispersal is a primary determinant of its functional role in the dynamics of populations, even in sedentary species of birds (Koenig et al. 1996, Martin 1998). The frequency distribution of dispersal distances is key to calculating the probability that individuals can move through a given landscape (Merriam 1998). Our models can be used to estimate minimum threshold values of the likelihood that dispersing individuals can move particular distances. Despite the assumptions in our models, we think that they can be used to generate distributions of dispersal distances for species whose dispersal parameters are poorly known. Our models have heuristic value in estimating minimum distances between suitable habitats for selected species, e.g., conservatively, female red squirrels ( $T$. hudsonicus) have a strong probability $(P<0.001)$ of successfully dispersing at least $9.2 \mathrm{~km}$, whereas marten (M. americana) have the same probability of successfully dispersing at least $40.5 \mathrm{~km}$; details of these calculations are provided in the Results section. However, our models cannot be used to calculate directly the rates at which species could expand their ranges. Rare, long-distance dispersal events influence the overall pattern and scale of dispersal in both birds and mammals. For example, the leptokurtic, fat-tailed shapes of the distributions in Table 1 suggest highly variable dispersal distances among individuals of a given species, with a few individuals dispersing long distances relative to the median of the population. Such rare long-distance events are difficult to observe but are important for the spread of species (Kot et al. 1996), as well as for preventing inbreeding in small populations (Mills and Allendorf 1996). Simple probability density models such as the negative exponential, while capturing the average behavior of the population of dispersers, significantly underestimate the potential for range expansion in many organisms (Kot et al. 1996).

By examining the predictive nature of intra- and interspecific patterns of dispersal distances in both birds and mammals, we can extend results from other research. Earlier work by Peters (1983) found positive relationships among body mass, speed of locomotion, and maximum distance of migration for both birds and mammals. The general allometric patterns that we obtained for measures of natal dispersal in mammals are similar to those obtained by Van Vuren (1998) for median dispersal distances of 40 species of North America mammals and by J. O. Wolff (unpublished data) for long-distance movements in 74 species of mammals. We obtained slightly shorter median dispersal distances for herbivorous mammals than did Van Vuren (1998), although the differences are within 95\% confidence intervals as calculated from his results. In their analysis of natal dispersal patterns in 75 terrestrial bird species in the UK, Paradis et al. (1998) found that body mass was a significant covariate of mean and median dispersal distances, but they did not attempt to develop predictive relationships. Body mass, diet type, and other factors, in part, determine dispersal distance. Thus, these factors assist in linking broad population-level consequences of dispersal (e.g., lifetime fitness, probabilities of habitat occupancy, genetic relatedness) with life-history attributes of species and their needs for resources, including the distribution and availability of these resources within and among habitats (Brown and Maurer 1989, Holling 1992, Martin 1998). Specific predictions about the dispersalmediated consequences to population dynamics that are created by future perturbations of habitats are less easy to develop using our results. Factors such as density-dependent effects on dispersal rates, mortality risks, and the availability of unoccupied areas in habitats result from interactions among behavioral processes below our level of analysis. 


\section{Life-history correlates of dispersal scale}

We were surprised to find little evidence that the median or maximum distances of natal dispersal in birds or mammals were related to broad categories of life-history strategies. Only in birds were taxonomic relatedness and migratory status found to be related to maximum distance dispersed. In general, our findings paralleled those of Paradis et al. (1998) despite the differences in our statistical approach. Of particular interest are the differences in dispersal distances between migratory and resident bird species, with the former dispersing farther. Resident species probably incur different costs and benefits from dispersing than do long-distance migrant species (e.g., neotropical or transequatorial migrants) and may be less opportunistic in their choice of a site at which to settle (Paradis et al. 1998). However, our questionable ability to separate postfledging exploratory movements (including dispersal) from migratory movements in our data renders this interpretation provisional. Furthermore, our tests are generally not very effective at distinguishing putative differences in dispersal patterns attributable to other life-history factors (range of $\beta: 0.05-0.48)$. We therefore suggest that allometric scaling of dispersal among species as presented in our study should be viewed primarily as representing synthetic relationships that integrate many, sometimes conflicting, fine-scale behavioral and ecological processes rather than indicating their lack of relevance.

Several syntheses showed that dispersal rates and distances were often male-biased in mammals and female-biased in birds (Greenwood 1980, Wolff 1993, Clarke et al. 1997). In our analysis, evidence of a distinction in median or maximum dispersal distances between sexes of the same species was too weak to make it worthwhile to treat the genders separately. Possible explanations for our failure to detect expected differences between genders in median and maximum distances include small sample sizes (only 16 species of birds and eight of species of mammals met our data criteria), high variance (in part, because observations of maximum distances dispersed by individual animals are often serendipitous), and the fact that our dispersal data did not come from a random sample of species. Bird species dispersed much farther than mammal species of equivalent body mass for both median and maximum dispersal distances. This result is intuitive, because birds are more vagile than nonvolant mammals.

It was even more surprising that we did not find evidence that the range of variation in median or maximum dispersal distances was greater for birds than for mammals, after accounting for body mass and diet type. It is possible that differences in researchers' ability to detect dispersing birds and mammals may have confounded this result. However, not only did we fail to find a detectable effect of observation method (e.g., radiotelemetry, band-resight, etc.) on the residual variation about the regressions, but we also screened both sets of data to ensure that the effects of small study areas were reduced or eliminated. This apparent similarity in range of variation for dispersal distances between the two classes may reflect interclass similarity in types of interactions between dispersing animals and their environment that determine their probability of settling. Our inability to separate clearly the effects of physiological limits, mortality factors, and variation of habitat quality on the scale of dispersal constrains our ability to infer how those interactions might operate.

Martin (1998) posed basic questions about patterns of dispersal: "how, where, how far, when." Our interspecific study identified predictive relationships underlying the "how far" question. However, other data are needed from species-specific studies of dispersal. From our perspective of dispersal processes and landscape design, an important gap in knowledge is the lack of information about the survivorship of dispersing animals. Simulations by Henein and Merriam (1990) showed the potential importance of survivorship during dispersal movements, and there are empirical data from several studies involving the dwarf mongoose, Helogale parvula (Waser et al. 1994), the Blue-breasted Fairy Wren, Malurus pulcherrimus, and the White-browed Babbler, Pomatostomus superciliosus (Brooker et al. 1999), and the Northern Spotted Owl, Strix occidentalis (Miller et al. 1997). However, studies of dispersal in several grouse species did not indicate a significant survival cost to dispersing juveniles (Martin 1998). We agree with Merriam (1998) that studies of habitat-specific survivorship during dispersal periods are required to assess rates of exchange between fragments in landscape-habitat models.

\section{SPECULATION}

In many vertebrates, body mass is closely correlated with ecological variables that affect the allocation of space and nutritional resources, e.g., home range area (McNab 1963, Harestad and Bunnell 1979, Holling 1992), local population density (Silva and Downing 
1995b), and geographic range (Brown and Maurer 1989). We recognize that there are still substantial problems related to the derivation, interpretation, and predictive power of allometric scaling when applying it to interspecific ecological analyses.

First, whereas allometric relationships provide a concise description of the percentage changes of one structural character (usually body mass) with other life-history characteristics, their functional interpretation remains unclear. At root, this uncertainty is founded upon the question of whether a pervasive causal process underlies allometric patterns or whether interspecific allometries arise as mere statistical epiphenomena out of syntheses of intraspecific patterns (Cates and Gittleman 1997). On the one hand, West et al. (1997) propose that constraints on energy allocation within and among organisms in a phylogeny are the fundamental explanation for interspecific allometric relationships (including macroecological ones such as home range size and patterns of population density). On the other, Koslowski and Weiner (1997) argue that, because the target of evolution is individual variation within a species, interspecific patterns may combine different evolutionary solutions to the problem of energy allocation. Consequently, they think that interspecific allometries have only weak biological significance.

Second, analytical methods for calculating allometric exponents can be biased (LaBarbera 1989), particularly in their assumption that the processes being compared are similar across the taxa and body mass ranges under consideration (Prothero 1986). Thus, inferences about the meaning of exponents relating ecological patterns to body mass must carefully consider whether underlying processes are truly comparable among the species included (Holling 1992).

Third, by the nature of their derivation, scaling relationships (e.g., exponents) have little capability to discriminate across the broad classes of stochastic or conditionally stochastic processes that generated them. Additionally, because they are implicitly conditional (i.e., they arise from studies conducted under specific conditions), using them to forecast patterns is problematic if future conditions are expected to differ substantially from those under which the original relationships evolved.

Despite these difficulties, broad cross-taxon relationships reveal characteristics of processes that are not always apparent from studies of individual species. If the ultimate evolutionary function of dispersal is to improve reproductive success (Sinclair 1992) and if interspecific allometric relationships capture the responses of species to patterns of resource availability at different scales (Holling 1992), then a species' dispersal capability may be linked to the spatial and temporal grain as well as the extent of the resources required for survival and reproduction. Generally, interpretations of an animal's areal decisions about utilization of resources are related to the density of resources at the scales of individual foraging items, patches, and their seasonal integration at the larger scale of a home range (Holling 1992, Peterson et al. 1998). Our finding of structurally similar relationships between body mass and the spatial scale of dispersal in birds and mammals suggests that an individual's dispersal decisions have a similar ecological basis, serving to locate the animal in habitats that are likely to provide resources needed for its long-term reproductive success. We suggest that, at the large spatial and long time scales of dispersal phenomena, the summary properties of dispersal processes that determine their spatial extent may be derived from interactions between behavioral and morphological variables of species and their linkages to the dynamics of resource availability in landscapes.

The results of our study can be used to develop and assess potential solutions for problems involving habitat management and landscape planning. We suggest two broad types of applications and offer examples from forests. First, the basic parameters of the frequency-distance distributions are fundamental to assessing the potential effects of habitat loss and fragmentation on selected species. Many conservation issues involve natal dispersal because it is a primary mechanism for colonization and genetic exchange between populations (Hedrick 1996). As well, population declines in many species have been linked directly to loss and fragmentation of habitats (Robinson et al. 1992) and indirectly to reduced interpatch dispersal (Whitcomb et al. 1981, Fahrig and Merriam 1985, Doak et al. 1992, Pulliam et al. 1992, Lamberson et al. 1994, Schumaker 1996). For species in which preserving key habitats is a management priority, researchers and managers can combine the allometric equations with the probability model to help assess the ability of alternative configurations of habitat patches to provide adequate connectedness among populations (Van Vuren 1998).

Managers must have a knowledge of dispersal because 
it is a critical variable for modeling the effects of landscape change on the long-term viability of metapopulations (Beissinger and Westphal 1998). Concerns about habitat fragmentation and landscape design are based, in part, on the ability of wildlife to disperse between the blocks of habitat types that they require (Schumaker 1996, Fahrig 1997). Long-term population declines of forest-dependent species are thought to occur because large-scale forest harvesting changes habitats by destroying old-growth forest, reducing the number of areas of contiguous mature forest, and eliminating many structural components in stands (Bunnell and Kremsater 1990, Hansen et al. 1991, Spies et al. 1994). Forestry practices can alter and fragment habitats over spatial and temporal scales important for population survival, e.g., $10 \mathrm{~m}-1000 \mathrm{~km}$ and 1 month-1 century (Bunnell and Huggard 1999). These scales place a priority on identifying the equivalent extent of population movements that will reduce the risk of population loss. Our study provides estimates of dispersal distances and can be used to predict the effects of fragmentation and alteration of habitats on individual species.

The second broad type of application is at the level of communities in managed landscapes. Our results can be used to help identify dispersal-limited species that may face long-term risks from large-scale habitat alterations. The allometric relationships that we present can be used to estimate dispersal distances for each species of bird and mammal in a community and assess their potential vulnerability to fragmentation based on dispersal capability. Loss and fragmentation of forests, especially late-seral stands, is touted as a critical issue in the management of temperate forests (Lehmkuhl and Ruggiero 1991). Predicting the effects of habitat changes due to forest practices on communities is contentious because of the biological interdependence of forest ecosystems; forestry and land-use practices create several changes simultaneously (Bunnell 1999). To meet the habitat needs of the community of species dwelling in lateseral stands, managers must consider the amount of late-seral forest that is retained, the size of forest patches, and the distances between forest patches. It is difficult to optimize the spatial distribution of later seral forests for the suite of species that depends on them because of the complex relationship between habitat area, patch size, and distance between patches (Harris 1984). Our models can be used as a planning filter for assigning priorities to conservation initiatives and more directly evaluating management options for these vulnerable species. By examining dispersal capability among the species of a community, members of the community can be identified that are potentially more vulnerable to habitat fragmentation than others. Such analyses can be used to plan landscapes of managed forests over the long term, supporting frequently used theoretical arguments for the inclusion of broad-scale movement patterns in the management of wildlife habitat (Schumaker 1996, Beissinger and Westphal 1998). By combining information on patch size with data on distances between patches, forest managers can determine which forest-dwelling species are vulnerable in existing and future landscapes.

Modeling of dispersal distances is useful at the scale of landscapes in assessing the connectedness between habitats for the species and populations they host. Such analyses must include detailed species-specific habitat relationships (Brooker et al. 1999). Besides fragmentation, managers should consider processes that occur within the matrix between habitat fragments. The number of individuals dispersing a particular distance depends on the survivorship of dispersing animals as they travel through this matrix. However, there is little information on the landscape features that increase the risks of mortality for dispersing animals (Beissinger and Westphal 1998). To facilitate dispersal and reduce risks to vulnerable species, it is essential to maintain the quality of the habitat encountered by dispersing animals. Two key questions are central to issues of forest fragmentation: how hostile is the intervening habitat to a species and for how long is it hostile? In forest landscapes modified by logging, managers could decrease the "hostility" of the matrix by maintaining structural heterogeneity within cutblocks (Franklin et al. 1997). By providing suitable cover in cutblocks, survivorship of dispersing individuals could increase, which would enhance dispersal between fragments. Appropriate silvicultural practices in the matrix between forest fragments could reduce the vulnerability of species to habitat fragmentation.

Responses to this article can be read online at: http://www.consecol.org/vol4/iss1/art16/responses/index.html.

\section{Acknowledgments:}

We thank Fred Bunnell, Dave Daust, Glen Dunsworth, Sue Glenn, David Huggard, Kathy Martin, Doug Runde, and Ian Thompson for helpful discussions during the development of this paper. Fred Bunnell, Clay Elder, Neil Surrey, and Elke 
Wind assisted us with the literature search. Comments by the Forest Ecology Group at SFU, Sue Glenn, David Huggard, C. S. Holling, Phil Taylor, and three anonymous reviewers greatly improved earlier versions of the manuscript. Research funding was provided by a Forestry
Canada Green Plan research grant to ASH, KL, and Fred Bunnell, as well as Forest Renewal British Columbia, and an EcoResearch Doctoral Fellowship to GDS. This is research contribution R-33 from the Centre for Applied Conservation Biology.

\section{APPENDIX 1}

Sources of dispersal data for birds (Table A1) and mammals (Table A2) used for analysis. Species are listed in taxonomic order. For each study, the type of data extracted is coded as "S" (single observation only-generally a maximum natal dispersal distance) or "D" (distance-density distribution). Categorical life-history variables shown here are: (1) diet type: $\mathrm{H}$, herbivore; O, omnivore; $\mathrm{C}$, carnivore; (2) social system in breeding season: $\mathrm{T}$, territorial; N, non-exclusive territories or neighborhood; G, gregarious; and (3) migratory status of the population or species: M, migratory; R, non-migratory. If sample sizes $(n)$ are given, they refer to the number of dispersing animals meeting our criteria that were reported in the study; otherwise, a " ... " is given. Where possible, data for males (m) and females (f) are shown separately. Data from studies in which the sexes were not differentiated are indicated by "m/f."

\section{Table A1. Birds}

\begin{tabular}{|c|c|c|c|c|c|c|c|c|c|}
\hline Species & $\begin{array}{c}\text { Body } \\
\text { mass }(k g)\end{array}$ & $\begin{array}{l}\text { Obs } \\
\text { type }\end{array}$ & $\begin{array}{c}\text { Natal } \\
\text { dispersal } \\
\text { median } \\
\text { distance } \\
(\mathbf{k m})\end{array}$ & $\begin{array}{c}\text { Natal } \\
\text { dispersal } \\
\text { maximum } \\
\text { distance } \\
(\mathbf{k m})\end{array}$ & $\mathbf{1}$ & 2 & 3 & $n$ & Source \\
\hline $\begin{array}{l}\text { Phalacrocorax } \\
\text { pelagicus }\end{array}$ & $\begin{array}{l}2.03 \mathrm{~m} \\
1.7 \mathrm{f}\end{array}$ & $S$ & $\ldots$ & $150.0 \mathrm{~m} / \mathrm{f}$ & $\mathrm{C}$ & G & M & $\ldots$ & Hobson (1997) \\
\hline Cygnus olor & $\begin{array}{l}11.80 \mathrm{~m} \\
9.67 \mathrm{f}\end{array}$ & $S$ & $\ldots$ & $64.0 \mathrm{~m} / \mathrm{f}$ & $\mathrm{H}$ & $\mathrm{T}$ & $\mathrm{R}$ & $\ldots$ & Ciaranca et al. (1997) \\
\hline $\begin{array}{l}\text { Cygnus } \\
\text { buccinator }\end{array}$ & $\begin{array}{l}11.40 \mathrm{~m} \\
10.30 \mathrm{f}\end{array}$ & $S$ & $\ldots$ & $128.0 \mathrm{~m} / \mathrm{f}$ & $\mathrm{O}$ & $\mathrm{T}$ & M & $\ldots$ & Mitchell (1994) \\
\hline $\begin{array}{l}\text { Branta } \\
\text { canadensis }\end{array}$ & $\begin{array}{l}3.814 \mathrm{~m} \\
3.314 \mathrm{f}\end{array}$ & $\mathrm{D}$ & $\begin{array}{c}2.0 \mathrm{~m} \\
1.5 \mathrm{f}\end{array}$ & $\begin{array}{c}28.4 \mathrm{~m} \\
11.2 \mathrm{f}\end{array}$ & $\mathrm{H}$ & $\mathrm{T}$ & $\mathrm{R}$ & $\begin{array}{l}19 \mathrm{~m} \\
20 \mathrm{f}\end{array}$ & Lessells (1985) \\
\hline Aix sponsa & $\begin{array}{l}0.681 \mathrm{~m} \\
0.685 \mathrm{f}\end{array}$ & S & ... & $3.8 \mathrm{~m} / \mathrm{f}$ & $\mathrm{O}$ & $\mathrm{N}$ & M & $\ldots$ & $\begin{array}{l}\text { Hepp and Bellrose } \\
\text { (1995) }\end{array}$ \\
\hline $\begin{array}{l}\text { Bucephala } \\
\text { clangula }\end{array}$ & $\begin{array}{l}1.00 \mathrm{~m} \\
0.80 \mathrm{f}\end{array}$ & $\mathrm{D}$ & $0.75 \mathrm{f}$ & $6.0 \mathrm{f}$ & $\mathrm{O}$ & $\mathrm{N}$ & M & $138 \mathrm{f}$ & $\begin{array}{l}\text { Dow and Fredga } \\
\text { (1983) }\end{array}$ \\
\hline $\begin{array}{l}\text { Bucephala } \\
\text { albeola }\end{array}$ & $0.334 \mathrm{f}$ & $S$ & $\ldots$ & $4.5 \mathrm{f}$ & $\mathrm{C}$ & $\mathrm{T}$ & M & $\ldots$ & Gauthier (1993) \\
\hline $\begin{array}{l}\text { Lophodytes } \\
\text { cucullatus }\end{array}$ & $\begin{array}{c}0.68 \mathrm{~m} \\
0.54 \mathrm{f}\end{array}$ & $S$ & $\ldots$ & $5.6 \mathrm{~m} / \mathrm{f}$ & $\mathrm{C}$ & $\mathrm{T}$ & M & $10 \mathrm{f}$ & Dugger et al. (1994) \\
\hline $\begin{array}{l}\text { Eudocimus } \\
\text { albus }\end{array}$ & $\begin{array}{l}1.04 \mathrm{~m} \\
0.76 \mathrm{f}\end{array}$ & $S$ & ... & $100.0 \mathrm{~m} / \mathrm{f}$ & $\mathrm{C}$ & G & M & ... & $\begin{array}{c}\text { Kushlan and Bildstein } \\
\text { (1992) }\end{array}$ \\
\hline Elanus leucurus & $0.325 \mathrm{~m} / \mathrm{f}$ & $S$ & $\ldots$ & $160.0 \mathrm{~m} / \mathrm{f}$ & $\mathrm{C}$ & $\mathrm{N}$ & $\mathrm{R}$ & $\ldots$ & Dunk (1995) \\
\hline
\end{tabular}




\begin{tabular}{|c|c|c|c|c|c|c|c|c|c|}
\hline $\begin{array}{l}\text { Accipiter } \\
\text { gentilis }\end{array}$ & $\begin{array}{l}0.912 \mathrm{~m} \\
1.137 \mathrm{f}\end{array}$ & $\mathrm{D}$ & $\begin{array}{l}32 \mathrm{~m} \\
17 \mathrm{f}\end{array}$ & $1150 \mathrm{~m} / \mathrm{f}$ & $\mathrm{C}$ & $\mathrm{T}$ & M & $\begin{array}{l}87 \mathrm{~m} \\
66 \mathrm{f}\end{array}$ & $\begin{array}{c}\text { Marcström and } \\
\text { Kenward (1981), } \\
\text { Mueller and Berger } \\
\text { (1967) }\end{array}$ \\
\hline $\begin{array}{l}\text { Accipiter } \\
\text { cooperi }\end{array}$ & $\begin{array}{c}0.349 \mathrm{~m} \\
0.529 \mathrm{f}\end{array}$ & $\mathrm{D}$ & $\begin{array}{l}9.2 \mathrm{~m} \\
14.4 \mathrm{f}\end{array}$ & $35.2 \mathrm{~m}$ & $\mathrm{C}$ & $\mathrm{T}$ & M & $6 \mathrm{~m}$ & $\begin{array}{l}\text { Rosenfield and } \\
\text { Bielefeldt (1992) }\end{array}$ \\
\hline Accipiter nisus & $\begin{array}{c}0.150 \mathrm{~m} \\
0.280 \mathrm{f}\end{array}$ & $\mathrm{D}$ & $\begin{array}{l}9.0 \mathrm{~m} \\
18.5 \mathrm{f}\end{array}$ & $\begin{array}{l}108.0 \mathrm{~m} \\
166.0 \mathrm{f}\end{array}$ & $\mathrm{C}$ & $\mathrm{T}$ & $\mathrm{R}$ & $\begin{array}{l}99 \mathrm{~m} \\
65 \mathrm{f}\end{array}$ & $\begin{array}{l}\text { Newton and Marquiss } \\
\text { (1983) }\end{array}$ \\
\hline $\begin{array}{l}\text { Parabuteo } \\
\text { unicinctus }\end{array}$ & $\begin{array}{l}0.69 \mathrm{~m} \\
0.99 \mathrm{f}\end{array}$ & $\mathrm{S}$ & $\cdots$ & $160.0 \mathrm{~m} / \mathrm{f}$ & $\mathrm{C}$ & $\mathrm{N}$ & $\mathrm{R}$ & $\ldots$ & Bednarz (1995) \\
\hline Buteo lineatus & $\begin{array}{c}0.475 \mathrm{~m} \\
0.643 \mathrm{f}\end{array}$ & $\mathrm{S}$ & $\cdots$ & $24.0 \mathrm{~m} / \mathrm{f}$ & $\mathrm{C}$ & $\mathrm{T}$ & M & $4 \mathrm{~m} / \mathrm{f}$ & Crocoll (1994) \\
\hline $\begin{array}{l}\text { Buteo } \\
\text { swainsoni }\end{array}$ & $1.069 \mathrm{f}$ & $S$ & $\ldots$ & $320.0 \mathrm{f}$ & $\mathrm{C}$ & $\mathrm{T}$ & M & $46 \mathrm{~m} / \mathrm{f}$ & $\begin{array}{c}\text { Preston and Beane } \\
\text { (1993) }\end{array}$ \\
\hline $\begin{array}{l}\text { Aquila } \\
\text { adalberti }\end{array}$ & $3.0 \mathrm{~m} / \mathrm{f}$ & $\mathrm{D}$ & $100.0 \mathrm{~m} / \mathrm{f}$ & $430.0 \mathrm{~m} / \mathrm{f}$ & $\mathrm{C}$ & $\mathrm{T}$ & $\mathrm{R}$ & $24 \mathrm{~m} / \mathrm{f}$ & Ferrer (1993) \\
\hline $\begin{array}{l}\text { Falco } \\
\text { peregrinus }\end{array}$ & $\begin{array}{l}0.611 \mathrm{~m} \\
0.952 \mathrm{f}\end{array}$ & $\mathrm{D}$ & $\begin{array}{l}58.0 \mathrm{~m} \\
83.0 \mathrm{f}\end{array}$ & $\begin{array}{l}357.0 \mathrm{~m} \\
324.0 \mathrm{f}\end{array}$ & $\mathrm{C}$ & $\mathrm{T}$ & $\mathrm{R}$ & $11 \mathrm{~m}$ & $\begin{array}{l}\text { Mearns and Newton } \\
\text { (1982), James et al. } \\
\text { (1989) }\end{array}$ \\
\hline $\begin{array}{l}\text { Falco } \\
\text { sparverius }\end{array}$ & $\begin{array}{l}0.111 \mathrm{~m} \\
0.120 \mathrm{f}\end{array}$ & $\mathrm{D}$ & $\begin{array}{l}4.8 \mathrm{~m} \\
5.06 \mathrm{f}\end{array}$ & $\begin{array}{l}32.45 \mathrm{~m} \\
38.79 \mathrm{f}\end{array}$ & $\mathrm{C}$ & $\mathrm{T}$ & M & $21 \mathrm{f}$ & $\begin{array}{l}\text { Miller and Smallwood } \\
\text { (1997) }\end{array}$ \\
\hline Bonasa bonasia & $\cdots$ & $S$ & $\cdots$ & $\begin{array}{l}5.7 \mathrm{~m} \\
4.8 \mathrm{f}\end{array}$ & $\mathrm{H}$ & $\mathrm{N}$ & $\mathrm{R}$ & $9 \mathrm{~m} / \mathrm{f}$ & Fang and Sun (1997) \\
\hline $\begin{array}{l}\text { Dendragapus } \\
\text { canadensis }\end{array}$ & $\begin{array}{l}0.492 \mathrm{~m} \\
0.456 \mathrm{f}\end{array}$ & $\mathrm{D}$ & $\begin{array}{l}0.6 \mathrm{~m} \\
5.0 \mathrm{f}\end{array}$ & $\begin{array}{l}6.0 \mathrm{~m} \\
6.0 \mathrm{f}\end{array}$ & $\mathrm{H}$ & $\mathrm{T}$ & M & $88 \mathrm{~m}$ & $\begin{array}{c}\text { Hines (1986), } \\
\text { Schroeder (1986) }\end{array}$ \\
\hline $\begin{array}{l}\text { Dendragapus } \\
\text { obscurus }\end{array}$ & $\begin{array}{l}1.188 \mathrm{~m} \\
0.891 \mathrm{f}\end{array}$ & $\mathrm{D}$ & $\begin{array}{l}0.9 \mathrm{~m} \\
1.4 \mathrm{f}\end{array}$ & $\begin{array}{l}2.6 \mathrm{~m} \\
11.0 \mathrm{f}\end{array}$ & $\mathrm{H}$ & $\mathrm{T}$ & $\mathrm{R}$ & $\begin{array}{l}24 \mathrm{~m} \\
42 \mathrm{f}\end{array}$ & $\begin{array}{l}\text { Beaudette and Keppie } \\
\text { (1992), Jamieson and } \\
\text { Zwickel (1983) }\end{array}$ \\
\hline $\begin{array}{l}\text { Tympanuchus } \\
\text { cupido }\end{array}$ & $\begin{array}{l}0.999 \mathrm{~m} \\
0.772 \mathrm{f}\end{array}$ & $\mathrm{D}$ & $1.0 \mathrm{~m} / \mathrm{f}$ & $10.8 \mathrm{~m} / \mathrm{f}$ & $\mathrm{H}$ & $\mathrm{N}$ & M & $24 \mathrm{~m} / \mathrm{f}$ & $\begin{array}{c}\text { Bowman and Robel } \\
\text { (1977) }\end{array}$ \\
\hline $\begin{array}{l}\text { Meleagris } \\
\text { gallopavo }\end{array}$ & $\begin{array}{l}7.40 \mathrm{~m} \\
4.22 \mathrm{f}\end{array}$ & S & $\ldots$ & $48.0 \mathrm{f}$ & $\mathrm{O}$ & $\mathrm{N}$ & $\mathrm{R}$ & ... & Eaton (1992) \\
\hline $\begin{array}{l}\text { Lagopus } \\
\text { leucurus }\end{array}$ & $\begin{array}{l}0.359 \mathrm{~m} \\
0.516 \mathrm{f}\end{array}$ & $\mathrm{D}$ & $\begin{array}{l}1.0 \mathrm{~m} \\
4.0 \mathrm{f}\end{array}$ & $\begin{array}{l}7.5 \mathrm{~m} \\
29.0 \mathrm{f}\end{array}$ & $\mathrm{H}$ & $\mathrm{T}$ & $\mathrm{R}$ & $\begin{array}{c}258 \mathrm{~m} \\
68 \mathrm{f}\end{array}$ & $\begin{array}{c}\text { Giesen and Braun } \\
\text { (1993) }\end{array}$ \\
\hline $\begin{array}{l}\text { Lagopus } \\
\text { lagopus }\end{array}$ & $\begin{array}{l}0.601 \mathrm{~m} \\
0.516 \mathrm{f}\end{array}$ & $\mathrm{D}$ & $\begin{array}{l}1.0 \mathrm{~m} \\
2.9 \mathrm{f}\end{array}$ & $\begin{array}{l}4.0 \mathrm{~m} \\
7.5 \mathrm{f}\end{array}$ & $\mathrm{H}$ & $\mathrm{T}$ & $\mathrm{R}$ & $\begin{array}{l}60 \mathrm{~m} \\
17 \mathrm{f}\end{array}$ & $\begin{array}{l}\text { Martin and Hannon } \\
\text { (1987) }\end{array}$ \\
\hline $\begin{array}{l}\text { Actitis } \\
\text { macularia }\end{array}$ & $\begin{array}{l}0.477 \mathrm{~m} \\
0.394 \mathrm{f}\end{array}$ & $\mathrm{S}$ & $\ldots$ & $146.7 \mathrm{~m} / \mathrm{f}$ & $\mathrm{C}$ & $\mathrm{T}$ & $\mathrm{P}$ & $5 \mathrm{~m} / \mathrm{f}$ & Oring et al. (1997) \\
\hline $\begin{array}{l}\text { Numenius } \\
\text { phaeopus }\end{array}$ & $\begin{array}{l}0.36 \mathrm{~m} \\
0.40 \mathrm{f}\end{array}$ & $S$ & $\ldots$ & $1.63 \mathrm{~m}$ & $\mathrm{O}$ & $\mathrm{N}$ & M & $\ldots$ & $\begin{array}{c}\text { Skeel and Mallory } \\
\text { (1996) }\end{array}$ \\
\hline $\begin{array}{l}\text { Recurvirostra } \\
\text { americana }\end{array}$ & $0.32 \mathrm{~m} / \mathrm{f}$ & $\mathrm{S}$ & $\ldots$ & $19.4 \mathrm{f}$ & $\mathrm{O}$ & G & M & $\begin{array}{l}5 \mathrm{~m} \\
3 \mathrm{f}\end{array}$ & $\begin{array}{l}\text { Robinson and Oring } \\
\text { (1997) }\end{array}$ \\
\hline
\end{tabular}




\begin{tabular}{|c|c|c|c|c|c|c|c|c|c|}
\hline $\begin{array}{l}\text { Charadrius } \\
\text { melodus }\end{array}$ & $0.552 \mathrm{~m} / \mathrm{f}$ & $\mathrm{D}$ & $11.8 \mathrm{~m} / \mathrm{f}$ & $\begin{array}{c}596.0 \mathrm{~m} \\
146 \mathrm{f}\end{array}$ & $\mathrm{C}$ & $\mathrm{T}$ & M & $34 \mathrm{~m} / \mathrm{f}$ & Haig and Oring (1988) \\
\hline $\begin{array}{l}\text { Larus } \\
\text { delawarensis }\end{array}$ & $\begin{array}{l}0.57 \mathrm{~m} \\
0.47 \mathrm{f}\end{array}$ & $\mathrm{D}$ & $98.0 \mathrm{~m} / \mathrm{f}$ & $700 \mathrm{~m} / \mathrm{f}$ & $\mathrm{O}$ & $\mathrm{G}$ & M & $\begin{array}{l}2427 \\
\mathrm{~m} / \mathrm{f}\end{array}$ & Gabrey (1996) \\
\hline $\begin{array}{l}\text { Larus } \\
\text { glaucescens }\end{array}$ & $1.010 \mathrm{~m} / \mathrm{f}$ & $\mathrm{D}$ & $100.0 \mathrm{~m} / \mathrm{f}$ & $400.0 \mathrm{~m} / \mathrm{f}$ & $\mathrm{C}$ & G & $\mathrm{R}$ & $\begin{array}{l}581 \\
\mathrm{~m} / \mathrm{f}\end{array}$ & $\begin{array}{c}\text { Butler et al. (1980), } \\
\text { Belant and Dolbeer } \\
\text { (1993) }\end{array}$ \\
\hline Larus fuscus & $0.71 \mathrm{~m} / \mathrm{f}$ & $\mathrm{D}$ & $42 \mathrm{~m} / \mathrm{f}$ & $202 \mathrm{~m} / \mathrm{f}$ & $\mathrm{C}$ & G & $\mathrm{R}$ & $\begin{array}{c}1836 \\
\mathrm{~m} / \mathrm{f}\end{array}$ & Paradis et al. (1998) \\
\hline $\begin{array}{l}\text { Columba } \\
\text { palumbus }\end{array}$ & $0.49 \mathrm{~m} / \mathrm{f}$ & $\mathrm{D}$ & $4 \mathrm{~m} / \mathrm{f}$ & $150 \mathrm{~m} / \mathrm{f}$ & $\mathrm{O}$ & $\mathrm{T}$ & $\mathrm{R}$ & $\begin{array}{l}751 \\
\mathrm{~m} / \mathrm{f}\end{array}$ & Paradis et al. (1998) \\
\hline $\begin{array}{l}\text { Zenaida } \\
\text { macroura }\end{array}$ & $\begin{array}{c}0.123 \mathrm{~m} \\
0.115 \mathrm{f}\end{array}$ & $S$ & $\ldots$ & $\begin{array}{l}4.8 \mathrm{~m} \\
4.8 \mathrm{f}\end{array}$ & $\mathrm{H}$ & $\mathrm{N}$ & M & $\ldots$ & $\begin{array}{l}\text { Tomlinson et al. } \\
\text { (1960) }\end{array}$ \\
\hline Otus asio & $\begin{array}{c}0.167 \mathrm{~m} \\
0.194 \mathrm{f}\end{array}$ & $\mathrm{D}$ & $10.7 \mathrm{~m} / \mathrm{f}$ & $158.5 \mathrm{~m} / \mathrm{f}$ & $\mathrm{C}$ & $\mathrm{N}$ & $\mathrm{R}$ & $17 \mathrm{~m} / \mathrm{f}$ & $\begin{array}{c}\text { Belthoff and Ritchison } \\
\text { (1989), VanCamp and } \\
\text { Henny (1975), } \\
\text { Gehlbach (1986) }\end{array}$ \\
\hline Strix aluco & $\begin{array}{l}0.454 \mathrm{~m} \\
0.478 \mathrm{f}\end{array}$ & $\mathrm{D}$ & $4.0 \mathrm{~m} / \mathrm{f}$ & $22.4 \mathrm{~m} / \mathrm{f}$ & $\mathrm{C}$ & $\mathrm{T}$ & $\mathrm{R}$ & $9 \mathrm{~m} / \mathrm{f}$ & Southern (1970) \\
\hline Strix nebulosa & $\begin{array}{l}0.79 \mathrm{~m} \\
1.16 \mathrm{f}\end{array}$ & $S$ & $\ldots$ & $50.0 \mathrm{~m} / \mathrm{f}$ & $\mathrm{C}$ & $\mathrm{N}$ & $\mathrm{R}$ & $21 \mathrm{~m} / \mathrm{f}$ & $\begin{array}{l}\text { Bull and Duncan } \\
\text { (1993) }\end{array}$ \\
\hline $\begin{array}{l}\text { Strix } \\
\text { occidentalis }\end{array}$ & $\begin{array}{l}0.582 \mathrm{~m} \\
0.637 \mathrm{f}\end{array}$ & $\mathrm{D}$ & $29.0 \mathrm{~m} / \mathrm{f}$ & $87.4 \mathrm{~m} / \mathrm{f}$ & $\mathrm{C}$ & $\mathrm{T}$ & $\mathrm{R}$ & $11 \mathrm{~m} / \mathrm{f}$ & $\begin{array}{c}\text { Gutiérrez et al. (1985), } \\
\text { Miller and Meslow } \\
\text { (1985) }\end{array}$ \\
\hline $\begin{array}{l}\text { Speotyto } \\
\text { cunicularia }\end{array}$ & $0.150 \mathrm{~m} / \mathrm{f}$ & $S$ & $\ldots$ & $30.0 \mathrm{~m} / \mathrm{f}$ & $\mathrm{C}$ & G & M & $\ldots$ & Haug et al. (1993) \\
\hline $\begin{array}{l}\text { Aegolius } \\
\text { funereus }\end{array}$ & $\begin{array}{c}0.101 \mathrm{~m} \\
0.167 \mathrm{f}\end{array}$ & $\mathrm{D}$ & $\begin{array}{l}12.8 \mathrm{~m} \\
56.0 \mathrm{f}\end{array}$ & $\begin{array}{l}67.5 \mathrm{~m} \\
300.0 \mathrm{f}\end{array}$ & $\mathrm{C}$ & $\mathrm{N}$ & $\mathrm{R}$ & $\begin{array}{c}23 \mathrm{~m} / \mathrm{f} \\
13 \mathrm{~m} \\
37 \mathrm{f}\end{array}$ & $\begin{array}{l}\text { Wallin and Andersson } \\
\text { (1981), Löfgren et al. } \\
\text { (1986), Korpimäki } \\
\text { (1987), Korpimäki } \\
\text { and Lagerström } \\
\text { (1988) }\end{array}$ \\
\hline $\begin{array}{l}\text { Bubo } \\
\text { virginianus }\end{array}$ & $\begin{array}{l}1.154 \mathrm{~m} \\
1.555 \mathrm{f}\end{array}$ & $S$ & $\ldots$ & $1305.0 \mathrm{~m} / \mathrm{f}$ & $\mathrm{C}$ & $\mathrm{T}$ & $\mathrm{R}$ & $\begin{array}{l}111 \\
\mathrm{~m} / \mathrm{f}\end{array}$ & $\begin{array}{c}\text { Adamcik and Keith } \\
\text { (1978) }\end{array}$ \\
\hline $\begin{array}{l}\text { Picoides } \\
\text { borealis }\end{array}$ & $0.044 \mathrm{~m} / \mathrm{f}$ & $S$ & $\ldots$ & $90.0 \mathrm{~m} / \mathrm{f}$ & $\mathrm{O}$ & $\mathrm{T}$ & M & $\ldots$ & Jackson (1994) \\
\hline $\begin{array}{l}\text { Dryocopus } \\
\text { pileatus }\end{array}$ & $\begin{array}{l}0.31 \mathrm{~m} \\
0.27 \mathrm{f}\end{array}$ & S & $\ldots$ & $32.0 \mathrm{~m} / \mathrm{f}$ & $\mathrm{O}$ & $\mathrm{T}$ & $\mathrm{R}$ & $8 \mathrm{~m} / \mathrm{f}$ & $\begin{array}{l}\text { Bull and Jackson } \\
\text { (1995) }\end{array}$ \\
\hline Hirundo fulva & $0.020 \mathrm{~m} / \mathrm{f}$ & $S$ & $\ldots$ & $30.0 \mathrm{~m} / \mathrm{f}$ & $\mathrm{C}$ & G & M & $\ldots$ & West (1995) \\
\hline Hirundo rustica & $0.19 \mathrm{~m} / \mathrm{f}$ & $\mathrm{D}$ & $6.4 \mathrm{~m} / \mathrm{f}$ & $8.1 \mathrm{~m} / \mathrm{f}$ & $\mathrm{C}$ & G & $\mathrm{R}$ & $7 \mathrm{~m} / \mathrm{f}$ & $\begin{array}{c}\text { Allen and Nice } \\
\text { (1952), Shields (1982) }\end{array}$ \\
\hline $\begin{array}{l}\text { Iridoprocne } \\
\text { bicolor }\end{array}$ & $0.02 \mathrm{~m} / \mathrm{f}$ & $\mathrm{D}$ & $1.0 \mathrm{~m} / \mathrm{f}$ & $6.4 \mathrm{~m} / \mathrm{f}$ & $\mathrm{O}$ & $\mathrm{N}$ & M & $41 \mathrm{~m} / \mathrm{f}$ & Chapman (1955) \\
\hline
\end{tabular}




\begin{tabular}{|c|c|c|c|c|c|c|c|c|c|}
\hline Riparia riparia & $0.015 \mathrm{~m} / \mathrm{f}$ & $\mathrm{D}$ & $6.0 \mathrm{~m} / \mathrm{f}$ & $144.0 \mathrm{~m} / \mathrm{f}$ & $\mathrm{C}$ & $\mathrm{N}$ & M & $\begin{array}{c}3046 \\
\mathrm{~m} / \mathrm{f}\end{array}$ & Mead (1979) \\
\hline Progne subis & $0.049 \mathrm{~m} / \mathrm{f}$ & $\mathrm{D}$ & $40 \mathrm{~m} / \mathrm{f}$ & $336.0 \mathrm{~m} / \mathrm{f}$ & $\mathrm{O}$ & G & M & $46 \mathrm{~m} / \mathrm{f}$ & Allen and Nice (1952) \\
\hline $\begin{array}{l}\text { Delichon } \\
\text { urbica }\end{array}$ & $0.020 \mathrm{~m} / \mathrm{f}$ & $\mathrm{D}$ & $0.03 \mathrm{~m} / \mathrm{f}$ & $4.3 \mathrm{~m} / \mathrm{f}$ & $\mathrm{C}$ & $\mathrm{N}$ & M & $49 \mathrm{~m} / \mathrm{f}$ & Rheinwald (1975) \\
\hline $\begin{array}{l}\text { Aphelocoma } \\
\text { coerulescens }\end{array}$ & $0.080 \mathrm{~m} / \mathrm{f}$ & $\mathrm{D}$ & $\begin{array}{l}0.7 \mathrm{~m} \\
0.3 \mathrm{f}\end{array}$ & $\begin{array}{l}1.1 \mathrm{~m} \\
1.8 \mathrm{f}\end{array}$ & $\mathrm{H}$ & $\mathrm{N}$ & $\mathrm{R}$ & $\begin{array}{l}38 \mathrm{~m} \\
32 \mathrm{f}\end{array}$ & $\begin{array}{l}\text { Woolfenden and } \\
\text { Fitzpatrick (1978) }\end{array}$ \\
\hline $\begin{array}{l}\text { Malurus } \\
\text { splendens }\end{array}$ & $0.010 \mathrm{~m} / \mathrm{f}$ & $\mathrm{D}$ & $\begin{array}{l}0.20 \mathrm{~m} \\
0.20 \mathrm{f}\end{array}$ & $2.40 \mathrm{~m} / \mathrm{f}$ & $\mathrm{C}$ & G & $\mathrm{R}$ & $94 \mathrm{f}$ & $\begin{array}{l}\text { Russell and Rowley } \\
\qquad(1993)\end{array}$ \\
\hline $\begin{array}{l}\text { Gymnorhinus } \\
\text { cyanocephalus }\end{array}$ & $0.103 \mathrm{~m} / \mathrm{f}$ & $S$ & $\ldots$ & $640.0 \mathrm{~m} / \mathrm{f}$ & $\mathrm{O}$ & $\mathrm{N}$ & $\mathrm{R}$ & $\begin{array}{l}1064 \\
\mathrm{~m} / \mathrm{f}\end{array}$ & $\begin{array}{l}\text { Marzluff and Balda } \\
\text { (1989) }\end{array}$ \\
\hline $\begin{array}{l}\text { Sayornis } \\
\text { nigricans }\end{array}$ & $\begin{array}{l}0.02 \mathrm{~m} \\
0.018 \mathrm{f}\end{array}$ & $S$ & $\cdots$ & $\begin{array}{l}34.4 \mathrm{~m} \\
20.0 \mathrm{f}\end{array}$ & $\mathrm{C}$ & $\mathrm{T}$ & $\mathrm{R}$ & $\begin{array}{l}33 \mathrm{~m} \\
30 \mathrm{f}\end{array}$ & Wolf (1997) \\
\hline $\begin{array}{l}\text { Perisoreus } \\
\text { canadensis }\end{array}$ & $0.071 \mathrm{~m} / \mathrm{f}$ & $\mathrm{D}$ & $\begin{array}{l}0.0 \mathrm{~m} \\
2.8 \mathrm{f}\end{array}$ & $11.3 \mathrm{~m} / \mathrm{f}$ & $\mathrm{O}$ & $\mathrm{T}$ & $\mathrm{R}$ & $15 \mathrm{~m} / \mathrm{f}$ & Strickland (1991) \\
\hline Pica pica & $\begin{array}{l}0.189 \mathrm{~m} \\
0.166 \mathrm{f}\end{array}$ & $\mathrm{D}$ & $\begin{array}{c}0.35 \mathrm{~m} \\
0.5 \mathrm{f}\end{array}$ & $\begin{array}{l}1.3 \mathrm{~m} \\
0.8 \mathrm{f}\end{array}$ & $\mathrm{O}$ & $\mathrm{N}$ & $\mathrm{R}$ & $\ldots$ & Eden (1987) \\
\hline $\begin{array}{l}\text { Parus } \\
\text { atricapillus }\end{array}$ & $0.011 \mathrm{~m} / \mathrm{f}$ & $\mathrm{D}$ & $1.1 \mathrm{f}$ & $11.2 \mathrm{f}$ & $\mathrm{O}$ & $\mathrm{N}$ & $\mathrm{R}$ & $\begin{array}{l}58 \mathrm{~m} \\
45 \mathrm{f}\end{array}$ & $\begin{array}{l}\text { Weise and Meyer } \\
\text { (1979) }\end{array}$ \\
\hline Parus major & $\begin{array}{l}0.02 \mathrm{~m} \\
0.018 \mathrm{f}\end{array}$ & $\mathrm{D}$ & $\begin{array}{l}0.6 \mathrm{~m} \\
0.9 \mathrm{f}\end{array}$ & $\begin{array}{l}3.3 \mathrm{~m} \\
3.3 \mathrm{f}\end{array}$ & $\mathrm{O}$ & $\mathrm{T}$ & $\mathrm{R}$ & $\begin{array}{l}92 \mathrm{~m} \\
98 \mathrm{f}\end{array}$ & $\begin{array}{l}\text { Berndt and Sternberg } \\
\text { (1968), Greenwood et } \\
\text { al. (1979), Weise and } \\
\text { Meyer (1979), Nilsson } \\
\text { (1989) }\end{array}$ \\
\hline Parus palustris & $0.014 \mathrm{~m} / \mathrm{f}$ & $\mathrm{D}$ & $\begin{array}{l}1.1 \mathrm{~m} \\
2.6 \mathrm{f}\end{array}$ & $\begin{array}{l}4.6 \mathrm{~m} \\
7.3 \mathrm{f}\end{array}$ & $\mathrm{O}$ & $\mathrm{T}$ & $\mathrm{R}$ & $\begin{array}{c}65 \mathrm{~m} \\
53 \mathrm{f}\end{array}$ & Nilsson (1989) \\
\hline $\begin{array}{l}\text { Parus } \\
\text { caeruleus }\end{array}$ & $0.011 \mathrm{~m} / \mathrm{f}$ & $\mathrm{D}$ & $0.7 \mathrm{~m} / \mathrm{f}$ & $470.0 \mathrm{~m} / \mathrm{f}$ & $\mathrm{O}$ & $\mathrm{T}$ & $\mathrm{R}$ & $72 \mathrm{f}$ & $\begin{array}{l}\text { Berndt and Sternberg } \\
\text { (1968) }\end{array}$ \\
\hline Sitta europea & $0.022 \mathrm{~m} / \mathrm{f}$ & $\mathrm{D}$ & $\begin{array}{l}1.1 \mathrm{~m} \\
0.8 \mathrm{f}\end{array}$ & $\ldots$ & $\mathrm{O}$ & $\mathrm{T}$ & M & $\begin{array}{l}29 \mathrm{~m} \\
26 \mathrm{f}\end{array}$ & $\begin{array}{l}\text { Berndt and Sternberg } \\
\text { (1968), Mattysen and } \\
\text { Schmidt (1987) }\end{array}$ \\
\hline Vireo griseus & $0.011 \mathrm{~m} / \mathrm{f}$ & S & $\ldots$ & $20.0 \mathrm{~m} / \mathrm{f}$ & $\mathrm{C}$ & $\mathrm{T}$ & M & $\ldots$ & Hopp et al. (1995) \\
\hline $\begin{array}{l}\text { Lanius } \\
\text { ludovicianus }\end{array}$ & $0.047 \mathrm{~m} / \mathrm{f}$ & $\mathrm{D}$ & $7.3 \mathrm{~m} / \mathrm{f}$ & $79.7 \mathrm{~m} / \mathrm{f}$ & $\mathrm{O}$ & $\mathrm{T}$ & M & $69 \mathrm{~m} / \mathrm{f}$ & $\begin{array}{l}\text { Collister and De Smet } \\
\text { (1997) }\end{array}$ \\
\hline Turdus merula & $0.095 \mathrm{~m} / \mathrm{f}$ & $\mathrm{D}$ & $5.0 \mathrm{~m} / \mathrm{f}$ & $355.0 \mathrm{~m} / \mathrm{f}$ & $\mathrm{O}$ & $\mathrm{T}$ & $\mathrm{R}$ & $\begin{array}{l}74 \mathrm{~m} \\
50 \mathrm{f}\end{array}$ & $\begin{array}{c}\text { Allen and Nice } \\
\text { (1952), Greenwood } \\
\text { and Harvey (1977) }\end{array}$ \\
\hline Turdus merula & $0.095 \mathrm{~m} / \mathrm{f}$ & $\mathrm{D}$ & $4.0 \mathrm{~m} / \mathrm{f}$ & $355 \mathrm{~m} / \mathrm{f}$ & $\mathrm{O}$ & $\mathrm{T}$ & $\mathrm{R}$ & $\begin{array}{c}2204 \\
\mathrm{~m} / \mathrm{f}\end{array}$ & Paradis et al. (1998) \\
\hline $\begin{array}{l}\text { Toxostoma } \\
\text { curvirostre }\end{array}$ & $0.079 \mathrm{~m} / \mathrm{f}$ & $S$ & $\ldots$ & $30.0 \mathrm{~m} / \mathrm{f}$ & $\mathrm{C}$ & $\mathrm{T}$ & $\mathrm{R}$ & $\ldots$ & Tweit (1996) \\
\hline $\begin{array}{l}\text { Hylocichla } \\
\text { mustelina }\end{array}$ & $\begin{array}{l}0.044 \mathrm{~m} \\
0.050 \mathrm{f}\end{array}$ & S & $\ldots$ & $4.68 \mathrm{~m} / \mathrm{f}$ & $\mathrm{C}$ & $\mathrm{T}$ & M & $\begin{array}{l}680 \\
\mathrm{~m} / \mathrm{f}\end{array}$ & Anders et al. (1998) \\
\hline
\end{tabular}




\begin{tabular}{|c|c|c|c|c|c|c|c|c|c|}
\hline $\begin{array}{l}\text { Acrocephalus } \\
\text { scirpaceus }\end{array}$ & $0.012 \mathrm{~m} / \mathrm{f}$ & $\mathrm{D}$ & $51 \mathrm{~m} / \mathrm{f}$ & $271 \mathrm{~m} / \mathrm{f}$ & $\mathrm{C}$ & $\mathrm{N}$ & M & $78 \mathrm{~m} / \mathrm{f}$ & Paradis et al. (1998) \\
\hline Motacilla alba & $0.24 \mathrm{~m} / \mathrm{f}$ & S & $\ldots$ & $100.0 \mathrm{~m} / \mathrm{f}$ & $\mathrm{C}$ & $\mathrm{N}$ & M & $\ldots$ & Badyaev et al. (1996) \\
\hline $\begin{array}{l}\text { Seiurus } \\
\text { motacilla }\end{array}$ & $\begin{array}{l}0.020 \mathrm{~m} \\
0.021 \mathrm{f}\end{array}$ & $S$ & $\ldots$ & $4.0 \mathrm{~m} / \mathrm{f}$ & $\mathrm{C}$ & $\mathrm{T}$ & M & $\ldots$ & Robinson (1995) \\
\hline $\begin{array}{l}\text { Passerculus } \\
\text { sandwichensis }\end{array}$ & $0.019 \mathrm{~m} / \mathrm{f}$ & $\mathrm{D}$ & $\begin{array}{c}0.248 \mathrm{f} \\
0.202 \mathrm{~m}\end{array}$ & $\begin{array}{l}1.4 \mathrm{f} \\
1.6 \mathrm{~m}\end{array}$ & $\mathrm{H}$ & $\mathrm{N}$ & M & $\begin{array}{l}65 \mathrm{~m} \\
76 \mathrm{f}\end{array}$ & $\begin{array}{l}\text { Wheelwright and } \\
\text { Mauck (1998) }\end{array}$ \\
\hline $\begin{array}{l}\text { Melospiza } \\
\text { melodia }\end{array}$ & $0.021 \mathrm{~m} / \mathrm{f}$ & $\mathrm{D}$ & $\begin{array}{l}0.20 \mathrm{~m} \\
0.20 \mathrm{f}\end{array}$ & $\begin{array}{l}13.2 \mathrm{~m} \\
1.3 \mathrm{f}\end{array}$ & $\mathrm{H}$ & $\mathrm{T}$ & $\mathrm{R}$ & $\begin{array}{l}36 \mathrm{~m} / \mathrm{f} \\
34 \mathrm{~m} / \mathrm{f}\end{array}$ & $\begin{array}{l}\text { Nice (1937), Johnston } \\
\text { (1956), Halliburton } \\
\text { and Mewaldt (1976), } \\
\text { Arcese (1989) }\end{array}$ \\
\hline $\begin{array}{l}\text { Zonotrichia } \\
\text { leucophrys }\end{array}$ & $0.294 \mathrm{~m} / \mathrm{f}$ & $\mathrm{D}$ & $\begin{array}{l}0.3 \mathrm{~m} \\
0.4 \mathrm{f}\end{array}$ & $2.6 \mathrm{~m} / \mathrm{f}$ & $\mathrm{O}$ & $\mathrm{T}$ & M & $\begin{array}{l}138 \mathrm{~m} \\
173 \mathrm{f}\end{array}$ & $\begin{array}{l}\text { Baker and Mewaldt } \\
\qquad(1978)\end{array}$ \\
\hline $\begin{array}{l}\text { Passerina } \\
\text { cyanea }\end{array}$ & $0.108 \mathrm{~m} / \mathrm{f}$ & $S$ & $\ldots$ & $470.0 \mathrm{~m} / \mathrm{f}$ & $\mathrm{O}$ & $\mathrm{N}$ & M & $\ldots$ & Payne (1991) \\
\hline $\begin{array}{l}\text { Carduelis } \\
\text { chloris }\end{array}$ & $0.03 \mathrm{~m} / \mathrm{f}$ & $\mathrm{D}$ & $\begin{array}{l}7.0 \mathrm{~m} \\
3.0 \mathrm{f}\end{array}$ & $\begin{array}{l}150.0 \mathrm{~m} \\
37.5 \mathrm{f}\end{array}$ & $\mathrm{H}$ & $\mathrm{T}$ & $\mathrm{R}$ & $\begin{array}{c}15 \mathrm{~m} \\
11 \mathrm{f}\end{array}$ & $\begin{array}{l}\text { Greenwood and } \\
\text { Harvey (1977) }\end{array}$ \\
\hline $\begin{array}{l}\text { Ficedula } \\
\text { hypoleuca }\end{array}$ & $0.015 \mathrm{~m} / \mathrm{f}$ & $\mathrm{D}$ & $0.9 \mathrm{~m} / \mathrm{f}$ & $75.0 \mathrm{~m} / \mathrm{f}$ & $\mathrm{O}$ & $\mathrm{T}$ & M & $\begin{array}{l}473 \\
\mathrm{~m} / \mathrm{f}\end{array}$ & $\begin{array}{l}\text { Berndt and Sternberg } \\
\text { (1968), Pärt (1990) }\end{array}$ \\
\hline $\begin{array}{l}\text { Quiscalus } \\
\text { major }\end{array}$ & $\begin{array}{l}0.21 \mathrm{~m} \\
0.12 \mathrm{f}\end{array}$ & $S$ & $\cdots$ & $\begin{array}{l}35.0 \mathrm{~m} \\
7.0 \mathrm{f}\end{array}$ & $\mathrm{O}$ & G & $\mathrm{R}$ & $\ldots$ & Post et al. (1996) \\
\hline Molothrus ater & $\begin{array}{l}0.05 \mathrm{~m} \\
0.04 \mathrm{f}\end{array}$ & S & $\cdots$ & $40.0 \mathrm{~m} / \mathrm{f}$ & $\mathrm{O}$ & $\mathrm{N}$ & M & $15 \mathrm{~m} / \mathrm{f}$ & Lowther (1993) \\
\hline
\end{tabular}

Table A2. Mammals

\begin{tabular}{|c|c|c|c|c|c|c|c|c|}
\hline Species & $\begin{array}{c}\text { Body } \\
\text { mass } \\
(\text { kg) }\end{array}$ & $\begin{array}{l}\text { Obs } \\
\text { type }\end{array}$ & $\begin{array}{c}\text { Natal } \\
\text { dispersal } \\
\text { median } \\
\text { distance }(\mathbf{k m})\end{array}$ & $\begin{array}{c}\text { Natal } \\
\text { dispersal } \\
\text { maximum } \\
\text { distance }(\mathbf{k m})\end{array}$ & 1 & 2 & $n$ & Source \\
\hline $\begin{array}{l}\text { Didelphis } \\
\text { virginianus }\end{array}$ & $\begin{array}{c}2.839 \mathrm{~m} \\
1.99 \mathrm{f}\end{array}$ & $S$ & $\ldots$ & $\begin{array}{l}4.3 \mathrm{~m} \\
5.152 \mathrm{f}\end{array}$ & $\mathrm{O}$ & $\mathrm{T}$ & 8 & VanDruff (1969) \\
\hline $\begin{array}{l}\text { Phascogale } \\
\text { tapotafa }\end{array}$ & $\begin{array}{c}0.199 \mathrm{~m} \\
0.145 \mathrm{f}\end{array}$ & $S$ & $\ldots$ & $6.8 \mathrm{~m}$ & $\mathrm{C}$ & $\mathrm{T}$ & $\cdots$ & $\begin{array}{l}\text { Soderquist and Lill } \\
\text { (1995) }\end{array}$ \\
\hline $\begin{array}{l}\text { Trichosurus } \\
\text { vulpecula }\end{array}$ & $2.93 \mathrm{~m} / \mathrm{f}$ & $\mathrm{D}$ & $5.4 \mathrm{~m}$ & $12.8 \mathrm{~m}$ & $\mathrm{C}$ & $\mathrm{T}$ & $13 \mathrm{~m}$ & Cowan et al. (1996) \\
\hline Sorex araneus & $0.004 \mathrm{~m} / \mathrm{f}$ & $S$ & ... & $0.869 \mathrm{~m} / \mathrm{f}$ & $\mathrm{C}$ & $\mathrm{N}$ & $\begin{array}{l}29 \mathrm{~m} \\
21 \mathrm{f}\end{array}$ & $\begin{array}{l}\text { Hanski et al. (1991), } \\
\text { Peltonen and Hanski } \\
\text { (1991) }\end{array}$ \\
\hline $\begin{array}{l}\text { Scapanus } \\
\text { townsendii }\end{array}$ & $0.148 \mathrm{~m} / \mathrm{f}$ & $S$ & $\cdots$ & $\begin{array}{l}0.722 \mathrm{~m} \\
0.856 \mathrm{f}\end{array}$ & $\mathrm{O}$ & G & $\begin{array}{l}44 \\
\mathrm{~m} / \mathrm{f}\end{array}$ & Carraway et al. (1993) \\
\hline $\begin{array}{l}\text { Ursus } \\
\text { americanus }\end{array}$ & $\begin{array}{c}130.0 \mathrm{~m} \\
78.9 \mathrm{f}\end{array}$ & $S$ & $\cdots$ & $\begin{array}{c}225.0 \mathrm{~m} \\
28.8 \mathrm{f}\end{array}$ & $\mathrm{O}$ & $\mathrm{T}$ & $\begin{array}{l}19 \mathrm{~m} \\
15 \mathrm{f}\end{array}$ & Rogers (1987) \\
\hline
\end{tabular}




\begin{tabular}{|c|c|c|c|c|c|c|c|c|}
\hline Ursus arctos & $331.0 \mathrm{~m} / \mathrm{f}$ & $S$ & $\ldots$ & $\begin{array}{l}134.0 \mathrm{~m} \\
82.0 \mathrm{f}\end{array}$ & $\mathrm{O}$ & $\mathrm{T}$ & $\begin{array}{l}35 \mathrm{~m} \\
26 \mathrm{f}\end{array}$ & $\begin{array}{c}\text { Glenn and Miller } \\
\text { (1980) }\end{array}$ \\
\hline Ursus arctos & $331.0 \mathrm{~m} / \mathrm{f}$ & $\mathrm{D}$ & $\begin{array}{l}5.5 \mathrm{~m} \\
9.5 \mathrm{f}\end{array}$ & $\ldots$ & $\mathrm{O}$ & $\mathrm{T}$ & $\begin{array}{c}222 \\
\mathrm{~m} \\
343 \mathrm{f}\end{array}$ & Pearson (1972) \\
\hline Procyon lotor & $\begin{array}{l}8.1 \mathrm{~m} \\
7.5 \mathrm{f}\end{array}$ & $S$ & $\ldots$ & $265.5 \mathrm{~m} / \mathrm{f}$ & $\mathrm{O}$ & $\mathrm{T}$ & $\begin{array}{c}34 \\
\mathrm{~m} / \mathrm{f}\end{array}$ & $\begin{array}{l}\text { Priewert (1951), } \\
\text { Lynch (1967) }\end{array}$ \\
\hline $\begin{array}{l}\text { Martes } \\
\text { americana }\end{array}$ & $1.04 \mathrm{~m} / \mathrm{f}$ & $S$ & $\ldots$ & $61.0 \mathrm{~m} / \mathrm{f}$ & $\mathrm{C}$ & $\mathrm{T}$ & $\begin{array}{l}15 \\
\mathrm{~m} / \mathrm{f}\end{array}$ & Lofroth (1993) \\
\hline $\begin{array}{l}\text { Martes } \\
\text { pennanti }\end{array}$ & $\begin{array}{l}3.70 \mathrm{~m} \\
2.10 \mathrm{f}\end{array}$ & $S$ & $\ldots$ & $\begin{array}{l}23.0 \mathrm{~m} \\
22.6 \mathrm{f}\end{array}$ & $\mathrm{C}$ & $\mathrm{T}$ & $\begin{array}{l}35 \\
\mathrm{~m} / \mathrm{f}\end{array}$ & Arthur et al. (1993) \\
\hline $\begin{array}{l}\text { Mustela } \\
\text { erminea }\end{array}$ & $\begin{array}{l}0.080 \mathrm{~m} \\
0.054 \mathrm{f}\end{array}$ & $S$ & $\ldots$ & $\begin{array}{l}5.6 \mathrm{~m} \\
1.0 \mathrm{f}\end{array}$ & $\mathrm{C}$ & $\mathrm{T}$ & $\begin{array}{l}36 \mathrm{~m} \\
29 \mathrm{f}\end{array}$ & Erlinge (1977) \\
\hline Mustela vison & $\begin{array}{l}1.225 \mathrm{~m} \\
1.112 \mathrm{f}\end{array}$ & $S$ & $\ldots$ & $\begin{array}{l}45.1 \mathrm{~m} \\
45.0 \mathrm{f}\end{array}$ & $\mathrm{C}$ & $\mathrm{T}$ & $\begin{array}{l}6 \mathrm{~m} \\
2 \mathrm{f}\end{array}$ & Mitchell (1961) \\
\hline $\begin{array}{l}\text { Lutra } \\
\text { canadensis }\end{array}$ & $9.07 \mathrm{~m}$ & $S$ & $\ldots$ & $42.0 \mathrm{~m}$ & $\mathrm{C}$ & $\mathrm{T}$ & $\begin{array}{l}39 \\
\mathrm{~m} / \mathrm{f}\end{array}$ & $\begin{array}{c}\text { Melquist and } \\
\text { Hornocker (1983) }\end{array}$ \\
\hline Gulo gulo & $14.4 \mathrm{~m} / \mathrm{f}$ & $S$ & $\ldots$ & $300 \mathrm{~m} / \mathrm{f}$ & $\mathrm{C}$ & $\mathrm{T}$ & $\ldots$ & $\begin{array}{l}\text { Pasitschniak-Arts and } \\
\text { Lariviere (1995) }\end{array}$ \\
\hline Taxidea taxus & $\begin{array}{l}7.80 \mathrm{~m} \\
6.15 \mathrm{f}\end{array}$ & $S$ & $\cdots$ & $\begin{array}{l}110.0 \mathrm{~m} \\
52.0 \mathrm{f}\end{array}$ & $\mathrm{C}$ & $\mathrm{T}$ & $\begin{array}{c}1 \mathrm{~m} \\
1 \mathrm{f}\end{array}$ & Lindzey (1978) \\
\hline Meles meles & $\begin{array}{l}11.6 \mathrm{~m} \\
10.1 \mathrm{f}\end{array}$ & $S$ & $\cdots$ & $\begin{array}{l}8.3 \mathrm{~m} \\
7.8 \mathrm{f}\end{array}$ & $\mathrm{O}$ & G & $\ldots$ & Cheesman et al. (1988) \\
\hline $\begin{array}{l}\text { Mephitis } \\
\text { mephitis }\end{array}$ & $\begin{array}{l}3.176 \mathrm{~m} \\
2.642 \mathrm{f}\end{array}$ & $S$ & $\cdots$ & $\begin{array}{l}10.1 \mathrm{~m} \\
21.7 \mathrm{f}\end{array}$ & $\mathrm{O}$ & $\mathrm{T}$ & $\begin{array}{l}1 \mathrm{~m} \\
4 \mathrm{f}\end{array}$ & Bjorge et al. (1981) \\
\hline $\begin{array}{l}\text { Helogale } \\
\text { parvula }\end{array}$ & $0.350 \mathrm{~m} / \mathrm{f}$ & $\mathrm{D}$ & $\begin{array}{c}0.25 \mathrm{~m} \\
0.75 \mathrm{f}\end{array}$ & $\cdots$ & $\mathrm{C}$ & $\mathrm{T}$ & $\begin{array}{l}44 \mathrm{~m} \\
22 \mathrm{f}\end{array}$ & Rood (1987) \\
\hline Canis latrans & $14.06 \mathrm{~m} / \mathrm{f}$ & $S$ & $\ldots$ & $\begin{array}{l}176.0 \mathrm{~m} \\
232.2 \mathrm{f}\end{array}$ & $\mathrm{C}$ & $\mathrm{N}$ & 125 & $\begin{array}{c}\text { Andrews and Boggess } \\
(1978)\end{array}$ \\
\hline Canis latrans & $14.06 \mathrm{~m} / \mathrm{f}$ & $\mathrm{D}$ & $\begin{array}{l}16.6 \mathrm{~m} \\
42.2 \mathrm{f}\end{array}$ & $\cdots$ & $\mathrm{C}$ & $\mathrm{N}$ & $7 \mathrm{~m}$ & Bowen (1982) \\
\hline Canis lupus & $\begin{array}{l}42.54 \mathrm{~m} \\
40.22 \mathrm{f}\end{array}$ & $S$ & $\cdots$ & $\begin{array}{l}432.0 \mathrm{~m} \\
79 \mathrm{f}\end{array}$ & $\mathrm{C}$ & $\mathrm{T}$ & $\begin{array}{l}5 \mathrm{~m} \\
2 \mathrm{f}\end{array}$ & $\begin{array}{l}\text { Berg and Kuehn } \\
\text { (1982), Mech (1987) }\end{array}$ \\
\hline Canis lupus & $\begin{array}{l}42.54 \mathrm{~m} \\
40.22 \mathrm{f}\end{array}$ & $\mathrm{D}$ & $\begin{array}{l}125.0 \mathrm{~m} \\
125.0 \mathrm{f}\end{array}$ & $\cdots$ & $\mathrm{C}$ & $\mathrm{T}$ & $\begin{array}{l}9 \mathrm{~m} \\
5 \mathrm{f}\end{array}$ & Ballard et al. (1987) \\
\hline Canis lupus & $\begin{array}{l}42.54 \mathrm{~m} \\
40.22 \mathrm{f}\end{array}$ & $\mathrm{D}$ & $\begin{array}{l}225.0 \mathrm{~m} \\
75.0 \mathrm{f}\end{array}$ & $\cdots$ & $\mathrm{C}$ & $\mathrm{T}$ & $\begin{array}{l}40 \mathrm{~m} \\
29 \mathrm{f}\end{array}$ & Gese and Mech (1991) \\
\hline Vulpes vulpes & $5.20 \mathrm{~m} / \mathrm{f}$ & S & $\ldots$ & $\begin{array}{l}394.5 \mathrm{~m} \\
302.0 \mathrm{f}\end{array}$ & $\mathrm{C}$ & $\mathrm{T}$ & $\begin{array}{l}1 \mathrm{~m} \\
72 \mathrm{f}\end{array}$ & $\begin{array}{l}\text { Ables (1965), Allen } \\
\text { and Sargent (1993) }\end{array}$ \\
\hline Vulpes vulpes & $5.20 \mathrm{~m} / \mathrm{f}$ & $\mathrm{D}$ & $\begin{array}{l}8.6 \mathrm{~m} \\
4.9 \mathrm{f}\end{array}$ & $\cdots$ & $\mathrm{C}$ & $\mathrm{T}$ & $\begin{array}{l}31 \mathrm{~m} \\
31 \mathrm{f}\end{array}$ & Jensen (1973) \\
\hline
\end{tabular}




\begin{tabular}{|c|c|c|c|c|c|c|c|c|}
\hline Vulpes vulpes & $5.20 \mathrm{~m} / \mathrm{f}$ & $\mathrm{D}$ & $\begin{array}{c}24.2 \mathrm{~m} \\
8.1 \mathrm{f}\end{array}$ & ... & $\mathrm{C}$ & $\mathrm{T}$ & $\begin{array}{c}298 \\
\mathrm{~m} \\
207 \mathrm{f}\end{array}$ & Storm et al. (1976) \\
\hline Vulpes vulpes & $5.20 \mathrm{~m} / \mathrm{f}$ & $\mathrm{D}$ & $\begin{array}{l}8.1 \mathrm{~m} \\
8.1 \mathrm{f}\end{array}$ & $\ldots$ & $\mathrm{C}$ & $\mathrm{T}$ & $\begin{array}{c}171 \\
\mathrm{~m} \\
124 \mathrm{f}\end{array}$ & Phillips et al. (1972) \\
\hline Vulpes vulpes & $5.20 \mathrm{~m} / \mathrm{f}$ & $\mathrm{D}$ & $\begin{array}{l}12.0 \mathrm{~m} \\
12.4 \mathrm{f}\end{array}$ & $\cdots$ & $\mathrm{C}$ & $\mathrm{T}$ & $\begin{array}{c}16 \mathrm{~m} \\
4 \mathrm{f}\end{array}$ & Zimen (1984) \\
\hline $\begin{array}{l}\text { Urocyon } \\
\text { cinereoargente } \\
\text { us }\end{array}$ & $\begin{array}{l}4.1 \mathrm{~m} \\
3.9 \mathrm{f}\end{array}$ & $S$ & $\ldots$ & $83.68 \mathrm{f}$ & $\mathrm{C}$ & $\mathrm{T}$ & $\ldots$ & Sullivan (1956) \\
\hline Felis concolor & $\begin{array}{l}61.6 \mathrm{~m} \\
44.5 \mathrm{f}\end{array}$ & $S$ & $\cdots$ & $\begin{array}{l}274.0 \mathrm{~m} \\
155.0 \mathrm{f}\end{array}$ & $\mathrm{C}$ & $\mathrm{T}$ & $\begin{array}{l}33 \mathrm{~m} \\
13 \mathrm{f}\end{array}$ & $\begin{array}{c}\text { Logan et al. (1986), } \\
\text { Ross and Jalotsky } \\
\text { (1992) }\end{array}$ \\
\hline Lynx lynx & $10.149 \mathrm{f}$ & S & $\ldots$ & $9.7 \mathrm{f}$ & $\mathrm{C}$ & $\mathrm{T}$ & 1 & Saunders (1963) \\
\hline Lynx rufus & $8.2 \mathrm{f}$ & $S$ & $\ldots$ & $56.0 \mathrm{f}$ & $\mathrm{C}$ & $\mathrm{T}$ & 10 & $\begin{array}{c}\text { Robinson and Grant } \\
\text { (1958) }\end{array}$ \\
\hline Lynx rufus & $9.6 \mathrm{~m}$ & $S$ & $\ldots$ & $182 \mathrm{~m}$ & $\mathrm{C}$ & $\mathrm{T}$ & $\ldots$ & $\begin{array}{l}\text { Lariviere and Walton } \\
\text { (1997) }\end{array}$ \\
\hline $\begin{array}{l}\text { Castor } \\
\text { canadensis }\end{array}$ & $24.3 \mathrm{f}$ & $S$ & $2.1 \mathrm{~m} / \mathrm{f}$ & $40.6 \mathrm{~m} / \mathrm{f}$ & $\mathrm{H}$ & $\mathrm{T}$ & $\begin{array}{l}19 \\
\mathrm{~m} / \mathrm{f}\end{array}$ & Leege (1963) \\
\hline $\begin{array}{l}\text { Marmota } \\
\text { flaviventris }\end{array}$ & $5.448 \mathrm{~m}$ & $S$ & $\ldots$ & $1.4 \mathrm{~m}$ & $\mathrm{H}$ & G & 2 & $\begin{array}{c}\text { Armitage (1974), } \\
\text { Armitage and } \\
\text { Downhower (1974) }\end{array}$ \\
\hline $\begin{array}{l}\text { Marmota } \\
\text { monax }\end{array}$ & $\begin{array}{l}3.511 \mathrm{~m} \\
3.486 \mathrm{f}\end{array}$ & $S$ & $\cdots$ & $\begin{array}{l}0.685 \mathrm{~m} \\
0.768 \mathrm{f}\end{array}$ & $\mathrm{H}$ & $\mathrm{N}$ & $\begin{array}{l}46 \\
\mathrm{~m} / \mathrm{f}\end{array}$ & Swihart (1992) \\
\hline $\begin{array}{l}\text { Spermophilus } \\
\text { richardsonii }\end{array}$ & $0.405 \mathrm{~m} / \mathrm{f}$ & $\mathrm{D}$ & $\begin{array}{l}0.05 \mathrm{~m} \\
0.05 \mathrm{f}\end{array}$ & $\begin{array}{l}0.975 \mathrm{~m} \\
0.525 \mathrm{f}\end{array}$ & $\mathrm{H}$ & G & $\begin{array}{l}26 \mathrm{~m} \\
26 \mathrm{f}\end{array}$ & $\begin{array}{l}\text { Mitchener and } \\
\text { Mitchener (1977) }\end{array}$ \\
\hline $\begin{array}{l}\text { Spermophilus } \\
\text { beecheyi }\end{array}$ & $0.475 \mathrm{~m} / \mathrm{f}$ & $S$ & $\ldots$ & $\begin{array}{l}1.44 \mathrm{~m} \\
1.312 \mathrm{f}\end{array}$ & $\mathrm{H}$ & G & $\begin{array}{l}56 \mathrm{~m} \\
25 \mathrm{f}\end{array}$ & $\begin{array}{c}\text { Evans and Holdenried } \\
\text { (1943) }\end{array}$ \\
\hline $\begin{array}{l}\text { Spermophilus } \\
\text { beldingi }\end{array}$ & $0.400 \mathrm{~m} / \mathrm{f}$ & $S$ & $\ldots$ & $0.328 \mathrm{~m} / \mathrm{f}$ & $\mathrm{H}$ & G & $\begin{array}{c}25 \mathrm{~m} \\
2 \mathrm{f}\end{array}$ & Holekamp (1984) \\
\hline $\begin{array}{l}\text { Spermophilus } \\
\text { leucopus }\end{array}$ & $0.192 \mathrm{~m} / \mathrm{f}$ & $S$ & $\ldots$ & $\begin{array}{l}0.515 \mathrm{~m} \\
0.321 \mathrm{f}\end{array}$ & $\mathrm{H}$ & $\mathrm{N}$ & $\begin{array}{l}65 \mathrm{~m} \\
83 \mathrm{f}\end{array}$ & $\begin{array}{l}\text { Allred and Beck } \\
\text { (1963) }\end{array}$ \\
\hline $\begin{array}{l}\text { Spermophilus } \\
\text { tridecemliniatu } \\
s\end{array}$ & $0.140 \mathrm{~m}$ & $\mathrm{~S}$ & $\ldots$ & $0.239 \mathrm{~m}$ & $\mathrm{H}$ & $\mathrm{T}$ & $\begin{array}{l}46 \mathrm{~m} \\
45 \mathrm{f}\end{array}$ & Rongstad (1965) \\
\hline Sciurus niger & $0.790 \mathrm{~m} / \mathrm{f}$ & S & $\ldots$ & $3.37 \mathrm{~m} / \mathrm{f}$ & $\mathrm{H}$ & $\mathrm{T}$ & 2 & Fitch (1958) \\
\hline $\begin{array}{l}\text { Tamiasciurus } \\
\text { hudsonicus }\end{array}$ & $\begin{array}{l}0.204 \mathrm{~m} \\
0.199 \mathrm{f}\end{array}$ & $\mathrm{D}$ & $\begin{array}{c}0.485 \mathrm{~m} \\
0.24 \mathrm{f}\end{array}$ & $\begin{array}{l}0.60 \mathrm{~m} \\
0.60 \mathrm{f}\end{array}$ & $\mathrm{H}$ & $\mathrm{T}$ & $8 \mathrm{~m} / \mathrm{f}$ & Sun (1997) \\
\hline $\begin{array}{l}\text { Thomomys } \\
\text { bottae }\end{array}$ & $0.150 \mathrm{~m} / \mathrm{f}$ & S & $\ldots$ & $0.30 \mathrm{~m} / \mathrm{f}$ & $\mathrm{C}$ & $\mathrm{T}$ & $\begin{array}{l}2 \mathrm{~m} \\
1 \mathrm{f}\end{array}$ & $\begin{array}{l}\text { Daly and Patton } \\
\text { (1990) }\end{array}$ \\
\hline
\end{tabular}




\begin{tabular}{|c|c|c|c|c|c|c|c|c|}
\hline $\begin{array}{l}\text { Perognathus } \\
\text { formosa }\end{array}$ & $0.023 \mathrm{~m}$ & $\mathrm{~S}$ & $\ldots$ & 0.853 & $\mathrm{H}$ & $\mathrm{T}$ & $\begin{array}{c}28 \mathrm{~m} \\
18 \mathrm{f}\end{array}$ & $\begin{array}{l}\text { Allred and Beck } \\
\qquad(1963)\end{array}$ \\
\hline $\begin{array}{l}\text { Dipodomys } \\
\text { merriami }\end{array}$ & $\begin{array}{l}0.044 \mathrm{~m} \\
0.0426 \mathrm{f}\end{array}$ & $\mathrm{D}$ & $\begin{array}{l}0.13 \mathrm{~m} \\
0.03 \mathrm{f}\end{array}$ & $\begin{array}{l}0.25 \mathrm{~m} \\
0.158 \mathrm{f}\end{array}$ & $\mathrm{H}$ & $\mathrm{T}$ & $\begin{array}{l}13 \mathrm{~m} \\
13 \mathrm{f}\end{array}$ & Jones (1989) \\
\hline $\begin{array}{l}\text { Dipodomys } \\
\text { microps }\end{array}$ & $0.065 \mathrm{~m} / \mathrm{f}$ & $S$ & $\ldots$ & $\begin{array}{l}0.411 \mathrm{~m} \\
0.434 \mathrm{f}\end{array}$ & $\mathrm{H}$ & $\mathrm{T}$ & $\begin{array}{c}159 \\
\mathrm{~m} \\
172 \mathrm{f}\end{array}$ & $\begin{array}{l}\text { Allred and Beck } \\
\text { (1963) }\end{array}$ \\
\hline $\begin{array}{l}\text { Dipodomys } \\
\text { spectabilis }\end{array}$ & $0.115 \mathrm{~m} / \mathrm{f}$ & $\mathrm{S}$ & $\ldots$ & $\begin{array}{l}0.9 \mathrm{~m} \\
2.0 \mathrm{f}\end{array}$ & $\mathrm{H}$ & $\mathrm{T}$ & $\ldots$ & Jones (1987) \\
\hline $\begin{array}{l}\text { Dipodomys } \\
\text { spectabilis }\end{array}$ & $0.115 \mathrm{~m} / \mathrm{f}$ & $\mathrm{D}$ & $\begin{array}{c}0.03 \mathrm{~m} \\
0.03 \mathrm{f}\end{array}$ & $\cdots$ & $\mathrm{H}$ & $\mathrm{T}$ & $\begin{array}{l}82 \mathrm{~m} \\
84 \mathrm{f}\end{array}$ & $\begin{array}{l}\text { Waser and Elliott } \\
\text { (1991) }\end{array}$ \\
\hline $\begin{array}{l}\text { Dipodomys } \\
\text { spectabilis }\end{array}$ & $0.115 \mathrm{~m} / \mathrm{f}$ & $\mathrm{D}$ & $\begin{array}{l}0.03 \mathrm{~m} \\
0.03 \mathrm{f}\end{array}$ & $\cdots$ & $\mathrm{H}$ & $\mathrm{T}$ & $\begin{array}{l}22 \mathrm{~m} \\
18 \mathrm{f}\end{array}$ & Jones (1987) \\
\hline $\begin{array}{l}\text { Dipodomys } \\
\text { stephensi }\end{array}$ & $0.064 \mathrm{~m} / \mathrm{f}$ & $\mathrm{D}$ & $\begin{array}{c}0.087 \mathrm{~m} \\
0.045 \mathrm{f}\end{array}$ & $\cdots$ & $\mathrm{H}$ & $\mathrm{T}$ & $\begin{array}{l}13 \mathrm{~m} \\
18 \mathrm{f}\end{array}$ & Price et al. (1994) \\
\hline $\begin{array}{l}\text { Neotoma } \\
\text { cinerea }\end{array}$ & $\begin{array}{l}0.42 \mathrm{~m} \\
0.30 \mathrm{f}\end{array}$ & S & $\cdots$ & $2.2 \mathrm{~m}$ & $\mathrm{H}$ & $\mathrm{T}$ & $\ldots$ & Smith (1997) \\
\hline $\begin{array}{l}\text { Clethrionomys } \\
\text { glareolus }\end{array}$ & $0.023 \mathrm{~m} / \mathrm{f}$ & S & $\ldots$ & $0.40 \mathrm{~m} / \mathrm{f}$ & $\mathrm{H}$ & $\mathrm{T}$ & $\begin{array}{l}58 \\
\mathrm{~m} / \mathrm{f}\end{array}$ & $\begin{array}{c}\text { Dickman and } \\
\text { Doncaster (1989) }\end{array}$ \\
\hline $\begin{array}{l}\text { Onychomys } \\
\text { torridus }\end{array}$ & $26.8 \mathrm{~m} / \mathrm{f}$ & S & $\ldots$ & $\begin{array}{c}0.329 \mathrm{~m} \\
0.325 \mathrm{f}\end{array}$ & $\mathrm{H}$ & $\mathrm{T}$ & $1 \mathrm{~m}$ & $\begin{array}{l}\text { Allred and Beck } \\
\text { (1963) }\end{array}$ \\
\hline $\begin{array}{l}\text { Microtus } \\
\text { agrestis }\end{array}$ & $0.023 \mathrm{~m} / \mathrm{f}$ & $\mathrm{D}$ & $\begin{array}{c}0.03 \mathrm{~m} \\
0.03 \mathrm{f}\end{array}$ & $\begin{array}{l}0.159 \mathrm{~m} \\
0.193 \mathrm{f}\end{array}$ & $\mathrm{H}$ & $\mathrm{T}$ & $\begin{array}{l}39 \mathrm{~m} \\
19 \mathrm{f}\end{array}$ & Sandell et al. (1990) \\
\hline $\begin{array}{l}\text { Microtus } \\
\text { arvalis }\end{array}$ & $0.022 \mathrm{f}$ & $\mathrm{D}$ & $0.03 \mathrm{f}$ & $0.2 \mathrm{f}$ & $\mathrm{H}$ & $\mathrm{N}$ & $31 \mathrm{f}$ & $\begin{array}{l}\text { Boyce and Boyce } \\
\text { (1988) }\end{array}$ \\
\hline $\begin{array}{l}\text { Microtus } \\
\text { ochrogaster }\end{array}$ & $\begin{array}{c}0.028 \mathrm{~m} \\
0.033 \mathrm{f}\end{array}$ & $S$ & $\ldots$ & $\begin{array}{c}0.136 \mathrm{~m} \\
0.127 \mathrm{f}\end{array}$ & $\mathrm{H}$ & $\mathrm{T}$ & $\begin{array}{l}79 \mathrm{~m} \\
78 \mathrm{f}\end{array}$ & McGuire et al. (1993) \\
\hline $\begin{array}{l}\text { Microtus } \\
\text { oeconomus }\end{array}$ & $0.032 \mathrm{~m} / \mathrm{f}$ & $\mathrm{D}$ & $0.75 \mathrm{~m}$ & $1.0 \mathrm{~m}$ & $\mathrm{H}$ & $\mathrm{T}$ & $5 \mathrm{~m}$ & Steen (1994) \\
\hline $\begin{array}{l}\text { Microtus } \\
\text { pennsylvanicus }\end{array}$ & $0.040 \mathrm{~m} / \mathrm{f}$ & $S$ & $\ldots$ & $0.245 \mathrm{~m} / \mathrm{f}$ & $\mathrm{H}$ & $\mathrm{T}$ & 1 & Mihok et al. (1988) \\
\hline $\begin{array}{l}\text { Microtus } \\
\text { townsendi }\end{array}$ & $0.032 \mathrm{~m} / \mathrm{f}$ & $\mathrm{D}$ & $\begin{array}{c}0.008 \mathrm{~m} \\
0.003 \mathrm{f}\end{array}$ & $\begin{array}{l}0.068 \mathrm{~m} \\
0.054 \mathrm{f}\end{array}$ & $\mathrm{H}$ & $\mathrm{T}$ & $\begin{array}{l}52 \mathrm{~m} \\
300 \mathrm{f}\end{array}$ & Lambin (1994) \\
\hline $\begin{array}{l}\text { Microtus } \\
\text { xanthognathus }\end{array}$ & $135 \mathrm{~m} / \mathrm{f}$ & $\mathrm{S}$ & $\ldots$ & $0.3 \mathrm{~m} / \mathrm{f}$ & $\mathrm{H}$ & G & $\ldots$ & $\begin{array}{l}\text { Wolff and Lidicker } \\
\text { (1980) }\end{array}$ \\
\hline $\begin{array}{l}\text { Peromyscus } \\
\text { californicus }\end{array}$ & $0.018 \mathrm{~m} / \mathrm{f}$ & $\mathrm{D}$ & $\begin{array}{c}0.06 \mathrm{~m} \\
0.15 \mathrm{f}\end{array}$ & $\begin{array}{l}0.45 \mathrm{~m} \\
0.791 \mathrm{f}\end{array}$ & $\mathrm{H}$ & $\mathrm{T}$ & $\begin{array}{l}27 \mathrm{~m} \\
24 \mathrm{f}\end{array}$ & Ribble (1992) \\
\hline $\begin{array}{l}\text { Peromyscus } \\
\text { longicaudus }\end{array}$ & $0.008 \mathrm{~m} / \mathrm{f}$ & $\mathrm{S}$ & $\cdots$ & $\begin{array}{c}0.228 \mathrm{~m} \\
0.235 \mathrm{f}\end{array}$ & $\mathrm{H}$ & $\mathrm{T}$ & $\begin{array}{c}1 \mathrm{~m} \\
1 \mathrm{f}\end{array}$ & $\begin{array}{l}\text { Allred and Beck } \\
\text { (1963) }\end{array}$ \\
\hline $\begin{array}{l}\text { Peromyscus } \\
\text { maniculatus }\end{array}$ & $0.015 \mathrm{~m} / \mathrm{f}$ & $\mathrm{D}$ & $\begin{array}{c}0.05 \mathrm{~m} \\
0.15 \mathrm{f}\end{array}$ & $\begin{array}{l}0.883 \mathrm{~m} \\
1.005 \mathrm{f}\end{array}$ & $\mathrm{O}$ & $\mathrm{T}$ & $\begin{array}{l}71 \mathrm{~m} \\
64 \mathrm{f}\end{array}$ & $\begin{array}{l}\text { Dice and Howard } \\
\text { (1951) }\end{array}$ \\
\hline
\end{tabular}




\begin{tabular}{|c|c|c|c|c|c|c|c|c|}
\hline $\begin{array}{l}\text { Apodemus } \\
\text { sylvaticus }\end{array}$ & $0.020 \mathrm{~m} / \mathrm{f}$ & S & $\ldots$ & $0.5 \mathrm{~m} / \mathrm{f}$ & $\mathrm{H}$ & $\mathrm{N}$ & $\begin{array}{l}261 \\
\mathrm{~m} / \mathrm{f}\end{array}$ & $\begin{array}{c}\text { Dickman and } \\
\text { Doncaster (1989) }\end{array}$ \\
\hline $\begin{array}{l}\text { Ondatra } \\
\text { zibethicus }\end{array}$ & $1.048 \mathrm{~m} / \mathrm{f}$ & $S$ & $\ldots$ & $3.37 \mathrm{~m} / \mathrm{f}$ & $\mathrm{H}$ & $\mathrm{T}$ & $\ldots$ & Fitch (1958) \\
\hline $\begin{array}{l}\text { Ochotona } \\
\text { princeps }\end{array}$ & $\ldots$ & $\mathrm{D}$ & $0.09 \mathrm{~m} / \mathrm{f}$ & $0.396 \mathrm{~m} / \mathrm{f}$ & $\mathrm{H}$ & $\mathrm{G}$ & $\begin{array}{l}15 \\
\mathrm{~m} / \mathrm{f}\end{array}$ & $\begin{array}{c}\text { Peacock and Smith } \\
\text { (1997) }\end{array}$ \\
\hline $\begin{array}{l}\text { Lepus } \\
\text { americanus }\end{array}$ & $1.43 \mathrm{~m} / \mathrm{f}$ & S & $\ldots$ & $20.1 \mathrm{~m} / \mathrm{f}$ & $\mathrm{H}$ & $\mathrm{T}$ & 3 & O'Farrell (1965) \\
\hline Lepus europea & $4.50 \mathrm{~m} / \mathrm{f}$ & S & $\ldots$ & $9.0 \mathrm{~m} / \mathrm{f}$ & $\mathrm{H}$ & $\mathrm{T}$ & 11 & $\begin{array}{l}\text { Broekhuisen and } \\
\text { Maaskamp (1982) }\end{array}$ \\
\hline Lepus timidus & $2.750 \mathrm{~m} / \mathrm{f}$ & S & $3.0 \mathrm{~m} / \mathrm{f}$ & $200 \mathrm{~m} / \mathrm{f}$ & $\mathrm{H}$ & $\mathrm{N}$ & $\begin{array}{l}99 \\
\mathrm{~m} / \mathrm{f}\end{array}$ & $\begin{array}{c}\text { Angerbjörn and Flux } \\
\text { (1995) }\end{array}$ \\
\hline $\begin{array}{l}\text { Lepus } \\
\text { californicus }\end{array}$ & $2.2 \mathrm{~m} / \mathrm{f}$ & S & $\ldots$ & $45 \mathrm{~m} / \mathrm{f}$ & $\mathrm{H}$ & $\mathrm{N}$ & $\ldots$ & Best (1996) \\
\hline $\begin{array}{l}\text { Sylvilagus } \\
\text { bachmani }\end{array}$ & $0.841 \mathrm{~m} / \mathrm{f}$ & $S$ & $\ldots$ & $0.352 \mathrm{~m} / \mathrm{f}$ & $\mathrm{H}$ & $\mathrm{N}$ & $\begin{array}{l}148 \\
\mathrm{~m} / \mathrm{f}\end{array}$ & Shields (1960) \\
\hline $\begin{array}{l}\text { Sylvilagus } \\
\text { floridanus }\end{array}$ & $\begin{array}{l}1.10 \mathrm{~m} \\
1.20 \mathrm{f}\end{array}$ & $S$ & $\ldots$ & $\begin{array}{l}3.9 \mathrm{~m} \\
2.3 \mathrm{f}\end{array}$ & $\mathrm{H}$ & $\mathrm{T}$ & $\begin{array}{l}65 \\
\mathrm{~m} / \mathrm{f}\end{array}$ & $\begin{array}{l}\text { Chapman and } \\
\text { Trethewey (1972) }\end{array}$ \\
\hline $\begin{array}{l}\text { Odocoileus } \\
\text { hemionus } \\
\text { columbianus }\end{array}$ & $\begin{array}{c}64.638 \\
\mathrm{~m} / \mathrm{f}\end{array}$ & $\mathrm{D}$ & $\begin{array}{l}4.0 \mathrm{~m} \\
2.0 \mathrm{f}\end{array}$ & $\begin{array}{l}15.2 \mathrm{~m} \\
12.2 \mathrm{f}\end{array}$ & $\mathrm{H}$ & G & $\begin{array}{c}26 \mathrm{~m} \\
14 \mathrm{f}\end{array}$ & $\begin{array}{c}\text { Bunnell and Harestad } \\
\text { (1983) }\end{array}$ \\
\hline $\begin{array}{l}\text { Odocoileus } \\
\text { hemionus } \\
\text { hemionus }\end{array}$ & $\begin{array}{l}82.5 \mathrm{~m} \\
51.75 \mathrm{f}\end{array}$ & $S$ & $\ldots$ & $\begin{array}{l}7.34 \mathrm{~m} \\
8.22 \mathrm{f}\end{array}$ & $\mathrm{H}$ & G & $\begin{array}{l}65 \mathrm{~m} \\
33 \mathrm{f}\end{array}$ & Robinette (1966) \\
\hline $\begin{array}{l}\text { Odocoileus } \\
\text { virginianus }\end{array}$ & $86.41 \mathrm{f}$ & S & $\ldots$ & $11.74 \mathrm{f}$ & $\mathrm{H}$ & G & $7 \mathrm{f}$ & $\begin{array}{c}\text { Nelson and Mech } \\
\text { (1992) }\end{array}$ \\
\hline $\begin{array}{l}\text { Odocoileus } \\
\text { virginianus }\end{array}$ & $86.41 \mathrm{f}$ & $\mathrm{D}$ & $\begin{array}{l}6.0 \mathrm{~m} \\
24.0 \mathrm{f}\end{array}$ & $\ldots$ & $\mathrm{H}$ & G & $\begin{array}{c}26 \mathrm{~m} \\
4 \mathrm{f}\end{array}$ & Nelson (1993) \\
\hline Alces alces & $\begin{array}{c}481.83 \\
\mathrm{~m} / \mathrm{f}\end{array}$ & $S$ & $\ldots$ & 118.0 & $\mathrm{H}$ & $\mathrm{T}$ & 87 & Pullianen (1974) \\
\hline $\begin{array}{l}\text { Cervus } \\
\text { canadensis }\end{array}$ & $\begin{array}{l}315 \mathrm{~m} \\
225 \mathrm{f}\end{array}$ & $S$ & $\ldots$ & $18.5 \mathrm{~m} / \mathrm{f}$ & $\mathrm{H}$ & $\mathrm{T}$ & $5 \mathrm{~m} / \mathrm{f}$ & Brazda (1953) \\
\hline
\end{tabular}

\section{LITERATURE CITED}

Ables, E. D. 1965. An exceptional fox movement. Journal of Mammalogy 46: 102.

Adamcik, R. S., and L. B. Keith. 1978. Regional movements and mortality of great horned owls in relation to snowshoe hare fluctuations. Canadian Field-Naturalist 92: 228-234.

Allen, R. W., and M. M. Nice. 1952. A study of the breeding biology of the purple martin (Progne subis).
American Midland Naturalist 47: 606-645.

Allen, S. H., and A. B. Sargent. 1993. Dispersal patterns of red foxes relative to population density. Journal of Wildlife Management 57: 526-533.

Allred, D. M., and D. E. Beck. 1963. Range of movement and dispersal of some rodents at the Nevada atomic test site. Journal of Mammalogy 44: 190-200.

Anders, A. D., J. Faaborg, and F. Thompson III. 1998. Postfledging dispersal, habitat use, and home-range size of 
juvenile wood thrushes. Auk 115: 349-358.

Andrews, R. D., and E. K. Boggess. 1978. Ecology of coyotes in Iowa. Pages 249-265 in M. Bekoff, editor. Coyotes: biology, behavior, and management. Academic Press, New York, New York, USA.

Angerbjörn, A., and J. E. C. Flux. 1995. Lepus timidus. Mammalian Species 495: 1-11.

Arcese, P. 1989. Intrasexual competition, mating system, and natal dispersal in song sparrows. Animal Behaviour 38: 958-979.

Armitage, K. B. 1974. Male behaviour and territoriality in the yellow-bellied marmot. Journal of Zoology (London) 172: $233-265$.

Armitage, K. B., and J. F. Downhower. 1974. Demography of yellow-bellied marmot populations. Ecology 55: 1233-1245.

Arthur, S. M., T. F. Paragi, and W. B. Krohn. 1993. Dispersal of juvenile fishers in Maine. Journal of Wildlife Management 57: 868-874.

Badyaev, A. V., D. D. Gibson, and B. Kessel. 1996. White Wagtail, Montacilla alba. In A. Poole and F. Gill, editors. The Birds of North America. Number 236/237. The Birds of North America, Inc., Philadelphia, Pennsylvania, USA.

Baker, M. C., and L. R. Mewaldt. 1978. Song dialects as barriers to dispersal in white-crowned sparrows, Zonotrichia leucophrys nuttalli. Evolution 32: 712-722.

Baker, R. R. 1993. The function of post-fledging exploration: a pilot study of three species of passerines ringed in Britain. Ornis Scandinavica 24: 71-79.

Ballard, W. B., J. S. Whitman, and C. L. Gardner. 1987. Ecology of an exploited wolf population in south-central Alaska. Wildlife Monographs 98: 1-54.

Beaudette, P. D., and D. M. Keppie. 1992. Survival of dispersing spruce grouse. Canadian Journal of Zoology 70: 693-697.

Bednarz, J. C. 1995. Harris' Hawk, Parabuteo unicinctus. In A. Poole and F. Gill, editors. The Birds of North America. Number 146. Academy of Natural Sciences, Philadelphia, Pennsylvania, USA, and American Ornithologists' Union, Washington, D.C., USA.

Beissinger, S. R., and M. I. Westphal. 1998. On the use of demographic models of population viability in endangered species management. Journal of Wildlife Management 62: 821-841.

Belant, J. L., and R. A. Dolbeer. 1993. Migration and dispersal of Laughing Gulls in the United States. Journal of Field Ornithology 64: 557-565.
Belthoff, J. R., and G. Ritchison. 1989. Natal dispersal of Eastern Screech-Owls. Condor 91: 254-265.

Bengtsson, B. O. 1978. Avoiding inbreeding, at what cost? Journal of Theoretical Biology 73: 439-444.

Berg, W. E., and D. W. Kuehn. 1982. Ecology of wolves in north-central Minnesota. Pages 4-11 in F. C. Harrington and P. C. Paquet, editors. Wolves of the world: perspectives of behavior, ecology and conservation. Noyes, Park Ridge, New Jersey, USA.

Berndt, R., and H. Sternberg. 1968. Terms, studies and experiments on the problems of bird dispersion. Ibis 110: 256-269.

Best, T. L. 1996. Lepus californicus. Mammalian Species 530: $1-10$.

Bjorge, R. R., J. B.Gunson, and W. M. Samuel. 1981. Population characteristics and movements of striped skunks (Mephitis mephitis) in Central Alberta. Canadian FieldNaturalist 95: 149-155.

Bowen, W. D. 1982. Home range and spatial organization of coyotes in Jasper National Park, Alberta. Journal of Wildlife Management 46: 201-216.

Bowman, T. J., and R. J. Robel. 1977. Brood break-up, dispersal, mobility, and mortality of juvenile prairie chickens. Journal of Wildlife Management 41: 27-34.

Boyce, C. C. K., and J. L. Boyce III. 1988. Population biology of Microtus arvalis. II. Natal and breeding dispersal of females. Journal of Animal Ecology 57: 723-736.

Brazda, A. R. 1953. Elk migration patterns and some of the factors affecting movements in the Gallatin River Drainage, Montana. Journal of Wildlife Management 17: 9-23.

Broekhuizen, S., and F. Maaskamp. 1982. Movement, home range, and clustering in the European hare. Zeitschrift fur Saugertierkunde 47: 22-32.

Brooker, L., M. Brooker, and P. Cale. 1999. Animal dispersal in fragmented habitat: measuring habitat connectivity, corridor use, and dispersal mortality. Conservation Ecology 3(1): 4. [online] URL: http://www.consecol.org/vol3/iss1/art4

Brown, J. H., and B. A. Maurer. 1989. Macroecology: the division of food and space among species on continents. Science 243: 1145-1150.

Bull, E. L., and J. R. Duncan. 1993. Great Gray Owl, Strix nebulosa. In A. Poole and F. Gill, editors. The Birds of North America. Number 41. Academy of Natural Sciences, Philadelphia, Pennsylvania, USA, and American Ornithologists' Union, Washington, D.C., USA.

Bull, E. L., and J. A. Jackson. 1995. Pileated Woodpecker, Dryocopus pileatus. In A. Poole and F. Gill, editors. The 
Birds of North America. Number 148. Academy of Natural Sciences, Philadelphia, Pennsylvania, USA, and American Ornithologists' Union, Washington, D.C., USA.

Bunnell, F. L. 1999. What habitat is an island? Pages 1-31 in J. A. Rochelle, L. A. Lehmann, and J. Wisniewski, editors. Forest fragmentation: wildlife and management implications. Brill, Boston, Massachusetts, USA.

Bunnell, F. L., and A. S. Harestad. 1983. Dispersal and dispersion of black-tailed deer: models and observations. Journal of Mammalogy 64: 201-209.

Bunnell, F. L., and D. J. Huggard. 1999. Biodiversity across spatial and temporal scales: problems and opportunities. Forest Ecology and Management 115: 113126.

Bunnell, F. L., and L. L. Kremsater. 1990. Sustaining wildlife in managed forests. Northwest Environmental Journal 6: 243-269.

Butler, R. W., N. A. M. Verbeek, and R. G. Foottit. 1980. Mortality and dispersal of the glaucous-winged gulls of southern British Columbia. Canadian Field-Naturalist 94: 315-320.

Caley, J. M. 1991. A null model for testing distributions of dispersal distances. American Naturalist 138: 524-532.

Carraway, L. N., L. F. Alexander, and B. J. Verts. 1993. Scapanus townsendii. Mammalian Species 434: 1-7.

Cates, S. E., and J. L. Gittleman. 1997. Reading between the lines-is allometric scaling useful? Trends in Ecology and Evolution 12: 338-339.

Chapman, J. A., and D. E. C. Trethewey. 1972. Movements within a population of introduced eastern cottontail rabbits. Journal of Wildlife Management 36: 155158.

Chapman, L. B. 1955. Studies of a tree swallow colony. Bird-Banding 26: 45-70.

Cheesman, C. L., W. J. Creswell, S. Harris, and P. J. Mallinson. 1988. Comparison of dispersal and other movements in two badger (Meles meles) populations. Mammal Review 18: 51-59.

Ciaranca, M. A., C. C. Allin, and G. S. Jones. 1997. Mute Swan, Cygnus olor. In A. Poole and F. Gill, editors. The Birds of North America. Number 273. Academy of Natural Sciences, Philadelphia, Pennsylvania, USA, and American Ornithologists' Union, Washington, D.C., USA.

Clarke, A. L., B.-E. Saether, and E. Roskaft. 1997. Sex biases in avian dispersal: a reappraisal. Oikos 79: 429-438.

Cleveland, W. S., E. Grosse, and W. M. Shyu. 1992. Local regression models. Pages 309-376 in J. M. Chambers and T. J. Hastie, editors. Statistical models in S. Wadsworth
\& Brooks, Pacific Grove, California, USA.

Clutton-Brock, T. H. 1988. Reproductive success. Pages 472-485 in Clutton-Brock, T. H., editor. Studies of individual variation in contrasting breeding systems. University of Chicago Press, Chicago, Illinois, USA.

Collister, D. M., and K. De Smet. 1997. Breeding and natal dispersal in the Loggerhead Shrike. Journal of Field Ornithology 68: 273-282.

Cook, R. D. 1977. Detection of influential observation in linear regression. Technometrics 19: 15-18.

Cowan, P. E., R. E. Brockie, G. D. Ward, and M. G. Efford. 1996. Long-distance movements of juvenile brushtail possums (Trichosurus vulpecula) on farmland, Hawke's Bay, New Zealand. Wildlife Research 23: 237-244.

Crocoll, S. T. 1994. Red-shouldered Hawk, Buteo lineatus. In A. Poole and F. Gill, editors. The Birds of North America. Number 107. Academy of Natural Sciences, Philadelphia, Pennsylvania, USA, and American Ornithologists' Union, Washington, D.C., USA.

Daly, J. C., and J. L. Patton. 1990. Dispersal, gene flow, and allelic diversity between local populations of Thomomys bottae pocket gophers in the coastal ranges of California. Evolution 44: 1283-1294.

Dice, L. R., and W. E. Howard. 1951. Distance of dispersal by prairie deermice from birthplaces to breeding sites. University of Michigan, Contributions from the Laboratory of Vertebrate Biology 50: 1-13.

Dickman, C. R., and C. P. Doncaster. 1989. The ecology of small mammals in urban habitats. II. Demography and dispersal. Journal of Animal Ecology 58: 119-127.

Doak, D. F., P. C. Marino, and P. M. Karieva. 1992. Spatial scale mediates the influence of habitat fragmentation on dispersal success: implications for conservation. Theoretical Population Biology 41: 315-336.

Dobson, F. S. 1982. Competition for mates and predominant juvenile male dispersal in mammals. Animal Behaviour 30: 1183-1192.

Dobson, F. S., and W. T. Jones. 1985. Multiple causes of dispersal. American Naturalist 126: 855-858.

Dow, H., and S. Fredga. 1983. Breeding and natal dispersal of the goldeneye, Bucephala clangula. Journal of Animal Ecology 52: 681-695.

Dugger, B. D., K. M. Dugger, and L. H. Fredrickson. 1994. Hooded Merganser, Lophodytes cucullatus. In A. Poole and F. Gill, editors. The Birds of North America. Number 98. Academy of Natural Sciences, Philadelphia, Pennsylvania, USA, and American Ornithologists' Union, Washington, D.C., USA. 
Dunk, J. R. 1995. White-tailed Kite, Elanus leucurus. In A. Poole and F. Gill, editors. The Birds of North America. Number 178. Academy of Natural Sciences, Philadelphia, Pennsylvania, USA, and American Ornithologists' Union, Washington, D.C., USA.

Dunning, J. B. 1993. CRC handbook of avian body masses. CRC Press, Boca Raton, Florida, USA.

Eaton, S. W. 1992. Wild Turkey, Meleagris gallopavo. In A. Poole and F. Gill, editors. The Birds of North America. Number 22. Academy of Natural Sciences, Philadelphia, Pennsylvania, USA, and American Ornithologists' Union, Washington, D.C., USA.

Eden, S. F. 1987. Natal philopatry of the magpie Pica pica. Ibis 129: 477-490.

Efron, B., and R. J. Tibshirani. 1993. An introduction to the bootstrap. Chapman and Hall, San Francisco, California, USA.

Ehrlich, P. R., D. S. Dobkin, and D. Wheye. 1988. The birder's handbook: a field guide to the natural history of North American birds. Simon and Schuster, New York, New York, USA.

Erlinge, S. 1977. Spacing strategy in stoat Mustela erminea. Oikos 28: 32-42.

Evans, F. C., and R. Holdenried. 1943. A population study of the Beechey ground squirrel in central California. Journal of Mammalogy 24: 231-260.

Fahrig, L. 1997. Relative effects of habitat loss and fragmentation on population extinction. Journal of Wildlife Management 61: 603-610.

Fahrig, L., and H. G. Merriam. 1985. Habitat patch connectivity and population survival. Ecology 66: 17621768.

Fang, Y., and Y.-H. Sun. 1997. Brood movement and natal dispersal of hazel grouse Bonasa bonasia at Changbai Mountain, Jilin Province, China. Wildlife Biology 3: 261264.

Felsenstein, J. 1985. Phylogenies and the comparative method. American Naturalist 125: 1-15.

Ferrer, M. 1993. Ontogeny of dispersal distances in young Spanish Imperial Eagles. Behavioral Ecology and Sociobiology 32: 259-263.

Fitch, H. S. 1958. Home ranges, territories, and seasonal movements of vertebrates of the Natural History Reservation. University of Kansas Publications, Museum of Natural History 11: 63-326.

Franklin, J. F., D. R. Berg, D. A. Thornburgh, and J. C. Tappeiner. 1997. Alternative silvicultural approaches to timber harvesting: variable retention harvest systems. Pages
111-139 in K. A. Kohm and J. F. Franklin, editors. Creating a forestry for the 21st century. Island Press, Washington, D.C., USA.

Gabrey, S. W. 1996. Migration and dispersal in Great Lakes Ring-billed and Herring Gulls. Journal of Field Ornithology 67: 327-339.

Gauthier, G. 1993. Bufflehead, Bucephala albeola. In A. Poole and F. Gill, editors. The Birds of North America. Number 67. Academy of Natural Sciences, Philadelphia, Pennsylvania, USA, and American Ornithologists' Union, Washington, D.C., USA.

Gehlbach, F. R. 1986. Odd couples of suburbia. Natural History 6: 56-66.

Gese, E. M., and L. D. Mech. 1991. Dispersal of wolves (Canis lupus) in northeastern Minnesota, 1969-1989. Canadian Journal of Zoology 69: 2946-2955.

Giesen, K. M., and C. E. Braun. 1993. Natal dispersal and recruitment of juvenile White-tailed Ptarmigan in Colorado. Journal of Wildlife Management 57: 72-77.

Glenn, L. P., and L. H. Miller. 1980. Seasonal movements of an Alaska peninsula brown bear population. Pages 307312 in Fourth International Conference on Bear Research and Management (Kalispell, Montana, USA, 1977). The Bear Biology Association and the Bureau of Land Management, Tonto, Arizona, USA.

Greenwood, P. J. 1980. Mating systems, philopatry, and dispersal in birds and mammals. Animal Behaviour 28: 1140-1162.

Greenwood, P. J., and P. J. Harvey. 1977. Feeding strategies and dispersal of territorial passerines: a comparative study of the blackbird Turdus merula and the greenfinch Charduelis chloris. Ibis 119: 528-531.

Greenwood, P. J., and P. J. Harvey. 1982. The natal and breeding dispersal of birds. Annual Review of Ecology and Systematics 13: 1-21.

Greenwood, P. J., P. J. Harvey, and C. M. Perrins. 1979. The role of dispersal in the great tit (Parus major): the causes, consequences and heritability of natal dispersal. Journal of Animal Ecology 48: 123-142.

Gutiérrez, R. J., A. B. Franklin, W. Lahaye, V. J . Meretsky, and J. P. Ward. 1985. Juvenile spotted owl dispersal in northwestern California: preliminary results. Pages 60-65 in R. J. Gutiérrez, and A. B. Carey, editors. Ecology and management of the spotted owl in the Pacific Northwest. U.S. Forest Service General Technical Report PNW-GTR-185.

Haig, S. M., and L. W. Oring. 1988. Distribution and dispersal in the Piping Plover. Auk 105: 630-638.

Halliburton, R., and L. R. Mewaldt. 1976. Survival and 
mobility in a population of Pacific Coast Song Sparrows (Melospiza melodia gouldii). Condor 78: 499-504.

Hansen, A. J., T. A. Spies, F. J. Swanson, and J. L. Ohmann. 1991. Conserving biodiversity in managed forests. BioScience 41: 382-392.

Hanski, I., A. Peltonen, and L. Kaski. 1991. Natal dispersal and social dominance in the common shrew Sorex araneus. Oikos 62: 48-58.

Harestad, A. S., and F. L. Bunnell. 1979. Home range and body weight—a re-evaluation. Ecology 60: 389-402.

Harris, L. D. 1984. The fragmented forest. University of Chicago Press, Chicago, Illinois, USA.

Haug, E. A., B. A. Millsap, and M. S. Martell. 1993. Burrowing Owl, Speotyto cunicularia. In A. Poole and F. Gill, editors. The Birds of North America. Number 61. Academy of Natural Sciences, Philadelphia, Pennsylvania, USA, and American Ornithologists' Union, Washington, D.C., USA.

Hedrick, P. H. 1996. Genetics of metapopulations: aspects of a comprehensive perspective. Pages 29-51 in D. R. McCullough, editor. Metapopulations and wildlife conservation. Island Press, Washington, D.C., USA.

Henein, K., and G. Merriam. 1990. The elements of connectivity where corridor quality is variable. Landscape Ecology 4: 157-170.

Henein, K., J. Wegner, and G. Merriam. 1998. Population effects of landscape model manipulation on two behaviourally different woodland small mammals. Oikos 81:168-186.

Hengeveld, R. 1994. Small step invasion research. Trends in Ecology and Evolution 9: 339-342.

Hepp, G. R., and F. C. Bellrose. 1995. Wood Duck, Aix sponsa. In A. Poole and F. Gill, editors. The Birds of North America. Number 169. Academy of Natural Sciences, Philadelphia, Pennsylvania, USA, and American Ornithologists' Union, Washington, D.C., USA.

Hines, J. E. 1986. Survival and reproduction of dispersing Blue Grouse. Condor 88: 43-49.

Hobson, K. A. 1997. Pelagic Cormorant, Phalacrocorax pelagicus. In A. Poole and F. Gill, editors. The Birds of North America. Number 282. Academy of Natural Sciences, Philadelphia, Pennsylvania, USA, and American Ornithologists' Union, Washington, D.C., USA.

Hogg, R. V., and E. A. Tanis. 1997. Probability and statistical inference. Prentice Hall, Upper Saddle River, New Jersey, USA.

Holekamp, K. E. 1984. Natal dispersal in Belding's ground squirrels (Spermophilus beldingi). Behavioral Ecology and
Sociobiology 16: 21-30.

Holling, C. S. 1992. Cross-scale morphology, geometry, and dynamics of ecosystems. Ecological Monographs 62: 447-502.

Hopp, S .L., A. Kirby, and C. A. Boone. 1995. White-eyed Vireo, Vireo griseus. In A. Poole and F. Gill, editors. The Birds of North America. Number 168. Academy of Natural Sciences, Philadelphia, Pennsylvania, USA, and American Ornithologists' Union, Washington, D.C., USA.

Howard, W. E. 1960. Innate and environmental dispersal of individual vertebrates. American Midland Naturalist 63: 152-161.

Ibrahim, K. M., R. A. Nichols, and G. M. Hewitt. 1996. Spatial patterns of genetic variation generated by different forms of dispersal during range expansion. Heredity 77: 282-291.

Jackson, J. A. 1994. Red-cockaded Woodpecker, Picoides borealis. In A. Poole and F. Gill, editors. The Birds of North America. Number 85. Academy of Natural Sciences, Philadelphia, Pennsylvania, USA, and American Ornithologists' Union, Washington, D.C., USA.

James, P. C., I. G. Warkentin, and L. W. Oliphant. 1989. Turnover and dispersal in urban merlins Falco columbarius. Ibis 131: 425-447.

Jamieson, I. G., and F. C. Zwickel. 1983. Dispersal and site fidelity in blue grouse. Canadian Journal of Zoology 61: $570-573$.

Jensen, B. 1973. Movements of the red fox (Vulpes vulpes L.) in Denmark investigated by marking and recovery. Danish Review of Game Biology 8: 1-20.

Johnson, R. F. 1956. Population structure in salt marsh song sparrows. Part I. Environment and annual cycle. Condor 58: 24-44.

Jones, W. T. 1987. Dispersal patterns in kangaroo rats (Dipodomys spectabilis). Pages 119-127 in B. D. ChepkoSade and Z. T. Halpin, editors. Mammalian dispersal patterns: the effects of social structure on population genetics. University of Chicago Press, Chicago, Illinois, USA.

Jones, W. T. 1989. Dispersal distance and the range of nightly movements in Merriam's kangaroo rats. Journal of Mammalogy 70: 27-34.

Koenig, W. D., D. V. Vuren, and P. N. Hooge. 1996. Detectability, philopatry, and the distribution of dispersal distances in vertebrates. Trends in Ecology and Evolution 11: 514-517.

Korpimäki, E. 1987. Selection for nest-hole shift and tactics of breeding dispersal in Tengmalm's owl Aegolius funereus. Journal of Animal Ecology 56: 185-196. 
Korpimäki, E., and M. Lagerström. 1988. Survival and natal dispersal of fledglings of Tengmalm's owl in relation to fluctuating food conditions and hatching date. Journal of Animal Ecology 57: 433-441.

Kot, M., M. A. Lewis, and P. van den Driessche. 1996. Dispersal data and the spread of invading organisms. Ecology 77: 2027-2042.

Kozlowski, J., and J. Weiner. 1997. Interspecific allometries are by-products of body size optimization. American Naturalist 149: 352-380.

Kunkele, J., and D. von Holst. 1996. Natal dispersal in the European wild rabbit. Animal Behaviour 51: 1047-1059.

Kushlan, J. A., and K. L. Bildstein. 1992. White Ibis, Eudocimus albus. In A. Poole and F. Gill, editors. The Birds of North America. Number 9. Academy of Natural Sciences, Philadelphia, Pennsylvania, USA, and American Ornithologists' Union, Washington, D.C., USA.

LaBarbera, M. 1989. Analyzing body size as a factor in ecology and evolution. Annual Review of Ecology and Systematics 20: 97-117.

Lamberson, R. H., B. R. Noon, C. Voss, and K. McKelvey. 1994. Reserve design for territorial species: the effects of patch size and spacing on the viability of the Northern Spotted Owl. Conservation Biology 8: 185-195.

Lambin, X. 1994. Natal philopatry, competition for resources, and inbreeding avoidance in Townsend's voles (Microtus townsendii). Ecology 75: 224-235.

Lariviere, S., and L. R. Walton. 1997. Lynx rufus. Mammalian Species 563: 1-8.

Leege, T. A. 1963. Natural movements of beavers in southeastern Idaho. Journal of Wildlife Management 32: 973-976.

Lehmkuhl, J. F., and L. F. Ruggiero. 1991. Forest fragmentation in the Pacific Northwest and its potential effects on wildlife. Pages 35-46 in L. F. Ruggiero, K. B. Aubry, A. B. Carey, and M. F. Huff. Wildlife and vegetation of unmanaged Douglas-fir forests. U.S. Forest Service, Pacific Research Station, General Technical Report PNWGTR-285.

Lessells, C. M. 1985. Natal and breeding dispersal of Canada geese Branta canadensis. Ibis 127: 31-41.

Lindzey, P. G. 1978. Movement patterns of badgers in northwestern Utah. Journal of Wildlife Management 42: 418-422.

Löfgren, O., B. Hörnfeldt, and B.-G. Carlsson. 1986. Site tenacity and nomadism in Tengmalm's owl (Aegolius funereus (L.)) in relation to cyclic food production. Oecologia 69: 321-326.
Lofroth, E. C. 1993. Scale dependent analyses of habitat selection by marten in the sub-boreal spruce biogeoclimatic zone, British Columbia. Thesis. Simon Fraser University, Burnaby, British Columbia, Canada.

Logan, K. A., L. L. Irwin, and R. Skinner. 1986. Characteristics of a hunted mountain lion population in Wyoming. Journal of Wildlife Management 50: 648-654.

Lowther, P. E. 1993. Brown-headed Cowbird, Molothrus ater. In A. Poole and F. Gill, editors. The Birds of North America. Number 47. Academy of Natural Sciences, Philadelphia, Pennsylvania, USA, and American Ornithologists' Union, Washington, D.C., USA.

Lynch, G. M. 1967. Long-range movement of a raccoon in Manitoba. Journal of Mammalogy 48: 659-660.

Mace, G. M., P. H. Harvey, and T. H. Clutton-Brock. 1982. Vertebrate home-range size and energetic requirements. Pages 32-53 in I. R. Swingland and P. J. Greenwood, editors. The ecology of animal movement. Oxford University Press, Oxford, UK.

Marcström, V., and R. Kenward. 1981. Movements of wintering goshawks in Sweden. Viltrevy 12: 1-36.

Martin, K. 1998. The role of animal behavior studies in wildlife science and management. Wildlife Society Bulletin 26: $911-920$.

Martin, K., and S. J. Hannon. 1987. Natal philopatry and recruitment of willow ptarmigan in north central and northwestern Canada. Oecologia 71: 518-524.

Marzluff, J. M., and R. P. Balda. 1989. Causes and consequences of female-biased dispersal in a flock-living bird, the Pinyon Jay. Ecology 70: 316-328.

Mathsoft, Inc. 1998. SPLUS 4 Guide to Statistics. Mathsoft, Seattle, Washington, USA.

Mattysen, E., and K.-H. Schmidt. 1987. Natal dispersal in the nuthatch. Ornis Scandinavica 18: 313-316.

McGuire, B., L. L. Getz, J. E. Hofman, T. Pizzuto, and B. Frase. 1993. Natal dispersal and philopatry in prairie voles (Microtus ochrogaster) in relation to population density, season, and natal social environment. Behavioral Ecology and Sociobiology 32: 293-302.

McNab, B. T. 1963. Bioenergetics and the determination of home range size. American Naturalist 97: 133-140.

Mead, C. J. 1979. Colony fidelity and interchange in the sand martin. Bird Study 26: 99-106.

Mearns, R., and I. Newton. 1982. Turnover and dispersal in a peregrine Falco peregrinus population. Ibis 126: 347355 .

Mech, L. D. 1987. Age, season, distance, direction, and 
social aspects of wolf dispersal from a Minnesota pack. Pages 55-74 in B. D. Chepko-Sade and Z. T. Halpin, editors. Mammalian dispersal patterns: the effects of social structure on population genetics. University of Chicago Press, Chicago, Illinois, USA.

Melquist, W. E., and H. G. Hornocker. 1983. Ecology of river otters in west central Idaho. Wildlife Monographs 83: 1-60.

Merriam, G. 1998. Biodiversity at the population level: a vital paradox. Pages 45-65 in F. L. Bunnell and J. F. Johnson, editors. Policy and practices for biodiversity in managed forests: the living dance. University of British Columbia Press, Vancouver, British Columbia, Canada.

Mihok, S., T. Lawton, and B. Schwartz. 1988. Fates and movements of meadow voles (Microtus pennsylvanicus) following a population decline. Canadian Journal of Zoology 66: 323-328.

Miller, G. L., and B. W. Carroll. 1989. Modeling dispersal distances: alternatives to the geometric distribution. Ecology 70: $977-986$.

Miller, G. S., and E. C. Meslow. 1985. Dispersal data for juvenile spotted owls: the problem of small sample size. Pages 69-73 in R. J. Gutiérrez and A. B. Carey, editors. Ecology and management of the spotted owl in the Pacific Northwest. U.S. Forest Service General Technical Report GTR PNW-185.

Miller, G. S., R. J. Small, and E. C. Meslow. 1997. Habitat selection by spotted owls during natal dispersal in western Oregon. Journal of Wildlife Management 61: 140150 .

Miller, K. E., and J. A. Smallwood. 1997. Natal dispersal and philopatry of southeastern American Kestrels in Florida. Wilson Bulletin 109: 226-232.

Mills, L. S., and F. W. Allendorf. 1996. The one-migrantper-generation rule in conservation and management. Conservation Biology 10: 1509-1518.

Mitchell, J. L. 1961. Mink movements and populations on a Montana river. Journal of Wildlife Management 25: 48-54.

Mitchell, C. D. 1994. Trumpeter Swan, Cygnus buccinator. In A. Poole and F. Gill, editors. The Birds of North America. Number 105. Academy of Natural Sciences, Philadelphia, Pennsylvania, USA, and American Ornithologists' Union, Washington, D.C., USA.

Mitchener, G. R., and D. R. Mitchener. 1977. Population structure and dispersal in Richardson's ground squirrels. Ecology 58: 359-368.

Moore, J., and R. Ali. 1984. Are dispersal and inbreeding avoidance related? Animal Behaviour 32: 94-112.

Mueller, H. C., and D. D. Berger. 1967. Some observations and comments on the periodic invasions of goshawks. Auk 84: 183-191.

Neigel, J. E., and J. C. Avise. 1993. Application of a random walk to geographic distributions of animal mitochondrial DNA variation. Genetics 135: 1209-1220.

Nelson, M. E. 1993. Natal dispersal and gene flow in whitetailed deer in northeastern Minnesota. Journal of Mammalogy 74: 316-322.

Nelson, M. E., and L. D. Mech. 1992. Dispersal in female white-tailed deer. Journal of Mammalogy 73: 891-894.

Newton, I., editor. 1989. Lifetime reproduction in birds. Academic Press, London, UK.

Newton, I., and M. Marquiss. 1983. Dispersal of sparrowhawks between birthplace and breeding place. Journal of Animal Ecology 52: 463-477.

Nice, M. M. 1937. Studies in the life history of the song sparrow. I. A population study of the song sparrow. Transactions of the Linnean Society of New York 6: 1-328.

Nilsson, J. A. 1989. Causes and consequences of natal dispersal in the marsh tit, Parus palustris. Journal of Animal Ecology 58: 619-636.

O'Farrell, T. P. 1965. Home range and ecology of snowshoe hares in interior Alaska. Journal of Mammalogy 46: 406-418.

Oring, L. W., E. M. Gray, and J. M. Reed. 1997. Spotted Sandpiper, Actitis macularia. In A. Poole and F. Gill, editors. The Birds of North America. Number 289. Academy of Natural Sciences, Philadelphia, Pennsylvania, USA, and American Ornithologists' Union, Washington, D.C., USA.

Oring, L. W., and D. B. Lank. 1984. Breeding area fidelity, natal philopatry, and the social systems of sandpipers. Pages 125-147 in J. Burger and B. L. Olla, editors. Shorebirds: breeding behavior and populations. Plenum Press, New York, New York, USA.

Paradis, E., S. R. Baillie, W. J. Sutherland, and R. D. Gregory. 1998. Patterns of natal and breeding dispersal in birds. Journal of Animal Ecology 67: 518-536.

Pärt, T. 1990. Natal dispersal in the collared flycatcher: possible causes and reproductive consequences. Ornis Scandinavica 21: 83-88.

Pasitschniak-Arts, M., and S. Lariviere. 1995. Gulo gulo. Mammalian Species 499: 1-10.

Payne, R. B. 1991. Natal dispersal and population structure in a migratory songbird, the Indigo Bunting. Evolution 45: 49-62.

Peacock, M. M., and A. T. Smith. 1997. The effect of habitat fragmentation on dispersal patterns, mating 
behavior, and genetic variation in a pika (Ochonota princeps) metapopulation. Oecologia 112: 524-533.

Pearson, A. M. 1972. Population characteristics of the northern interior grizzly in the Yukon Territory, Canada. Pages 32-35 in Second International Conference of Bear Research and Management (Calgary, Alberta, Canada, 1970). International Union for Conservation of Nature and Natural Resources, Morges, Switzerland. IUCN Publication, New Series, Number 23.

Peltonen, A., and I. Hanski. 1991. Patterns of island occupancy explained by colonization and extinction rates in shrews. Ecology 72: 1698-1708.

Peters, R. H. 1983. The ecological implications of body size. Cambridge University Press, Cambridge, UK.

Peterson, G., C. R. Allen, and C. S. Holling. 1998. Ecological resilience, biodiversity and scale. Ecosystems 1: 6-18.

Phillips, R. L., R. D. Andrews, G. L. Storm, and R. A. Bishop. 1972. Dispersal and mortality of red foxes. Journal of Wildlife Management 36: 237-248.

Plissner, J. H., and P. A Gowaty. 1996. Patterns of natal dispersal, turnover, and dispersal costs in eastern bluebirds. Animal Behaviour 51: 1307-1322.

Porter, J. H., and J. L. Dooley. 1993. Animal dispersal patterns: a reassessment of simple mathematical models. Ecology 74: 2436-2443.

Post, W., J. P. Poston, and G. T. Bancroft. 1996. Boattailed Grackle, Quiscalus major. In A. Poole and F. Gill, editors. The Birds of North America. Number 207. Academy of Natural Sciences, Philadelphia, Pennsylvania, USA, and American Ornithologists' Union, Washington, D.C., USA.

Preston, C. R., and R. D. Beane. 1993. Red-tailed Hawk, Buteo jamaicensis. In A. Poole and F. Gill, editors. The Birds of North America. Number 52. Academy of Natural Sciences, Philadelphia, Pennsylvania, USA, and American Ornithologists' Union, Washington, D.C., USA.

Price, M. V., P. A. Kelly, and R. L. Goldingay. 1994. Distances moved by Stephens' kangaroo rat (Dipodomys stephensi Merriam) and implications for conservation. Journal of Mammalogy 75: 929-939.

Priewert, F. W. 1951. Record of an extensive movement by a raccoon. Journal of Mammalogy 42: 113.

Prothero, J. 1986. Methodological aspects of scaling in biology. Journal of Theoretical Biology 118: 259-286.

Pulliam, H. R., J. B. Dunning, Jr., and J. Liu. 1992. Population dynamics in complex landscapes: a case study. Ecological Applications 2: 165-177.

Pullianen, E. 1974. Seasonal movements of moose in
Europe. Naturaliste Canadien 101: 379-392.

Pusey, A. E. 1987. Sex-biased dispersal and inbreeding avoidance in birds and mammals. Trends in Ecology and Evolution 2: 295-299.

Rees, M. 1993. Null models and dispersal distributions: a comment on an article by Caley. American Naturalist 141: 812-815.

Rheinwald, G. 1975 . The pattern of settling distances in a population of House Martins Delichon urbica. Ardea 63: 136-145.

Ribble, D. O. 1992. Dispersal in a monogamous rodent. Ecology 73: 859-866.

Robinette, W. L. 1966. Mule deer home range and dispersal in Utah. Journal of Wildlife Management 30: 335349.

Robinson, G. R., R. D. Holt, M. S. Gaines, S. P. Hamburg, M. L. Johnson, H. S. Fitch, and E. S. Martinko. 1992. Diverse and contrasting effects of habitat fragmentation. Science 257: 524-527.

Robinson, J. A., and L. W. Oring. 1997. Natal and breeding dispersal in American Avocets. Auk 114: 416-430.

Robinson, W. B., and E. F. Grant. 1958. Comparative movements of bobcats and coyotes as disclosed by tagging. Journal of Wildlife Management 22: 117-122.

Robinson, W. D. 1995. Louisiana Waterthrush, Seiurus motacilla. In A. Poole and F. Gill, editors. The Birds of North America. Number 151. Academy of Natural Sciences, Philadelphia, Pennsylvania, USA, and American Ornithologists' Union, Washington, D.C., USA.

Rogers, L. L. 1987. Effects of food supply and kinship on social behavior, movements, and population growth of black bears in northeastern Minnesota. Wildlife Monographs 97: $1-72$.

Rongstad, O. J. 1965. A life history study of thirteen-lined ground squirrels in southern Wisconsin. Journal of Mammalogy 46: 76-87.

Rood, J. P. 1987. Dispersal and intergroup transfer in the dwarf mongoose. Pages 85-103 in B. D. Chepko-Sade and Z. T. Halpin, editors. Mammalian dispersal patterns. University of Chicago Press, Chicago, Illinois, USA.

Rosenfield, R. N., and J. Bielefeldt. 1992. Natal dispersal and inbreeding in the Cooper's Hawk. Wilson Bulletin 104: $182-184$

Ross, P. I., and M. G. Jalotsky. 1992. Characteristics of a hunted population of cougars in southwestern Alberta. Journal of Wildlife Management 56: 417-426.

Russell, E. M., and I. Rowley. 1993. Philopatry or 
dispersal: competition for territory vacancies in the splendid fairy-wren Malurus splendens. Animal Behaviour 45: 519539.

Sandell, M., J. Agrell, S. Erlinge, and J. Nelson. 1990. Natal dispersal in relation to population density and sex ratio in the field vole, Microtus agrestis. Oecologia 83: 145149.

Saunders, J. K. J. 1963. Movements and activities of the lynx in Newfoundland. Journal of Wildlife Management 27: 390-400.

Schoener, T. W. 1968. Sizes of feeding territories among birds. Ecology 49: 123-141.

Schmidt-Nielsen, K. 1984. Scaling: why is animal size so important? Cambridge University Press, Cambridge, UK.

Schroeder, M. A. 1986. The fall phase of dispersal in juvenile spruce grouse. Canadian Journal of Zoology 64: 16-20.

Schumaker, N. H. 1996. Using landscape indices to predict habitat connectivity. Ecology 77: 1210-1225.

Shaw, M. W. 1995. Simulation of population expansion and spatial pattern when individual dispersal distributions do not decline exponentially with distance. Proceedings of the Royal Society of London Series B. Biological Sciences 259: 243-248.

Shields, P. W. 1960. Movement patterns of brush rabbits in northwestern California. Journal of Wildlife Management 24: 381-386.

Shields, W. M. 1982. Optimal inbreeding and the evolution of philopatry. Pages 132-159 in I. R. Swingland and P. J. Greenwood, editors. The ecology of animal movement. Oxford University Press, Oxford, UK.

Shields, W. M. 1987. Dispersal and mating systems: investigating their causal connections. Pages 3-26 in B. D. Chepko-Sade and Z. T. Halpin, editors. Mammalian dispersal patterns. University of Chicago Press, Chicago, Illinois, USA.

Silva, M. 1998. Allometric scaling of body length: elastic or geometric similarity in mammalian design. Journal of Mammalogy 79: 20-32.

Silva, M., and J. A. Downing. 1995a. CRC Handbook of mammalian body masses. CRC, Boca Raton, Florida, USA.

Silva, M., and J. A. Downing. 1995b. The allometric scaling of density and body mass: a nonlinear relationship for terrestrial mammals. American Naturalist 145: 704-727.

Sinclair, A. R. E. 1992. Do large mammals disperse like small mammals? Pages 229-242 in N. C. Stenseth and W. Z. Lidicker, Jr., editors. Animal dispersal: small mammals as a model. Chapman and Hall, New York, New York, USA.
Skeel, M. A., and E. Mallory. 1996. Whimbrel, Numenius phaeopus. In A. Poole and F. Gill, editors. The Birds of North America. Number 219. Academy of Natural Sciences, Philadelphia, Pennsylvania, USA, and American Ornithologists' Union, Washington, D.C., USA.

Smith, A. A. 1997. Dispersal and movements in a Swedish Willow Grouse, Lagopus lagopus population. Wildlife Biology 3: 279.

Smith, F. A. 1997. Neotoma cinerea. Mammalian Species 564: $1-8$.

Soderquist, T., and A. Lill. 1995. Natal dispersal and philopatry in the carnivorous marsupial, Phasogale tapoafa (Dasyuridae). Ethology 99: 297-312.

Sokal, R. H., and F. J. Rolf. 1995. Biometry: the principles and practice of statistics in biological research. Freeman, New York, New York, USA.

Southern, H. N. 1970. The natural control of a population of tawny owls (Strix aluco). Journal of the Zoological Society of London 162: 197-285.

Spies, T. A., W. J. Ripple, and G. A. Bradshaw. 1994. Dynamics and patterns of a managed coniferous forest landscape in Oregon. Ecological Applications 4: 555-568.

Sprugel, D. G. 1983. Correcting for bias in log-transformed allometric equations. Ecology 64: 209-210.

Steen, H. 1994. Low survival of long distance dispersers of the root vole (Microtus oeconomus). Annales Zoologica Fennici 31: 271-274.

Storm, G. L., R. D. Andrews, R. L. Phillips, R. A. Bishop, D. B. Siniff, and J. R. Tester. 1976. Morphology, reproduction, dispersal and mortality of midwestern red fox populations. Wildlife Monographs 49: 1-72.

Strickland, D. 1991. Juvenile dispersal in gray jays: dominant brood member expels siblings from natal territory. Canadian Journal of Zoology 69: 2935-2945.

Sullivan, E. G. 1956. Gray fox reproduction, denning, range and weights in Alabama. Journal of Mammalogy 37: 346-351.

Sun, C. 1997. Dispersal of young in red squirrels (Tamiasciurus hudsonicus). American Midland Naturalist 138: $252-259$.

Swihart, R. K. 1992. Home-range attributes and spatial structure of woodchuck populations. Journal of Mammalogy 73: 604-618.

Swingland, I. R. 1982. Intraspecific differences in movement. Pages 32-53 in I. R. Swingland and P. J. Greenwood, editors. The ecology of animal movement. Oxford University Press, Oxford, UK. 
Taylor, R. A. J. 1980. A family of regression equations describing the density distribution of dispersing organisms. Nature 286: 53-55.

Tomlinson, R. E., H. M. Wight, and T. S. Baskett. 1960. Migrational homing, local movement, and mortality of mourning doves in Missouri. Pages 253-267 in Transactions of the 25th North American Wildlife Conference (Dallas, Texas, USA, 1960). Wildlife Management Institute, Washington, D.C., USA.

Turchin, P. 1998. Quantitative analysis of movement: measuring and modeling population redistribution in animals and plants. Sinauer Associates, Sunderland, Massachusetts, USA.

Tweit, R. C. 1996. Curve-billed Thrasher, Toxostoma curvirostre. In A. Poole and F. Gill, editors. The Birds of North America. Number 235. Academy of Natural Sciences, Philadelphia, Pennsylvania, USA, and American Ornithologists' Union, Washington, D.C., USA.

VanCamp, L. F., and C. J. Henny. 1975. The screech owl: its life history and population ecology in northern Ohio. North American Fauna 71: 1-65.

VanDruff, L. W. 1969. Movements of opposums in marsh and wetland habitats. Pages 81-89 in Transactions of Northeast Fish and Wildlife Conference (White Sulphur Springs, West Virginia, USA, 1969). Northeast Section of the Wildlife Society, Amherst, Massachusetts, USA.

Van Vuren, D. 1998. Mammalian dispersal and reserve design. Pages 369-393 in T. Caro, editor. Behavioral ecology and conservation biology. Oxford University Press, New York, New York, USA.

Villard, M.-A., G. Merriam, and B. A. Maurer. 1995. Dynamics in subdivided populations of neotropical migratory birds in a fragmented temperate forest. Ecology 76: $27-40$.

Wallin, K., and M. Andersson. 1981. Adult nomadism in Tengmalm's owl Aegolius funereus. Ornis Scandinavica 12: 125-126.

Waser, P. M. 1987. A model predicting dispersal distance distributions. Pages 251-256 in B. D. Chepko-Sade and Z. T. Halpin, editors. Mammalian dispersal patterns. University of Chicago Press, Chicago, Illinois, USA.

Waser, P. M., S. R. Creel, and J. R. Lucas. 1994. Death and disappearance: estimating mortality risks associated with philopatry and dispersal. Behavioral Ecology 5: 135141.

Waser, P. M., and L. F. Elliott. 1991. Dispersal and genetic structure in kangaroo rats. Evolution 45: 935-943.

Weise, C. M., and J. R. Meyer. 1979. Juvenile dispersal and development of site-fidelity in the Black-capped Chickadee. Auk 96: 40-55.
West, G. B., J. H. Brown, and B. J. Enquist. 1997. A general model for the origin of allometric scaling laws in biology. Science 276: 122-126.

West, S. 1995. Cave Swallow, Hirundo fulva. In A. Poole and F. Gill, editors. The Birds of North America. Number 141. Academy of Natural Sciences, Philadelphia, Pennsylvania, USA, and American Ornithologists' Union, Washington, D.C., USA.

Wheelwright, N. T., and R. A. Mauck. 1998. Philopatry, natal dispersal, and inbreeding avoidance in an island population of Savannah Sparrows. Ecology 79: 755-767.

Whitcomb, R. F., J. F. Lynch, M. K. Klimkiewicz, C. S. Robbins, B. L. Whitcomb, and D. Bystrak. 1981. Effects of forest fragmentation on avifauna of the eastern deciduous forest. Pages 125-206 in R. L. Burgess and D. M. Sharpe, editors. Forest island dynamics in man-dominated landscapes. Springer-Verlag, New York, New York, USA.

Wiklund, C. G. 1996. Determinants of dispersal in breeding merlins (Falco columbarius). Ecology 77: 19201927.

With, K., and T. O. Crist. 1995. Critical thresholds in species' responses to landscape structure. Ecology 76: 24462459.

Wolf, B. O. 1997. Black Phoebe, Sayornis nigricans. In A. Poole and F. Gill, editors. The Birds of North America. Number 268. Academy of Natural Sciences, Philadelphia, Pennsylvania, USA, and American Ornithologists' Union, Washington, D.C., USA.

Wolff, J. O. 1993. What is the role of adults in mammalian juvenile dispersal? Oikos 68: 173-176.

Wolff, J. O., and W. Z. Lidicker, Jr. 1980. Population ecology of the taiga vole, Microtus xanthognathus, in interior Alaska. Canadian Journal of Zoology 58: 18001812.

Woolfenden, G. E., and J. W. Fitzpatrick. 1978. The inheritance of territory in group-breeding birds. BioScience 28: 104-108.

Zimen, E. 1984. Long range movements of the red fox, Vulpes vulpes L. Acta Zoologica Fennici 171: 267. 